\title{
Deprotometalation-Iodolysis and Direct Iodination of 1-Arylated 7-Azaindoles: Reactivity Studies and Molecule Properties
}

\author{
Mohamed Yacine Ameur Messaoud 1,2, Ghenia Bentabed-Ababsa 2,*, Ziad Fajloun 3,4,*iD, Monzer Hamze 5 , \\ Yury S. Halauko ${ }^{6, *}$, Oleg A. Ivashkevich ${ }^{7}$, Vadim E. Matulis ${ }^{7}$, Thierry Roisnel ${ }^{1} \mathbb{D}$, Vincent Dorcet ${ }^{1}$ \\ and Florence Mongin $1, *$ (D)
}

1 Institut des Sciences Chimiques de Rennes-UMR 6226, University of Rennes, CNRS, ISCR, 35000 Rennes, France; m.yacin31@yahoo.fr (M.Y.A.M.); thierry.roisnel@univ-rennes1.fr (T.R.); vincent.dorcet@univ-rennes1.fr (V.D.)

2 Laboratoire de Synthèse Organique Appliquée, Faculté des Sciences Exactes et Appliquées, Université d'Oran 1 Ahmed Ben Bella, BP 1524 El M'Naouer, Oran 31000, Algeria

3 Laboratory of Applied Biotechnology (LBA3B), Azm Center for Research in Biotechnology and Its Applications, EDST, Lebanese University, Tripoli 1300, Lebanon

4 Faculty of Sciences 3, Campus Michel Slayman, Lebanese University, Tripoli 1352, Lebanon

5 Laboratoire Microbiologie, Santé et Environnement, Doctoral School of Sciences and Technology,

check for updates

Citation: Ameur Messaoud, M.Y.; Bentabed-Ababsa, G.; Fajloun, Z; Hamze, M.; Halauko, Y.S.; Ivashkevich, O.A.; Matulis, V.E.; Roisnel, T.; Dorcet, V.; Mongin, F. Deprotometalation-Iodolysis and Direct Iodination of 1-Arylated

7-Azaindoles: Reactivity Studies and Molecule Properties. Molecules 2021, 26, 6314. https://doi.org/10.3390/ molecules 26206314

Academic Editors: Pascale Moreau and Nuria Sotomayor

Received: 17 September 2021

Accepted: 15 October 2021

Published: 19 October 2021

Publisher's Note: MDPI stays neutral with regard to jurisdictional claims in published maps and institutional affiliations.

Copyright: (c) 2021 by the authors. Licensee MDPI, Basel, Switzerland. This article is an open access article distributed under the terms and conditions of the Creative Commons Attribution (CC BY) license (https:// creativecommons.org/licenses/by/ $4.0 /)$.
Faculty of Public Health, Lebanese University, Tripoli 1300, Lebanon; mhamze@monzerhamze.com

6 UNESCO Chair of Belarusian State University, 220030 Minsk, Belarus

7 Research Institute for Physico-Chemical Problems, Belarusian State University, 220030 Minsk, Belarus; fhp@bsu.by (O.A.I.); matulisvad@bsu.by (V.E.M.)

* Correspondence: bentabedg@gmail.com (G.B.-A.); ziad.fajloun@ul.edu.lb (Z.F.); hys@tut.by (Y.S.H.); florence.mongin@univ-rennes1.fr (F.M.)

\begin{abstract}
Five protocols were first compared for the copper-catalyzed C-N bond formation between 7 -azaindole and aryl/heteroaryl iodides/bromides. The 1-arylated 7-azaindoles thus obtained were subjected to deprotometalation-iodolysis sequences using lithium 2,2,6,6-tetramethylpiperidide as the base and the corresponding zinc diamide as an in situ trap. The reactivity of the substrate was discussed in light of the calculated atomic charges and the $\mathrm{p} K_{\mathrm{a}}$ values. The behavior of the 1-arylated 7-azaindoles in direct iodination was then studied, and the results explained by considering the HOMO orbital coefficients and the atomic charges. Finally, some of the iodides generated, generally original, were involved in the $N$-arylation of indole. While crystallographic data were collected for fifteen of the synthesized compounds, biological properties (antimicrobial, antifungal and antioxidant activity) were evaluated for others.
\end{abstract}

Keywords: 7-azaindole; deprotometalation; iodination; regioselectivity; $\mathrm{N}$-arylation

\section{Introduction}

Due to its similarity with indole and purine, $1 H$-pyrrolo[2,3-b] pyridine (7-azaindole) has aroused the interest of the chemical community [1-8], for example, for medicinal applications, as this motif can be found in molecules with of a broad spectrum of bioactivities. Mention may be made, for example, of compounds used to treat diseases involving the abnormal regulation of enzymes.

Among them, variolin B and certain meriolins are, respectively, good inhibitors of casein and cyclin-dependent kinases and therefore promising for the treatment of brain cancers (Figure 1, left) [9,10]. Also based on a 7-azaindole, GSK 1070916 is a potent inhibitor of Aurora kinases, which are involved in the regulation of mitosis and frequently overexpressed in cancer tumors (Figure 1, right) [11]. 


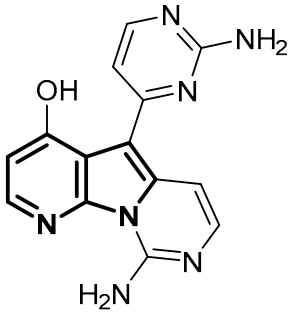

variolin $B$

$\mathrm{IC}_{50}(\mathrm{CK} 1)=5 \mathrm{nM}$

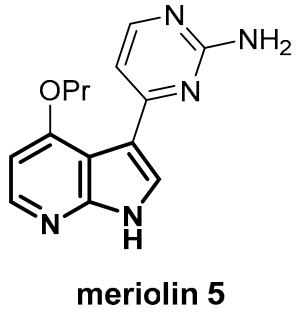

$\mathrm{IC}_{50}(\mathrm{CDK} 1)=7 \mathrm{nM}$

$\mathrm{IC}_{50}(\mathrm{CDK} 2)=3 \mathrm{nM}$

$\mathrm{IC}_{50}(\mathrm{CDK} 5)=3 \mathrm{nM}$

$\mathrm{IC}_{50}(\mathrm{CDK} 9)=6 \mathrm{nM}$

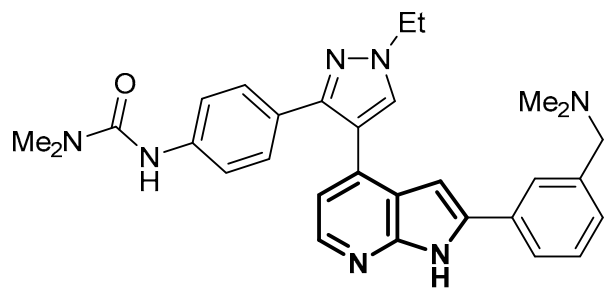

GSK 1070916

$\mathrm{IC}_{50}$ (Aurora B) $=3.5 \mathrm{nM}$

$\mathrm{IC}_{50}$ (Aurora $\left.\mathrm{C}\right)=6.5 \mathrm{nM}$

Figure 1. Compounds of biological interest containing a 7-azaindole core and their bioactivities.

7-Azaindole can also be present in the backbone of organic materials, for example exhibiting luminescence properties. Furthermore, due to the nucleophilicity of pyridine nitrogen, 7-azaindole derivatives can also act as ligands for catalysis [12].

While much work has been devoted to the functionalization of 7-azaindole, relatively little of it deals with the functionalization of the azaindole ring of 1-arylated derivatives. Dong and coworkers published studies in 2015-2016 in which tetracycles were formed from 1-aryl-7-azaindoles and diphenylacetylene by a rhodium(III)-catalyzed annulation reactions $[13,14]$. In 2016, tetracyclic heterocycles were also built by Ge, Li and coworkers from 1-arylated 7-azaindoles by using as a key step the rhodium(III)-catalyzed C-H oxidative olefination of the aryl group [15]. A year later, Mishra, Kim and coworkers converted a 1-arylated 7-azaindole to azaindoloquinoline by rhodium(III)-catalyzed C-H amination followed by intramolecular cyclization [16]. Metal-free functionalization of 1-arylated 7 -azaindoles is also possible, as evidenced by the work of Xu, Dong and coworkers; in this case, another type of tetracyclic heterocycle was synthesized by TsOH-induced tandem [3+2] cyclization between 7-azaindoles and pyridotriazoles [17].

Our objective in the present study was to develop methods to introduce an iodine atom either at the 2- or at the 3-position of 1-aryl-7-azaindoles and to predict the outcome of these reactions $[18,19]$ using $\mathrm{p} K_{\mathrm{a}}$, atomic charges and HOMO orbital coefficients.

\section{Results and Discussion}

\subsection{1-Arylation of 7-Azaindole}

Due to our interest in the copper-catalyzed $\mathrm{N}$-arylation of azoles with aryl or heteroaryl iodides [20-25], access to the required 1-arylated 7-azaindoles was considered in this way.

Various protocols using copper-based catalysts have already been reported to 1-arylate 7 -azaindole with aryl or heteroaryl halides $[3,5,26]$. As part of this study, we decided to compare five sets of conditions already used to $N$-arylate azoles with aryl/heteroaryl iodides or bromides. We chose (i) the simple 'ligand-free' copper-catalyzed $\mathrm{N}$-arylation of azoles documented by $\mathrm{Hu}$ and coworkers (Method $\mathrm{A}$ : $\mathrm{Cu}\left(0.2\right.$ equiv), $\mathrm{Cs}_{2} \mathrm{CO}_{3}$ (2 equiv), acetonitrile at reflux) [27]; (ii) the lithium chloride-mediated copper(I) iodide-catalyzed 1-arylation of azaindoles reported by Yum and coworkers (Method B: CuI (0.1 equiv), $\mathrm{K}_{2} \mathrm{CO}_{3}$ (3 equiv), $\mathrm{LiCl}$ (1 equiv), dimethylformamide (DMF) at $120^{\circ} \mathrm{C}$ ) [28]; (iii) the copperdiamine method developed by Buchwald and coworkers to $\mathrm{N}$-arylate azoles (Method $\mathrm{C}$ : $\mathrm{CuI}(5 \mathrm{~mol} \%), \mathrm{K}_{3} \mathrm{PO}_{4}$ (2 equiv), $N, N^{\prime}$-dimethylethylenediamine (DMEDA; 0.1 equiv), DMF at reflux) [29]; (iv) the protocol Teo and coworkers used to $\mathrm{N}$-arylate azoles, including 7-azaindole, with iodopyridines (Method $D$ : $\mathrm{Cu}_{2} \mathrm{O}$ (0.1 equiv), $\mathrm{Cs}_{2} \mathrm{CO}_{3}$ (2 equiv), dimethylsulfoxide (DMSO) at $110^{\circ} \mathrm{C}$ ) [30]; and (v) the 'ligand-free' procedure Yum and coworkers employed to $\mathrm{N}$-arylate carbazole under microwave irradiation (Method $\mathrm{E}$ : $\mathrm{CuI}$ (0.1 equiv), $\mathrm{Cs}_{2} \mathrm{CO}_{3}$ (1 equiv), DMF, MWI at $350 \mathrm{~W}$ ) [31].

The results are shown in Table 1. The reactions performed from iodobenzene (entries 1-5) and 4-iodoanisole (entries 6-10) were more efficiently carried out with methods using a ligand (DMEDA for Method C, or DMSO for Method D). Therefore, we applied them to 
1-arylate 7-azaindole with 1-chloro-4-iodobenzene (entry 11), 1-fluoro-4-iodobenzene (entry 12), 1-iodo-4-(trifluoromethyl)benzene (entries 13 and 14), 1-iodo-3,5-dimethylbenzene (entry 15), 2-iodothiophene (entries 16 and 17), 3-iodopyridine (entries 18 and 19), 2bromopyridine (entries 20 and 21) and 4-bromopyridine (entry 22). Method D worked well with all tested iodides but was less effective with bromides. Method $C$ appeared to be a higher-yielding protocol, whether for the iodides tested or for 2-bromopyridine; this is not surprising since this method has been shown to be effective for substrates known to be reluctant to $N$-arylation such as iodoferrocenes [32,33].

Table 1. 1-Arylation of 7-azaindole by using methods reported for the $N$-arylation of azoles.

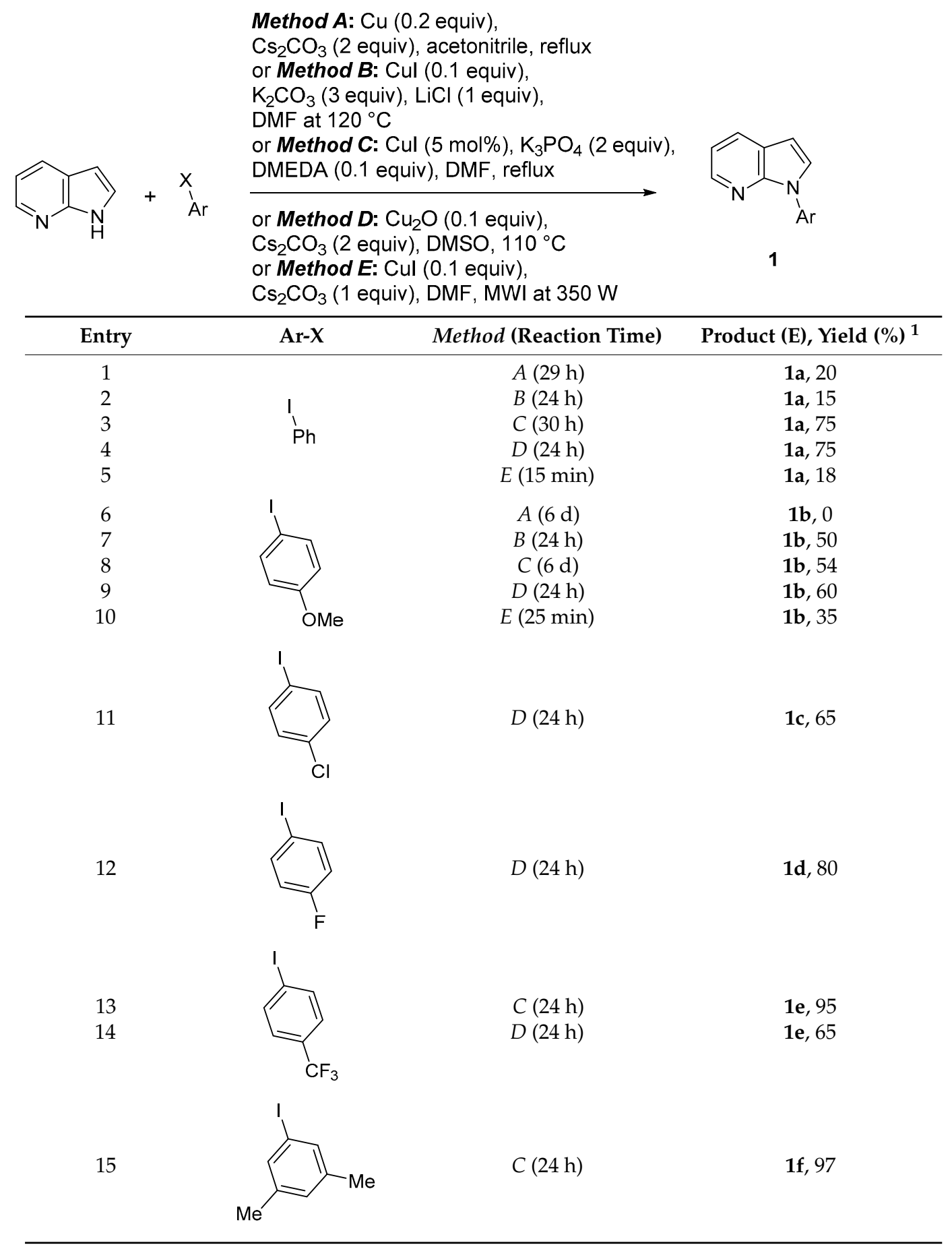


Table 1. Cont.

\begin{tabular}{|c|c|c|c|}
\hline Entry & Ar-X & Method (Reaction Time) & Product (E), Yield (\%) ${ }^{1}$ \\
\hline $\begin{array}{l}16 \\
17\end{array}$ & & $\begin{array}{l}B(24 \mathrm{~h}) \\
C(48 \mathrm{~h})\end{array}$ & $\begin{array}{l}1 g, 37 \\
1 g, 92\end{array}$ \\
\hline $\begin{array}{l}18 \\
19\end{array}$ & & $\begin{array}{l}C(48 \mathrm{~h}) \\
D(24 \mathrm{~h})\end{array}$ & $\begin{array}{l}\text { 1h, } 80 \\
\text { 1h, } 80\end{array}$ \\
\hline $\begin{array}{l}20 \\
21\end{array}$ & & $\begin{array}{l}C(48 \mathrm{~h}) \\
D(24 \mathrm{~h})\end{array}$ & $\begin{array}{l}\mathbf{1 i}, 75 \\
\mathbf{1 i}, 35\end{array}$ \\
\hline 22 & & $D(24 \mathrm{~h})$ & $\mathbf{1 j}, 35$ \\
\hline
\end{tabular}

$\overline{{ }^{1} \text { After purification (see experimental part); when low yields were recorded, starting materials were in general recovered. }}$

Concerning the double $N$-arylation reaction between 7-azaindole and 1,3-diiodobenzene, Method C also provided the expected product $\mathbf{2 k}$ with a higher yield ( $40 \%$ ) than Method D (15\%). However, despite long reaction times of $4-5$ days, the product $\mathbf{2} \mathbf{k}^{\prime}$ resulting from a single $N$-arylation is still present (isolated in $20 \%$ yield in both cases) (Scheme 1 , top). By contrast, when Method $C$ was applied to the reaction between 7 -azaindole and 1,4diiodobenzene, the expected product 21 was this time obtained with a high $80 \%$ yield (Scheme 1, bottom).<smiles>Ic1cccc(I)c1</smiles>

Method C:

Cul $(5 \mathrm{~mol} \%)$

$\mathrm{K}_{3} \mathrm{PO}_{4}$ (2 equiv),

$\operatorname{DMEDA}(0.1$ equiv)

DMF, reflux, $4 \mathrm{~d}$

Method D:

$\mathrm{Cu}_{2} \mathrm{O}$ (0.1 equiv),

$\mathrm{Cs}_{2} \mathrm{CO}_{3}$ (2 equiv)

DMSO, $100^{\circ} \mathrm{C}, 5 \mathrm{~d}$

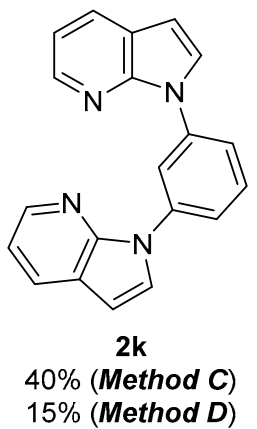<smiles>Ic1cccc(-n2ccc3cccnc32)c1</smiles>

15\% (Method D) 20\% (Method D)<smiles>Ic1ccc(I)cc1</smiles>

Method C:

Cul $(5 \mathrm{~mol} \%)$

$\mathrm{K}_{3} \mathrm{PO}_{4}$ (2 equiv),

DMEDA ( 0.1 equiv)

DMF, reflux, $3 \mathrm{~d}$

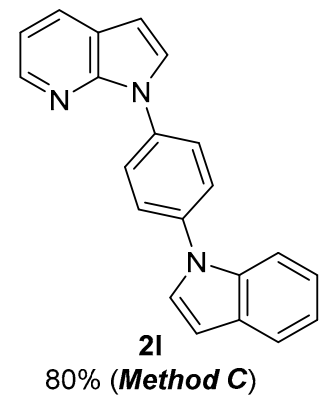

Scheme 1. 1-Arylation reactions between 7-azaindole and 1,3- or 1,4-diodobenzene.

The compounds $\mathbf{1 e}, \mathbf{1} \mathbf{i}, \mathbf{1} \mathbf{j}, \mathbf{2} \mathbf{k}$ and $\mathbf{2} \mathbf{l}$ were unambiguously identified by X-ray diffraction (Figure 2). Due to steric hindrance, their two or three rings have not been shown to be coplanar. While the torsion angles were at most $25^{\circ}$ in the case of $1 \mathbf{e}\left(25.1^{\circ}\right), \mathbf{1 i}\left(2.3 / 10.9^{\circ}\right)$, 
$\mathbf{1 j}\left(14.2^{\circ}\right)$ and $2 \mathbf{l}\left(25.0^{\circ}\right.$ and $\left.25.0^{\circ}\right)$, a higher value was observed for $2 \mathbf{k}\left(22.7^{\circ}\right.$ and $\left.35.8^{\circ}\right)$. This could explain why lower yields were noticed for $\mathbf{2 k}$ compared to $\mathbf{2 1}$.

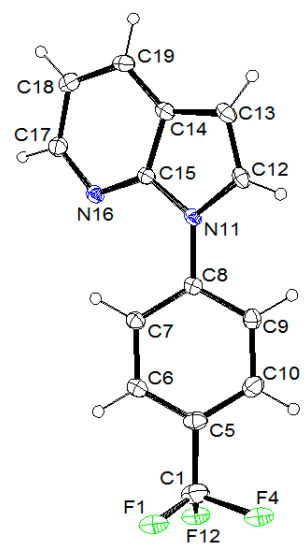

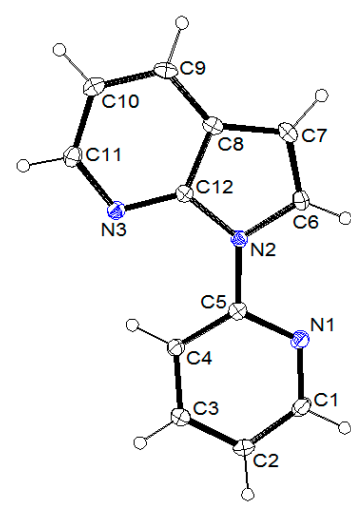

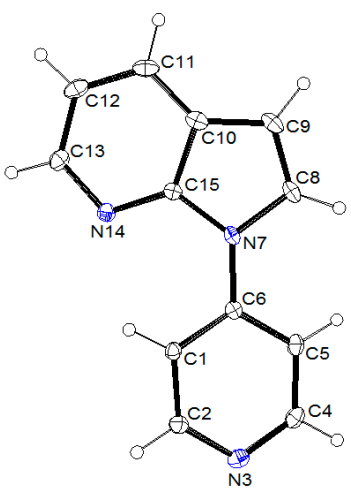
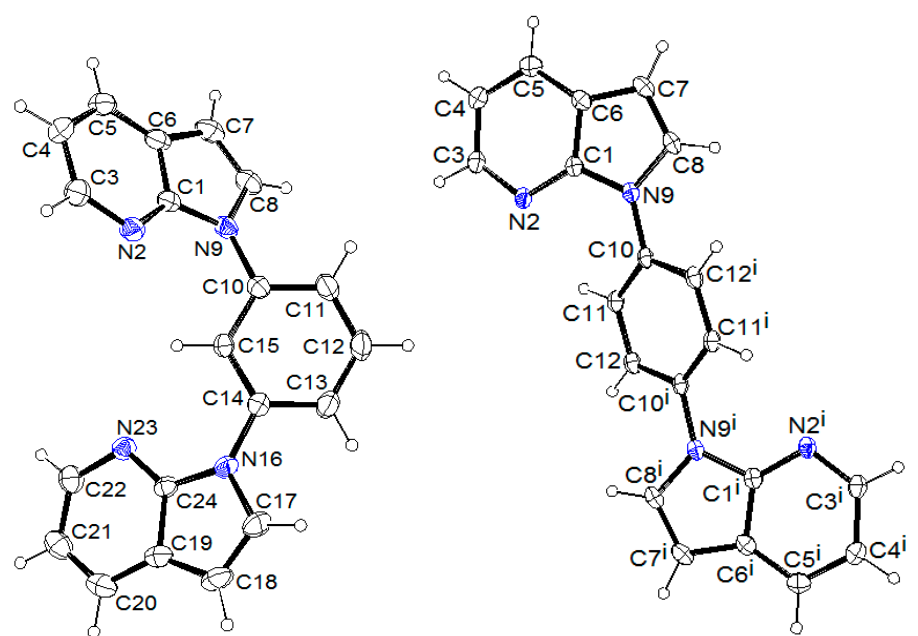

Figure 2. ORTEP diagrams (30\% probability) of $\mathbf{1 e}, \mathbf{1} \mathbf{i}, \mathbf{1} \mathbf{j}, \mathbf{2} \mathbf{k}$ and $\mathbf{2 1 .}$

The X-ray diffraction data recorded for the compounds $1 \mathbf{e}$ and $\mathbf{1 i}$ deserve some additional comments. In the case of $\mathbf{1 e}$, short intermolecular contacts were observed at the solid state between the pyridine nitrogen of azaindole and the hydrogen at $\mathrm{C} 3$ (2.644 $\AA$ ), causing a linear chain, while a fluorine of the trifluoromethyl group is close to the hydrogens of two different azaindoles of another chain, one at $C 4(2.651 \AA)$ and the other at C6 (2.625 $\AA$ ) (Figure $3 \mathrm{~A})$. In the case of $1 \mathbf{i}$, the molecules are arranged in pairs of two parallel azaindoles (separated by about $3.3 \AA$ ); these pairs are connected by short contacts between the pyridine nitrogen of the azaindole of one pair and the hydrogen at $\mathrm{C} 3$ of the azaindole of another pair (2.609 $\AA$ ) (Figure 3B). Overall, the XRD geometries are very close to those predicted by DFT calculations (see Supplementary Materials), including the most stable rotamer form. 


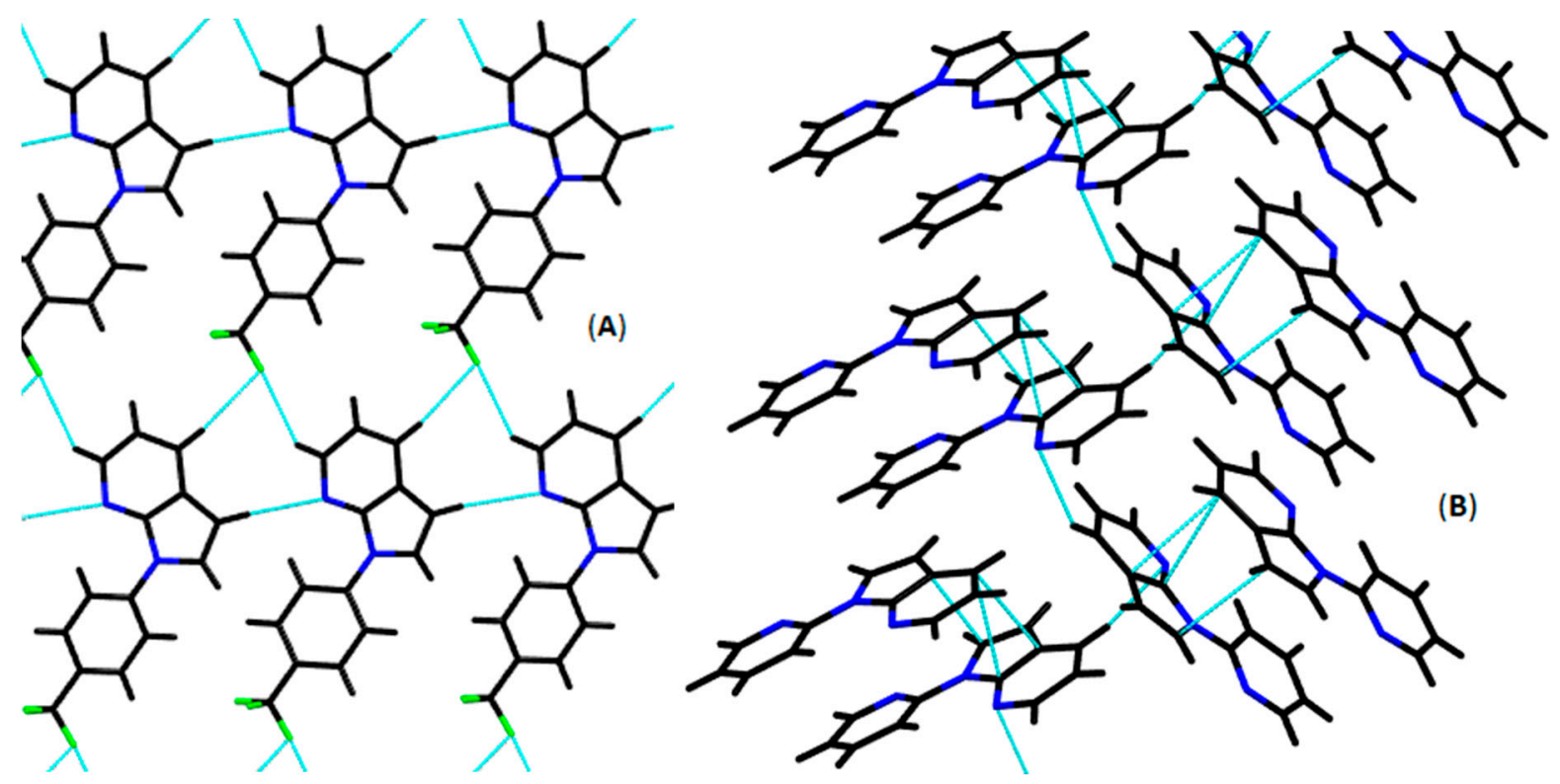

Figure 3. Short-contact networks observed for 1e (A) and 1i (B).

\subsection{Deprotometalation-Iodolysis of 1-Arylated 7-Azaindoles}

Deprotolithiation-trapping sequences at the 2-position of 7-azaindoles have largely been developed after protection of the NH [3]. In 1997, Mérour and coworkers reported the first studies on the topic from the 1-phenylsulfonyl derivative; the key deprotolithiation step was carried out by using lithium diisopropylamide (2 equiv) in tetrahydrofuran (THF) at $-25^{\circ} \mathrm{C}$ for $0.5 \mathrm{~h}$ and was evidenced by subsequent trapping with various electrophiles [34]. However, probably because the sulfonamide function also activates the phenyl group [35], a second deprotonation at the phenyl ring was noticed with electrophiles such as chlorotrimethylsilane and chlorotrimethylstannane which are known for their greater compatibility with hindered lithium amides. In 2007, Kondo and coworkers identified mesityllithium as an alternative base to the lithium amide for similar substrates [36].

One way to deprotometalate the 2-position without protection/deprotection steps is to form a carbamate in situ. In 1999, Curtis and coworkers extended this approach, first developed in the indole series by Katritzky and coworkers [37], to 7-azaindole. They successively treated 7-azaindole with $n$-butyllithium and carbon dioxide before performing C2-deprotolithiation with tert-butyllithium in THF at $-78{ }^{\circ} \mathrm{C}$, subsequent electrophilic trapping $\left(\mathrm{CO}_{2}\right)$ and acidic treatment; under these conditions, the carboxylic acid was obtained with a correct yield [38].

The 7-azaindoles 1-substituted by methyl, diethylaminomethyl and methoxymethyl groups can also be functionalized at their 2-position after deprotolithiation using tertbutyllithium in THF (addition of the base at $-78{ }^{\circ} \mathrm{C}$ before warming to $0{ }^{\circ} \mathrm{C}$ ). This was evidenced in 2008 by $\mathrm{O}^{\prime}$ Shea, Tacke and coworkers who successfully employed 6(dimethylamino)fulvene as an electrophile [39]. It is worth noting that 2-(trimethylsilyl)etho xymethyl can also be employed as a protecting group to easily deprotonate the adjacent site [40,41]. As might be expected, when tri(isopropyl)silyl is present on 7-azaindole N1, the 5-membered ring is protected from deprotometalation [42].

In the absence of a substituent at N1, it is possible to reroute the reaction on the pyridine ring by benefiting from an anionic shielding in situ, thanks to an efficient directing group (such as $\mathrm{N}, \mathrm{N}$-diethylcarboxamide or $\mathrm{N}, \mathrm{N}$-diethylsulfonamide) at the 3- and possibly 4-position. This was demonstrated by Snieckus and coworkers in 2012 [43]. The same group more recently identified $N, N$-diisopropylcarboxamide as a directing group for the introduction of different substituents at $\mathrm{C} 2$ after deprotolithiation using lithium diisopropylamide ( 2 equiv) in THF at $-78{ }^{\circ} \mathrm{C}$. An elegant dance of directed metalation-groups was 
also developed by the same authors to successively functionalize the 6 (directing group onto the N7 nitrogen) and 2 (directing group onto the N1 nitrogen) positions [44].

To our knowledge, the only 1-aryl-7-azaindole already involved in deprotolithiationtrapping is 1-(2-pyridyl)-7-azaindole. Wang and coworkers introduced a deuterium or a methyl group at its 2-position by reaction with lithium diisopropylamide (2.5 equiv) in diethyl ether at $-78{ }^{\circ} \mathrm{C}$ for $40 \mathrm{~min}$ and subsequent trapping with heavy water or iodomethane, respectively [45]. Our goal in this part is to evaluate the scope of the deprotometalation of 1-aryl-7-azaindoles by using as substrates the compounds $\mathbf{1}$ described above. We used a common electrophile in order to easily compare the reactivities of our substrates, and we chose iodine since it is possible to take advantage of this heavy halogen to carry out postfunctionalizations such as Suzuki-Miyaura [3,46], Sonogashira [3] or even Heck [3] couplings.

Previous results from the group showed that 1-phenylindole could be efficiently deprotonated at $\mathrm{C} 2$ by using a base prepared from $\mathrm{ZnCl}_{2}$. TMEDA (TMEDA $=N, N, N^{\prime}, N^{\prime}$ tetramethylethylenediamine) and LiTMP (TMP $=2,2,6,6$-tetramethylpiperidino) in a 1:3 ratio [47-49]. Indeed, after treatment of the substrate by this formed 1:1 LiTMP-Zn(TMP) ${ }_{2}$ mixture of amides $[47,50,51]$ in THF at room temperature (rt) and addition of iodine to intercept the heteroarylmetal obtained, 2-iodo-1-phenylindole was isolated with a yield of $92 \%$ [52]. Under these conditions, it is accepted that LiTMP deprotolithiates the heterocycle and that the heteroaryllithium is then trapped by a zinc species through transmetalation $[47,50,51]$. The calculated hydrogen atomic charges ( $\mathrm{H}$ charges) and $\mathrm{C}-\mathrm{H} \mathrm{pK}$ values [52] of 1-phenylindole (Figure 4A) are in good agreement with the observed results, with both the most positive hydrogen and the most stabilized lithiated compound at C2.
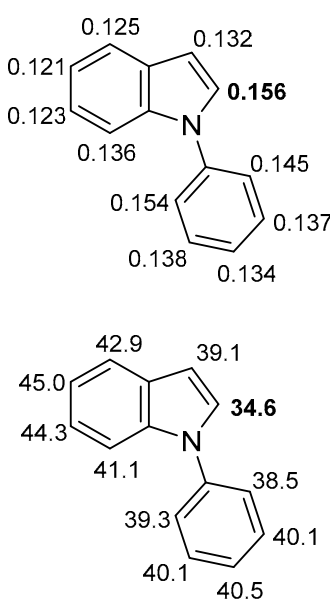

(A)
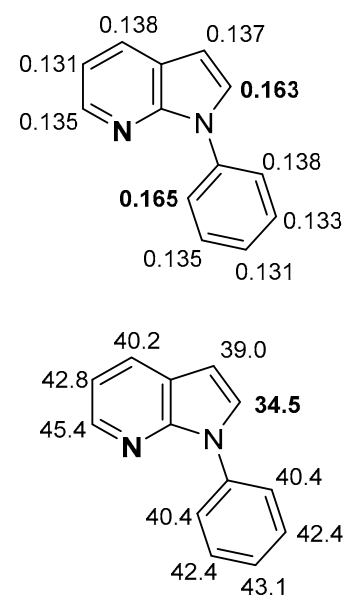

(B)
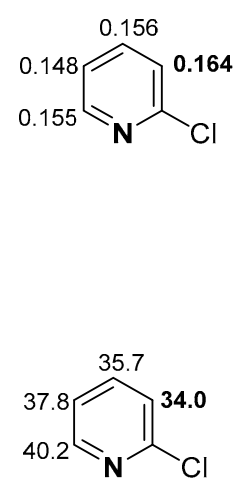

(C)

Figure 4. Calculated $\mathrm{H}$ charges (top) and $\mathrm{p} K_{\mathrm{a}}$ values (bottom) of 1-phenylindole [52] (A), 1-phenyl-7azaindole (1a; B) and 2-chloropyridine [53] (C).

To our knowledge, the acidic properties of 7-azaindoles have not yet been investigated. The most related experimental study is that of Fraser and coworkers [54], who determined the $\mathrm{p} K_{\mathrm{a}}$ values in THF of five-membered heteroaromatic C-H acids, including $\mathrm{N}$-methylindole. In 2014-2015, we also computed the $\mathrm{p} K_{\mathrm{a}}$ values of $\mathrm{N}$-arylated pyrroles and indoles [52] as well as 1-arylated benzotriazoles and indazoles [55] by using DFT.

In general (except for $\mathrm{C} 5$ and $\mathrm{C} 6$ which are reversed), the $\mathrm{p} K_{\mathrm{a}}$ distribution pattern of 1-aryl-7-azaindoles resembles that of 1-arylindoles [52]. In the case of 1-phenyl-7azaindole (1a), the most positively charged hydrogens are located at phenyl C2' (opposite to the pyridine nitrogen in bold) and azaindole $\mathrm{C} 2$ (next to the pyrrole nitrogen) while the most stabilized lithiated derivative is also at $\mathrm{C} 2$ (Figure 4B). It is interesting to know which of the lithiated intermediates is intercepted by $\mathrm{Zn}(\mathrm{TMP})_{2}$ during such a LiTMPmediated deprotonation. 
For this purpose, 1a was treated at $\mathrm{rt}$ for $2 \mathrm{~h}$ by the basic combination prepared in situ in THF from $\mathrm{ZnCl}_{2} \cdot$ TMEDA (1 equiv) and LiTMP ( 3 equiv), and iodine was added to quench the organometallic intermediate. Under these conditions, the 2-iodinated derivative 3a was isolated with a yield of $75 \%$ (Table 2, entry 1). This can result either from direct deprotolithiation at $\mathrm{C} 2$ or from deprotonation at another position (directed by the pyridine nitrogen) followed by isomerization, before transmetalation to a zinc species. This situation could parallel that of 2-chloropyridine for which the kinetic lithiated product is at C6 (due to the presence of a neighboring coordinating pyridine nitrogen) and the thermodynamic product at $\mathrm{C} 3$ (both highest $\mathrm{H}$ charge and lower $\mathrm{p} K_{\mathrm{a}}$ value [53]) [56] (Figure 4C).

Table 2. Deprotometalation of the 1-arylated 7-azaindoles followed by iodolysis.
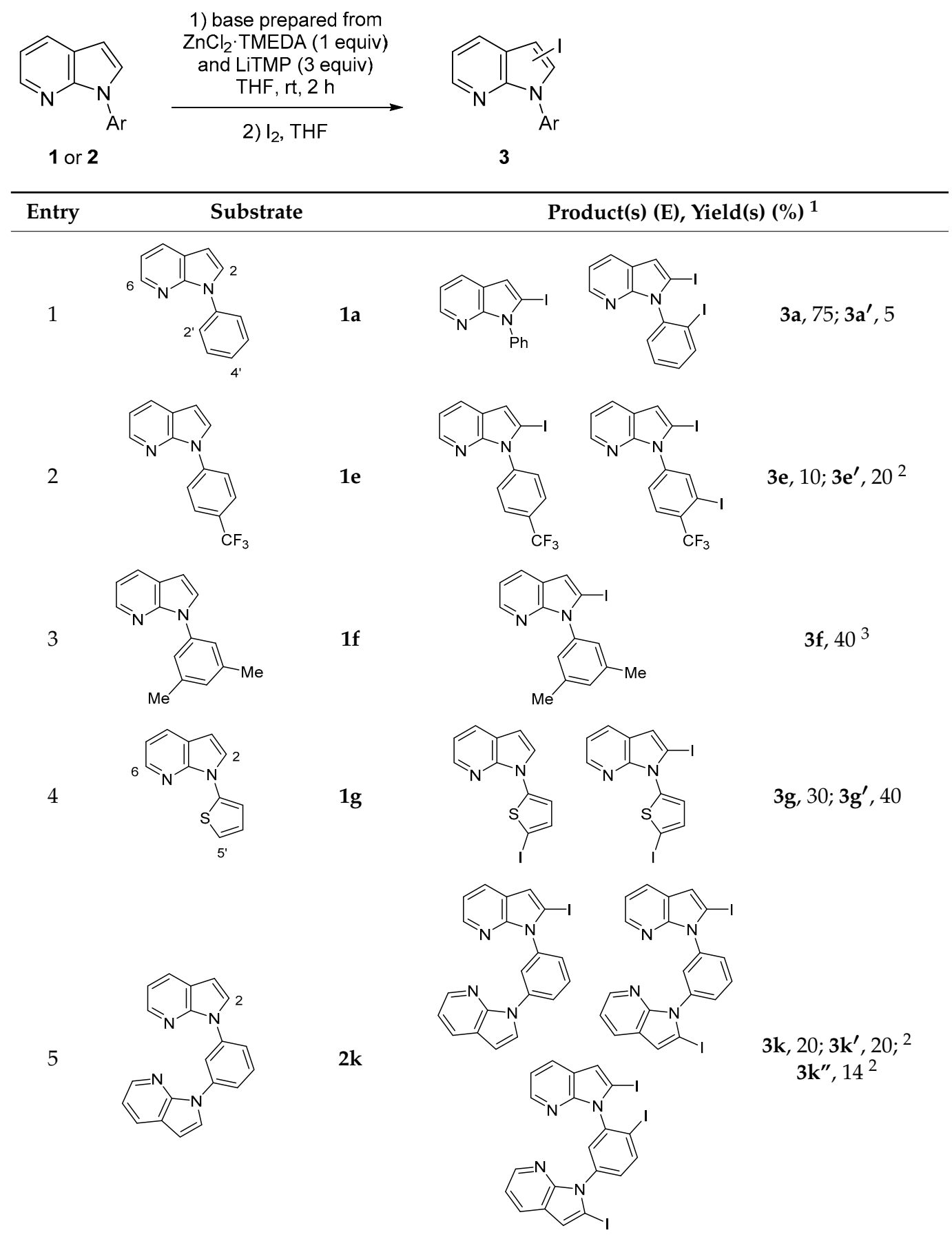

${ }^{1}$ After purification (see experimental part). ${ }^{2}$ Low yields were obtained, due to difficult separation. ${ }^{3}$ The rest was $\mathbf{1 f}$. 
When a substituent such as $\mathrm{OMe}$ and especially $\mathrm{CF}_{3}$ is present at the 4-position of the phenyl, the hydrogens at $\mathrm{C}^{\prime}$ still compete with those at $\mathrm{C} 2$ to be the most positively charged, but this time the $\mathrm{p} K_{\mathrm{a}}$ values are lowered at the remaining free sites of the phenyl (Figure 5A,B). Consequently, other aryllithiums could be formed and intercepted by $\mathrm{Zn}(\mathrm{TMP})_{2}$ before isomerization to 2-(7-azaindolyl)lithium. It is therefore no surprise that inseparable mixtures coming from deprotonations at $\mathrm{C} 2$ and at the 4-methoxyphenyl were obtained from $\mathbf{1 b}$ under these conditions (not shown). In the case of $\mathbf{1 e}$, both the 2-iodinated derivative $3 \mathbf{e}$ and the $2,3^{\prime}$-diiodinated derivative $3 \mathbf{e}^{\prime}$ were obtained (in yields of 10 and $20 \%$, respectively) from such a complex mixture (Table 2, entry 2); this could result from a second deprotonation at the phenyl of the 2-(7-azaindolyl)zinc species [57]. By contrast, from 1-(3,5-dimethylphenyl)-7-azaindole (1f), no competitive reaction on the phenyl ring took place, as expected from the calculated $\mathrm{p} K_{\mathrm{a}}$ values (Figure $5 \mathrm{C}$ ); the only 2 -iodinated derivative $3 \mathbf{f}$ was isolated with a yield of $40 \%$ (Table 2, entry 3).
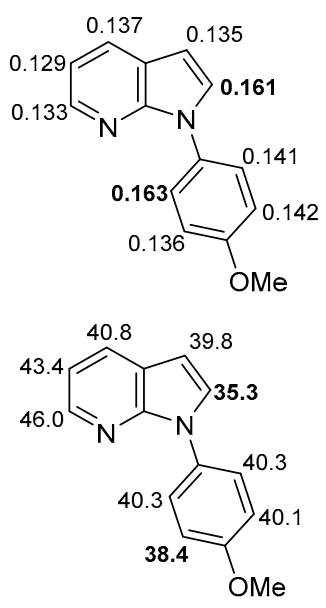

(A)

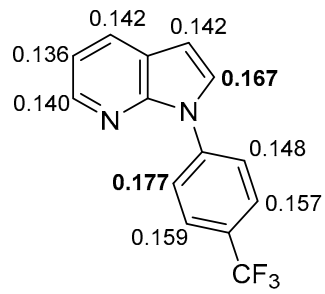<smiles></smiles>

(B)<smiles>Cc1cc(C)cc(-n2c([14O])cc3cc([O-])ncc32)c1</smiles><smiles>Cc1cc(C)cc(-n2nc3cc([As])ccc3c2Br)c1</smiles>

(C)

Figure 5. Calculated $H$ charges (top) and $\mathrm{p} K_{\mathrm{a}}$ values (bottom) of 1-(4-methoxyphenyl)-7-azaindole (1b; $\left.\mathbf{A}\right)$, 1-(4-(trifluoromethyl)phenyl)-7-azaindole (1e; B) and 1-(3,5-dimethylphenyl)-7-azaindole (1f; C).

As indicated by the corresponding $\mathrm{p} K_{\mathrm{a}}$ values, 2-thienylmetals are easier to obtain due to their greater stability than, for example, phenylmetals (Figure 6A). Therefore, when subjected to our lithium-zinc basic combination prior to iodolysis, $\mathbf{1 g}$ did not lead to the 2-iodinated product. Instead, 1-(5-iodo-2-thienyl)-7-azaindole (3g; isolated in 30\% yield) and the diiodinated derivative $3 \mathbf{g}^{\prime}$ (40\% yield) were formed (Table 2, entry 4 ). Again, due to similar $\mathrm{p} K_{\mathrm{a}}$ values (Figure 6B) or a proximity effect [57], a mixture of the three products $3 \mathbf{k}$, $\mathbf{3} \mathbf{k}^{\prime}$ and $\mathbf{3} \mathbf{k}^{\prime \prime}$ was obtained when $\mathbf{2} \mathbf{k}$ was processed in the same reaction conditions (Table 2, entry 5).
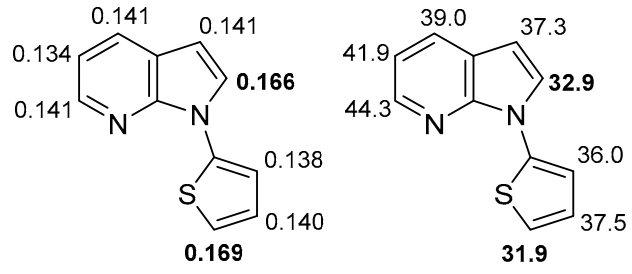

(A)

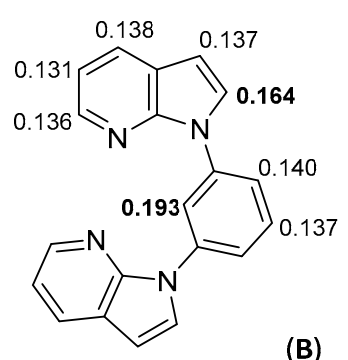

(B)

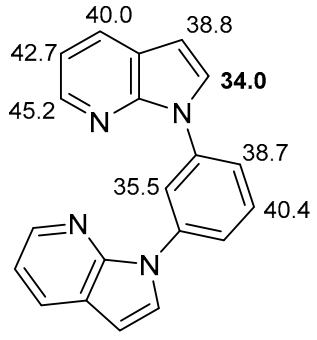

Figure 6. Calculated $\mathrm{H}$ charges and $\mathrm{p} K_{\mathrm{a}}$ values of 1-(2-thienyl)-7-azaindole $(\mathbf{1 g} ; \mathbf{A})$ and 1,1'-(1,3-phenylene)bis(7azaindole) (2k; B). 
Thus, by calculating the $\mathrm{p} K_{\mathrm{a}}$ values of these 1-aryl-7-azaindoles, it is quite easy to predict whether the reaction leads to a main iodinated derivative or whether mixtures are expected.

Among the X-ray diffraction data collected to unambiguously assign a structure to the isolated products (Figure 7), a few elements are noticeable. Halogen bonds [58] between pyridine nitrogen and iodine at C2 (2.932 $\AA$ ) have been identified at the solid state in the case of $\mathbf{3} \mathbf{a}^{\prime}$ whereas they do not exist for the monoiodide $\mathbf{3 a}$ (Figure 8A). Moreover, an intramolecular chalcogen bond [59] between pyridine nitrogen and thiophene sulfur $(2.962 \AA$ ) exists for $3 g$ (Figure $8 \mathrm{~B})$. Finally, short contacts were observed in the case of $3 \mathbf{g}^{\prime}$, between thiophene iodines (3.948 $\AA$ ), as well as between iodine at C2 and thiophene iodine-bearing carbon (3.633 $\AA$ ) (Figure 8C).

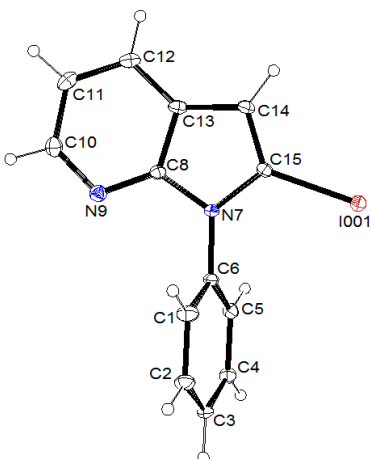

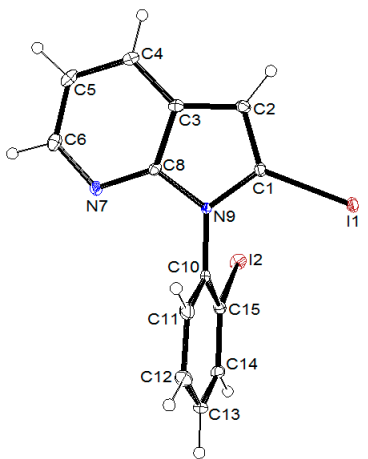

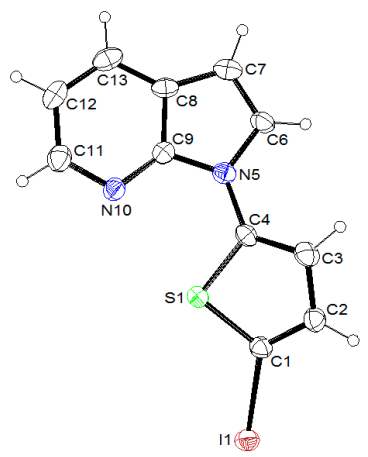

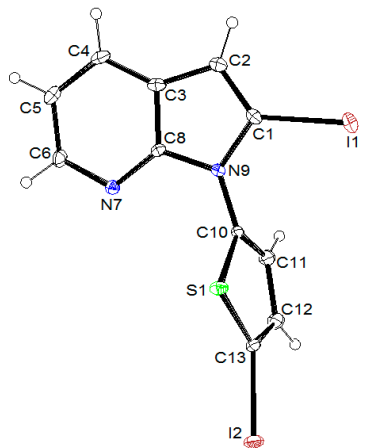

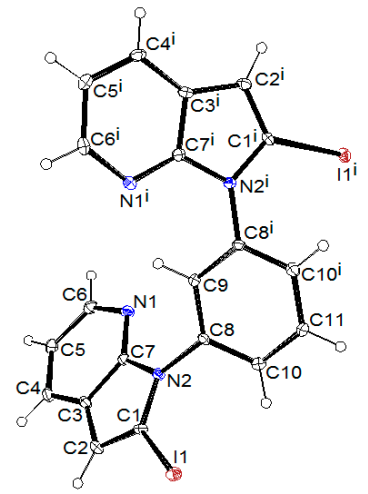

Figure 7. ORTEP diagrams (30\% probability) of $\mathbf{3 a}, \mathbf{3} \mathbf{a}^{\prime}, \mathbf{3} \mathbf{g}, \mathbf{3} \mathbf{g}^{\prime}$ and $\mathbf{3} \mathbf{k}^{\prime}$.

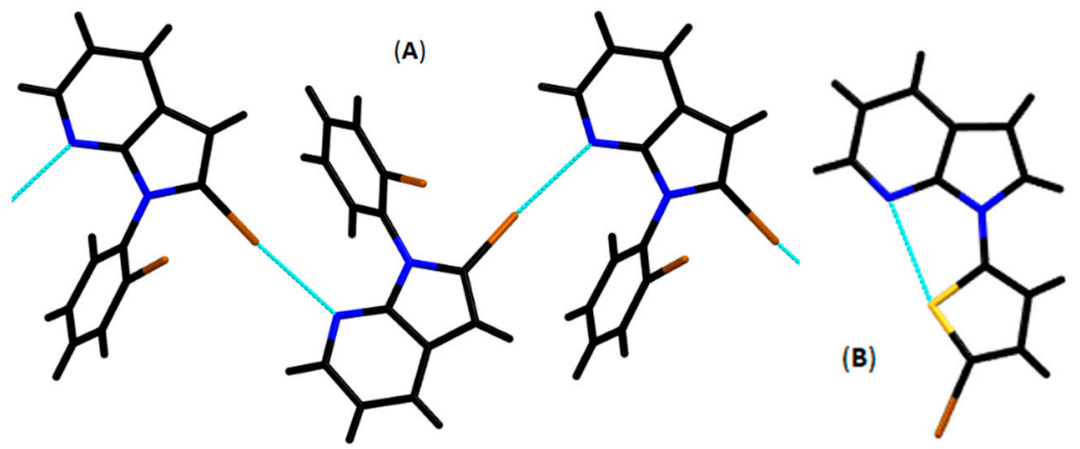

Figure 8. Cont. 


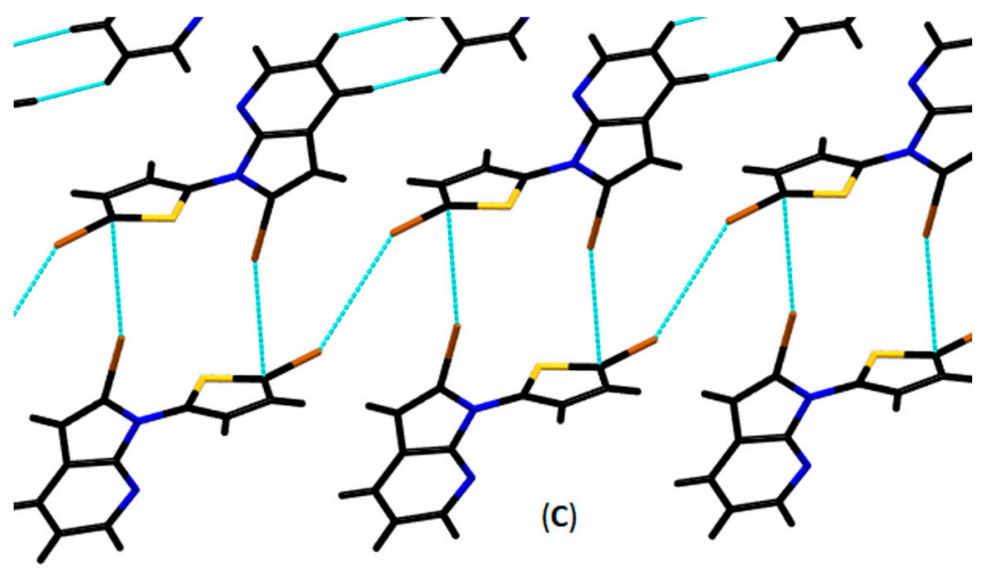

Figure 8. Halogen and chalcogen bond networks observed for $\mathbf{3} \mathbf{a}^{\prime}(\mathbf{A})$ and $\mathbf{3 g}(\mathbf{B})$, respectively; short contact involving iodine atoms for $3 \mathbf{g}^{\prime}(\mathbf{C})$.

\subsection{Direct Iodination of 1-Arylated 7-Azaindoles}

The incorporation of iodine atoms at the 3-position of 7-azaindole can be used to introduce different aryl or heteroaryl groups [60-64], as well as other functions [8,65]. Our objective in this part is to predict the outcome of this aromatic electrophilic substitution $\left(\mathrm{S}_{\mathrm{E}} \mathrm{Ar}\right)$ in the case of 1-arylated 7-azaindoles. Indeed, if 7-azaindole can be easily iodinated at its 3-position in DMF containing iodine after treatment by potassium hydroxide [43], the behavior of 1-aryl-7-azaindoles has only been the subject of very few studies.

Liu, $\mathrm{Xu}$ and coworkers showed in 2014, during the rhodium-catalyzed chlorination of 7-azaindoles, that 3-iodo-1-phenyl-7-azaindole could be obtained by reacting 1a with $\mathrm{N}$-iodosuccinimide (NIS; 1 equiv) and potassium hydroxide (3 equiv) in acetonitrile at $\mathrm{rt}$ for $11 \mathrm{~h} \mathrm{[66].} \mathrm{Inspired} \mathrm{by} \mathrm{their} \mathrm{protocol,} \mathrm{we} \mathrm{replaced} \mathrm{NIS} \mathrm{with} \mathrm{iodine} \mathrm{and} \mathrm{isolated} \mathrm{1a} \mathrm{with} \mathrm{a}$ yield of $65 \%$ (Table 3 , entry 1 ). The present reaction takes place at the carbon site possessing the most negative atomic charge ( $C$ charge; Figure 9$)$. Another way to rationalize the regioselectivity of $S_{E} A r$ reactions $[67,68]$ is to use Fukui's concept (an aromatic compound reacts with an electrophile at its carbon having the highest orbital coefficient of HOMO in absolute value) [69] and thus to calculate the HOMO coefficients by applying Hückel's theory [70-72] (Figure 9). In the present case, both approaches converge toward a $\mathrm{S}_{\mathrm{E}} \mathrm{Ar}$ at C3.

Table 3. Direct iodination of the 1-arylated 7-azaindoles.

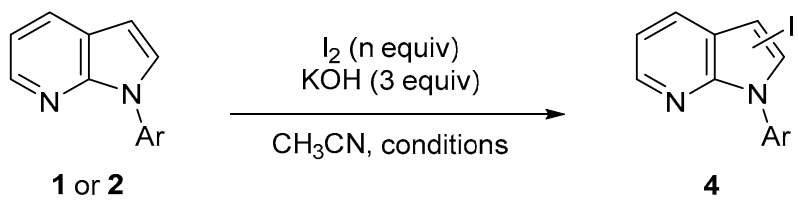

Entry


Table 3. Cont.

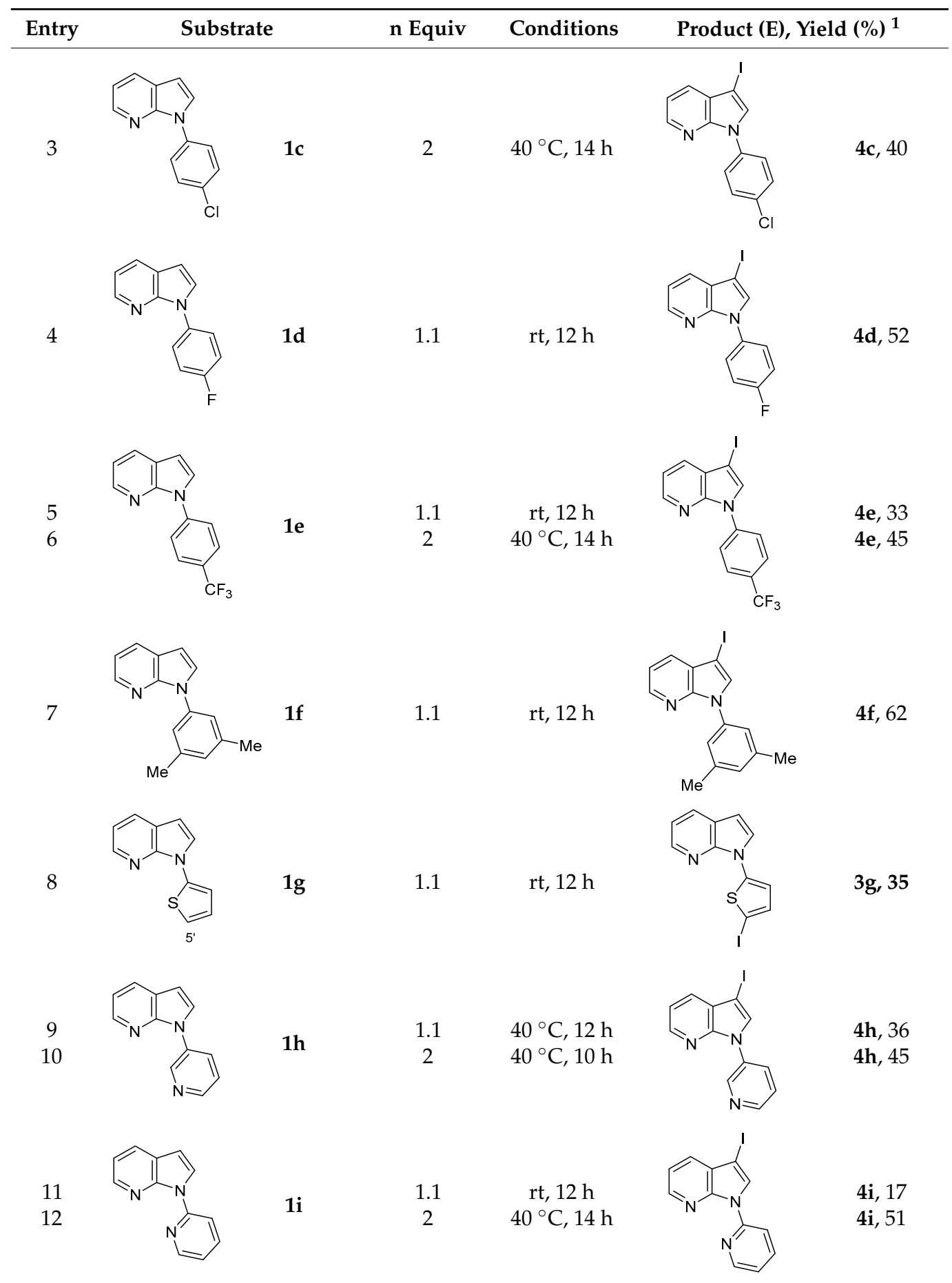

${ }_{1}^{1}$ After purification (see experimental part); when low yields were recorded, starting materials were in general recovered.

Next, we determined the charges and HOMO coefficients for the 1-arylated 7-azaindoles to attempt a prediction of the experimental results. For the 7-azaindoles bearing a substituted phenyl group $\mathbf{1 b}-\mathbf{1 f}$, all the maximum HOMO coefficients and the most negative $\mathrm{C}$ charges were found at C3 (Figure 10). Experimentally, the 3-iodinated derivatives $4 \mathbf{b}, 4 \mathbf{c}$, $4 \mathbf{d}$ and $\mathbf{4 f}$ were indeed the only products formed, as expected; they were isolated in yields ranging from $40 \%$ to $62 \%$ (Table 3 , entries 2, 3, 4 and 7 ). It is interesting to note that the yield of the 3-iodinated product can be slightly improved by carrying out the reaction at $40{ }^{\circ} \mathrm{C}$ with an excess of iodine, as for example noticed in $1 \mathbf{e}$ (Table 3, entries 5 and 6). 

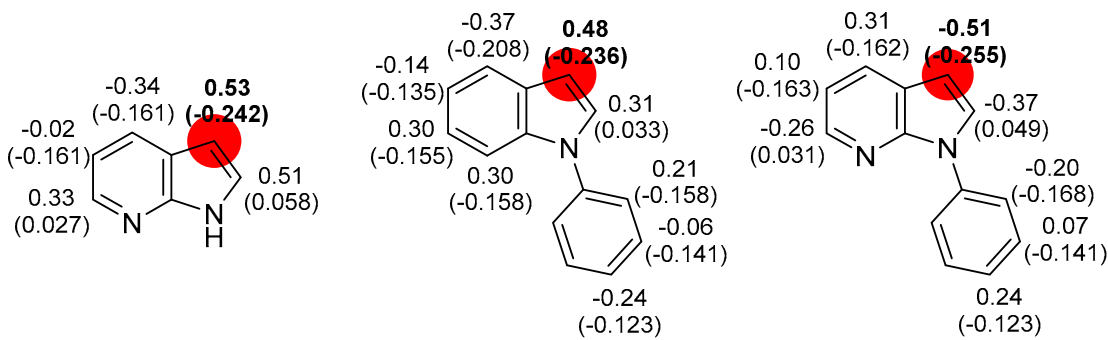

Figure 9. Calculated $\mathrm{C}$ charges (in brackets) and HOMO coefficients obtained by using the HuLiS calculator [73] for 7-azaindole, 1-phenylindole and 1-phenyl-7-azaindole (1a).

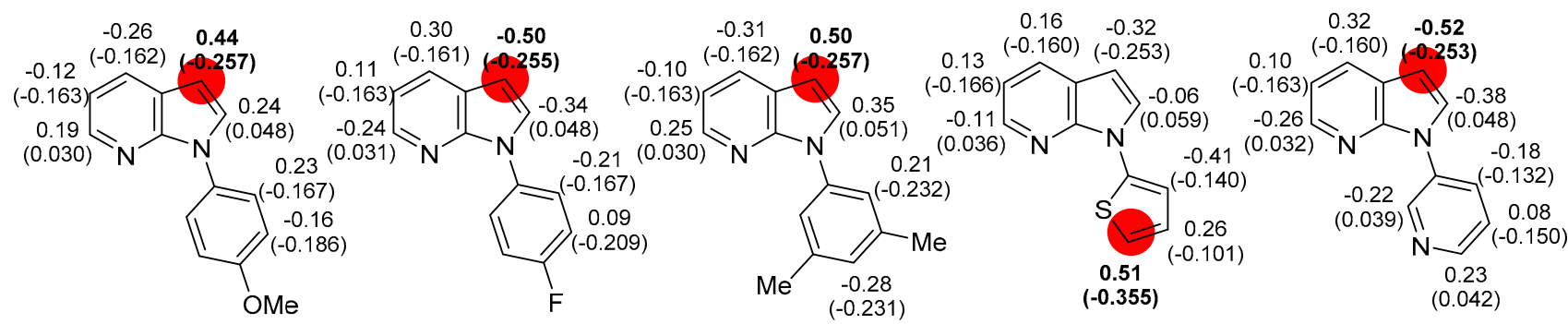

Figure 10. Calculated $\mathrm{C}$ charges (in brackets) and HOMO coefficients (obtained by using the HuLiS calculator [73]) for 1-(4-methoxyphenyl)-7-azaindole (1b), 1-(4-fluorophenyl)-7-azaindole (1d), 1-(3,5-dimethylphenyl)-7-azaindole (1f), 1-(2-thienyl)-7-azaindole (1g) and 1-(3-pyridyl)-7-azaindole (1h).

Since thiophene is also a five-membered heteroaromatic prone to $S_{E} A r$, it was interesting to consider the iodination of 1-(2-thienyl)-7-azaindole (19). Indeed, the calculations carried out as before showed a maximum HOMO coefficient and a most negative $\mathrm{C}$ charge at the 5-position of the thienyl ring (Figure 10). Experimentally, we obtained the 5-iodinated derivative $\mathbf{3 g}$ (Table 3 , entry 8 ), which is the compound already formed by deprotometalation-iodolysis (Table 2, entry 4). With regard to 1-pyridyl-7-azaindoles $\mathbf{1 h}-\mathbf{1} \mathbf{j}$, direct iodination at $\mathrm{C} 3$ is expected (Figure 10). As assumed, by carrying out the reaction from the 3- and 2-pyridyl substrates, we observed the formation of the 3-iodinated derivatives $4 \mathbf{h}$ and $4 \mathbf{i}$ as the only reaction products (Table 3, entries 9-12). Therefore, it appears that $\mathrm{HOMO}$ coefficients and carbon atomic charges can be used to predict the regioselectivity of $\mathrm{S}_{\mathrm{E}}$ Ar iodination reactions.

Throughout this study, the regioselectivity was established by NMR and confirmed for the products $\mathbf{4 c}, \mathbf{4 e}, \mathbf{4 h}$ and $\mathbf{4 i}$ by X-ray diffraction (Figure 11). For $\mathbf{4 c}$, short intermolecular contacts were observed at the solid state between the nitrogen of the azaindole pyridine and the hydrogen at $\mathrm{C} 2{ }^{\prime}(2.734 \AA)$, at the origin of a linear chain, while these chains are linked by short chlorine-iodine contacts (3.569 A) (Figure 12A). The molecular networks of $4 \mathbf{e}, 4 \mathrm{~h}$ and $4 \mathbf{i}$ all exhibit intermolecular halogen bonds [58] in which the iodine atoms are connected to the pyridine nitrogens. For 4e (Figure 12B) and $4 \mathrm{~h}$ (Figure 12C), these weak interactions bind the heavy halogen and the nitrogen of the azaindole pyridine and thus create linear chains (with iodine-nitrogen distances alternating between 3.137 and $3.158 \AA$ for the first and $3.497 \AA$ for the second). In the case of $4 \mathbf{i}$, the iodine is instead linked to the 2-pyridyl attached to the azaindole core, this time establishing a zig-zag chain (iodine-nitrogen distance of $3.283 \AA$ ) (Figure 12D). 

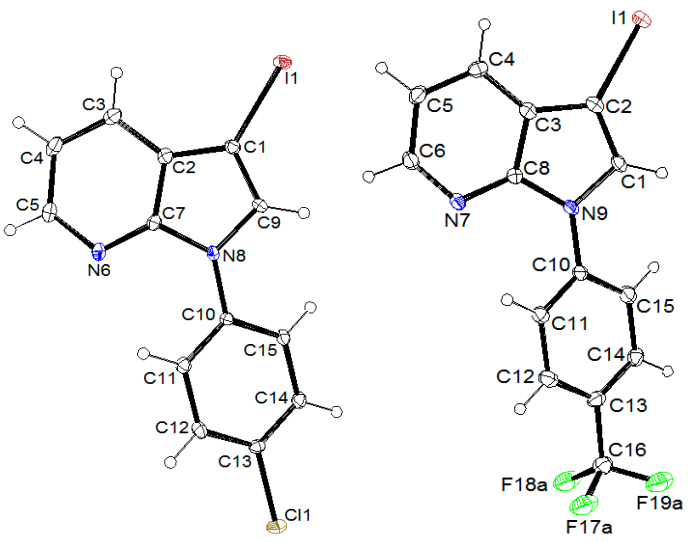

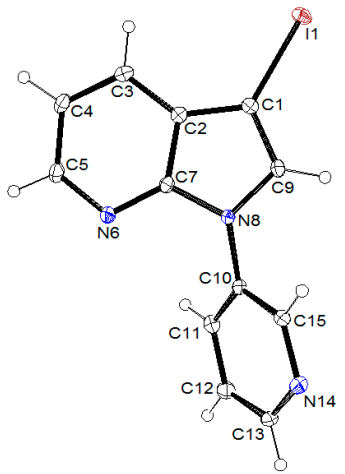

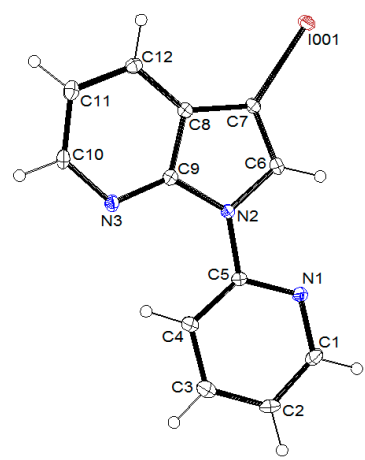

Figure 11. ORTEP diagrams (30\% probability) of $4 \mathbf{c}, 4 \mathbf{e}, 4 \mathbf{h}$ and $4 \mathbf{i}$.
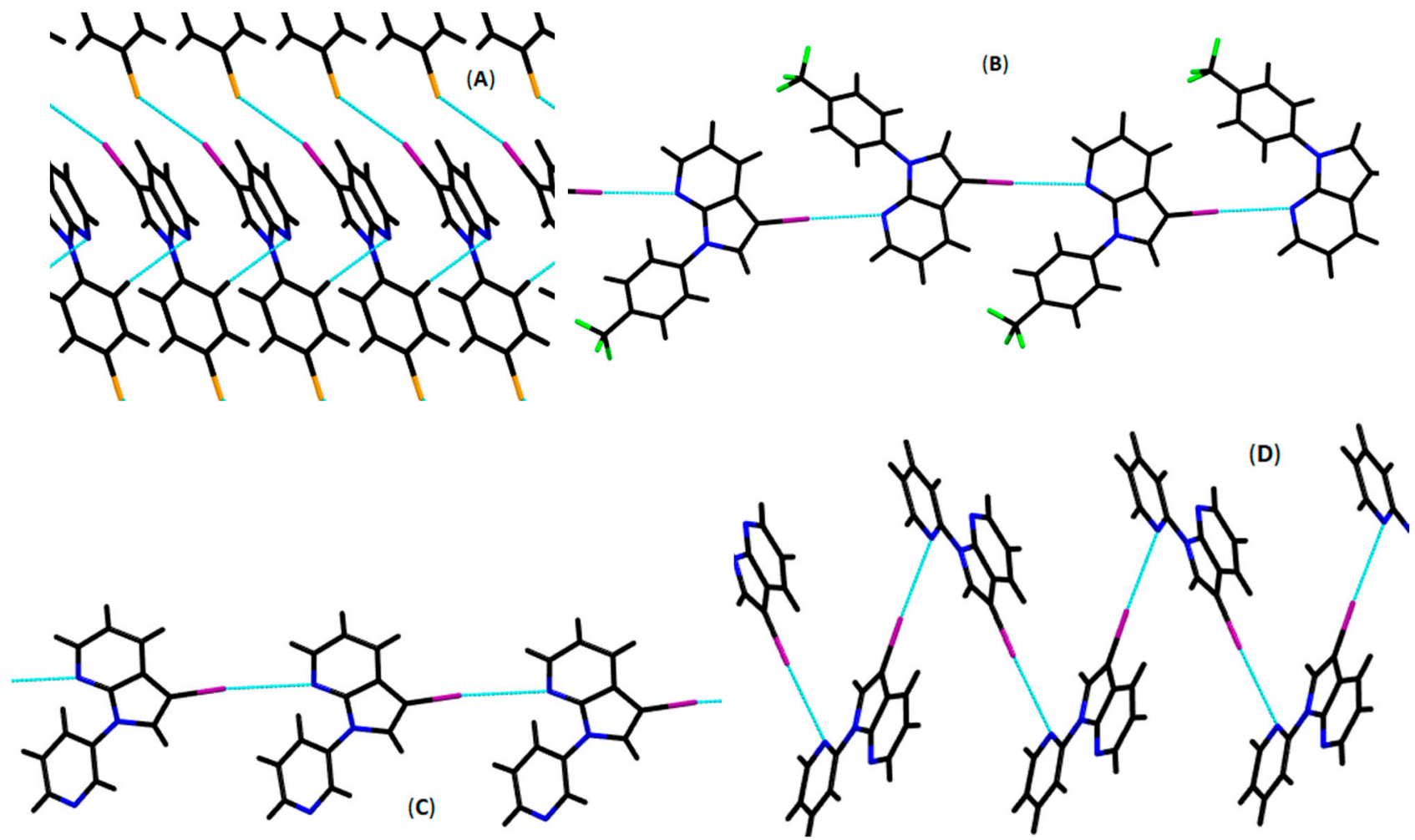

Figure 12. Short-contact network observed for 4c (A); halogen bond networks observed for $4 \mathbf{e}(\mathrm{B}), \mathbf{4 h}(\mathrm{C})$ and $4 \mathbf{i}(\mathrm{D})$.

\subsection{N-Arylation of Indole by a Few of the Prepared Iodides}

Because the $N$-arylation of indole with such iodinated 7-azaindoles can lead to original molecules with properties for potential applications [74-76], we selected the iodides $4 \mathbf{e}$ and $\mathbf{4} \mathbf{i}$ as well as the diiodide $\mathbf{3} \mathbf{g}^{\prime}$ for this purpose (Table 4). As already generally observed in Table 1, Method C has proved to be superior to Method D; in fact, while the trifluoromethylated product $5 \mathbf{e}$ was only isolated with a yield of $30 \%$ (entry 1 ), that containing pyridine $5 \mathbf{i}$ was obtained with a yield greater than $50 \%$ (entry 2 ).

Copper-catalyzed double $N$-arylation reactions are often difficult to perform due to competitive deiodination under the conditions required for second coupling [77]. However, despite a complex reaction mixture, the expected biscoupled product $\mathbf{6 g}^{\prime}$ was here isolated with a moderate yield of $20 \%$ (entry 3 ). 
Table 4. $\mathrm{N}$-arylation of indole by a few of the prepared iodides.

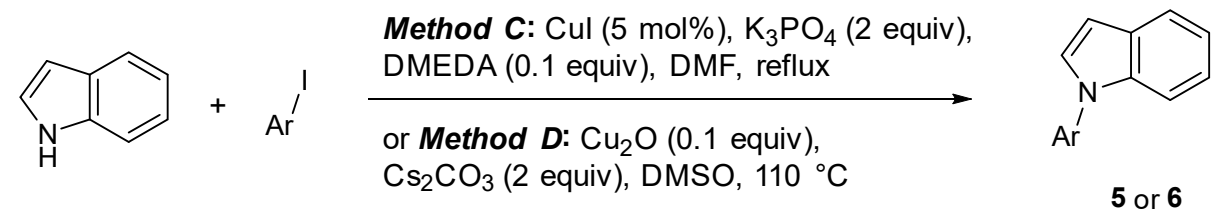

Entry Ar-I (n Equiv) Method (Time)

${ }^{1}$ After purification (see experimental part). ${ }^{2}$ The rest was mainly recovered starting material. ${ }^{3}$ A low yield was obtained, due to difficult separation.

In the case of $\mathbf{5 i}$, crystals suitable for X-ray diffraction (Figure 13A) made it possible to detect several short intermolecular contacts at the solid state. First, 2-pyridyl nitrogens are close to azaindole H6 (2.638 $⿱$ ) , the origin of linear chains. The 2-pyridyl ring is almost coplanar with the azaindole backbone $\left(6.37^{\circ}\right)$, with its nitrogen positioned outward, while the indole ring makes a $50.6^{\circ}$ twist angle, presumably to reduce the steric hindrance between the two bicyclic cores. These linear chains are in parallel plans successively separated by $3.368 \AA$ (azaindole C4-pyridine C2"; see Table 4, entry 2 for numbering) and $3.399 \AA$ (azaindole C5-pyridine C2"). Finally, short distances can be found between pyridine $\mathrm{H} 6$ " and both indole $\mathrm{C}^{\prime}(2.795 \AA)$ and $\mathrm{Ca}^{\prime}(2.878 \AA)$, and between pyridine $\mathrm{H} 3$ " and indole C2' (2.866 A) (Figure 13B).
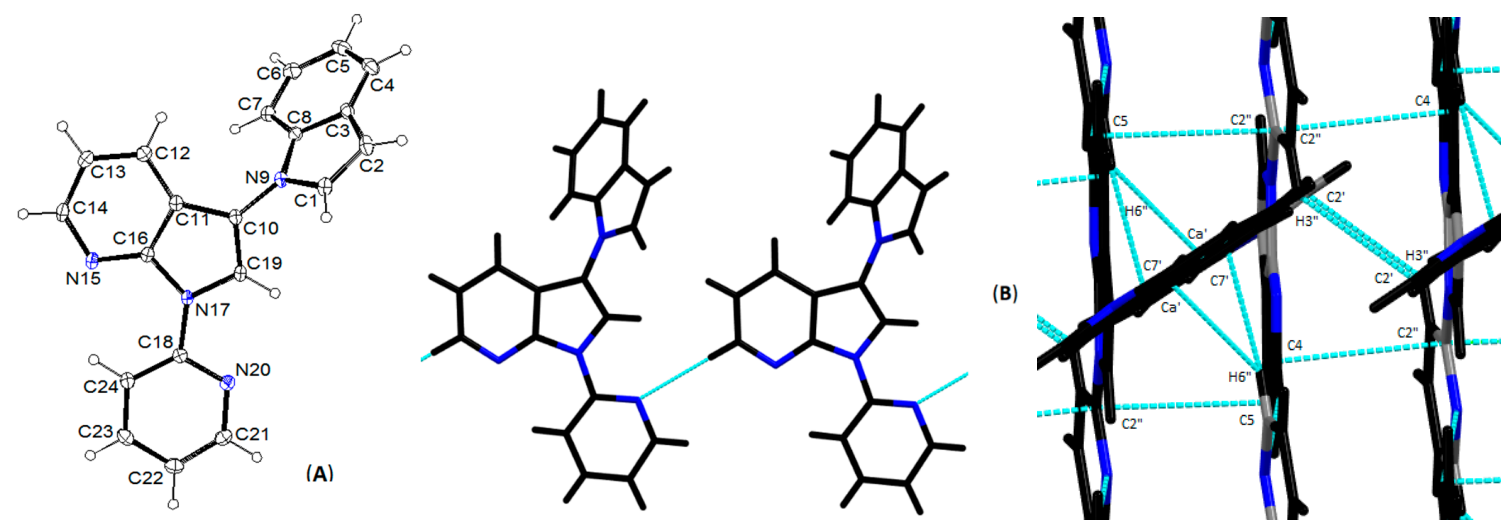

Figure 13. ORTEP diagrams (30\% probability) of 5i (A); short-contact networks observed for $5 \mathbf{i}(\mathbf{B})$. 


\subsection{Biological Evaluation}

As 7-azaindole is present in bioactive molecules, some of the compounds synthesized have been screened for their biological properties [77-79]. The compounds $\mathbf{1 a - c , 1 e , 1 f}$, $\mathbf{1 h}-\mathbf{j}, \mathbf{2 k}, \mathbf{2 l}, \mathbf{3 a}, \mathbf{3 g}, \mathbf{3} \mathrm{g}^{\prime}$ and $\mathbf{5 i}$ were evaluated for their antimicrobial activity against bacteria and for their antifungal activity (Table 5). No clear effect on microbial growth of strains of E. coli, P. aeruginosa and S. aureus was detected. For $\mathbf{1} \mathbf{i}$ and $\mathbf{1} \mathbf{j}$, an effect on the growth of E. faecium was noticed. However, the most significant growth inhibitions were found for L. monocytogenes (compound $\mathbf{1} \mathbf{j}$ ) and C. dubliniensis (compounds $\mathbf{1 a}, \mathbf{1} \mathbf{b}, \mathbf{1} \mathbf{h}$ and $\mathbf{1} \mathbf{i}$ ).

Table 5. Antimicrobial and antifungal activity ${ }^{1}$ of some of the synthesized compounds.

\begin{tabular}{|c|c|c|c|c|c|c|c|c|}
\hline 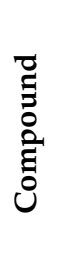 & 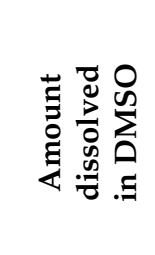 & 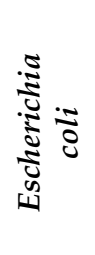 & 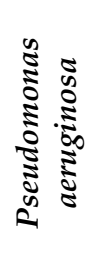 & 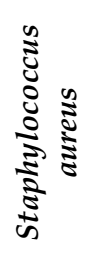 & 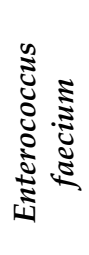 & 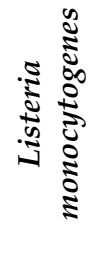 & 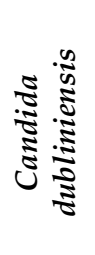 & 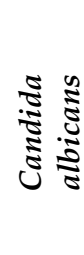 \\
\hline $1 a$ & $500 \mu g^{2}$ & 6 & 5 & 8 & 5 & \pm & 23 & - \\
\hline $1 b$ & $250 \mu g^{3}$ & 0 & 0 & 0 & 11 & 0 & 18 & - \\
\hline 1c & $150 \mu g^{4}$ & 0 & 0 & 0 & 0 & 0 & - & 0 \\
\hline 1e & $500 \mu g^{2}$ & \pm & 0 & 0 & 0 & 0 & 0 & - \\
\hline 1f & $200 \mu g^{3}$ & 0 & 0 & 0 & 11 & 0 & 13 & - \\
\hline 1h & $500 \mu g^{2}$ & 10 & 8 & 11 & 0 & 10 & 27 & - \\
\hline $1 \mathbf{i}$ & $250 \mu g^{3}$ & 0 & 0 & \pm & 13 & 0 & 16 & - \\
\hline $1 \mathrm{j}$ & $250 \mu \mathrm{g}^{3}$ & 0 & 0 & 0 & 15 & 22 & 10 & - \\
\hline $2 k$ & $150 \mu g^{4}$ & 0 & 0 & 0 & 0 & 0 & - & 0 \\
\hline 21 & $500 \mu g^{2}$ & 0 & 0 & 0 & 0 & 0 & 0 & - \\
\hline $3 a$ & $500 \mu g^{2}$ & 0 & 0 & 0 & 0 & 0 & 13 & - \\
\hline $3 g$ & $500 \mu g^{2}$ & \pm & 0 & 0 & 0 & 0 & 0 & - \\
\hline $3 \mathrm{~g}^{\prime}$ & $500 \mu g^{2}$ & \pm & \pm & 0 & 0 & 0 & 0 & - \\
\hline $5 i$ & $500 \mu g^{2}$ & 0 & 0 & 0 & 0 & 0 & 0 & - \\
\hline \multicolumn{2}{|c|}{$\begin{array}{l}\text { Reference } \\
\text { compound }\end{array}$} & $28^{5}$ & $28^{5}$ & $18^{6}$ & $24^{6}$ & $30^{7}$ & $10^{8}$ & - \\
\hline
\end{tabular}

${ }^{1}$ The diameters of zones of inhibition are given in mm. ${ }^{2} 10 \mu \mathrm{L} /$ well. ${ }^{3} 50 \mu \mathrm{L} /$ well. ${ }^{4} 30 \mu \mathrm{L} /$ well. ${ }^{5}$ Ceftazidim $(30 \mu \mathrm{g}) .{ }^{6}$ Vancomycin $(30 \mu \mathrm{g}) .{ }^{7}$ Amoxicillin $(25 \mu \mathrm{g}) .{ }^{8}$ Nystatin $(416 \mathrm{UI})$.

The antioxidant properties of a few selected compounds were finally evaluated. As shown in Table 6 , the compounds $\mathbf{1 b}, \mathbf{1 c}, \mathbf{1 f}, \mathbf{1 i}, \mathbf{1} \mathbf{j}$ and $\mathbf{5 i}$ have about $50 \%$ activity. The hemolytic activity of $\mathbf{1 b}, \mathbf{1} \mathbf{f}, \mathbf{1} \mathbf{i}$ and $\mathbf{1} \mathbf{j}$, which were found active against Candida dubliniensis or Listeria monocytogenes, was also evaluated and found to be less than $15 \%$ at a concentration of $5 \mu \mathrm{g} / \mu \mathrm{L}$. This low toxicity on human red blood cells, for compounds exhibiting an antimicrobial effect, demonstrates a specific antibacterial or antifungal effect and thus highlights a possible therapeutic interest. Concerning $\mathbf{1 a}, \mathbf{1} \mathbf{h}$ and $\mathbf{3 a}$, all active against Candida dubliniensis, the hemolytic activity tested at a concentration of $10 \mu \mathrm{g} / \mu \mathrm{L}$ was found to be approximately $22 \%, 65 \%$ and $32 \%$, respectively (data not shown).

Table 6. Antioxidant activity of some of the synthesized compounds.

\begin{tabular}{ccc}
\hline Compound & RSA (\%) ${ }^{\mathbf{1}}$ at $\mathbf{t}=\mathbf{0}$ $\mathbf{m i n}$ & RSA (\%) ${ }^{\mathbf{1}}$ at $\mathbf{t}=\mathbf{3 0} \mathbf{~}$ in \\
\hline $\mathbf{1 b}$ & 52 & 54 \\
$\mathbf{1 c}$ & 98 & 58 \\
$\mathbf{1 f}$ & 42 & 48 \\
$\mathbf{1 i}$ & 44 & 46 \\
$\mathbf{1 j}$ & 55 & 58 \\
$\mathbf{5 i}$ & 51 & 53 \\
\hline
\end{tabular}

${ }^{1}$ Percentage of the radical scavenger activity (RSA) at a concentration of $5 \mu \mathrm{g} / \mu \mathrm{L}$ in DMSO at rt. 


\section{Materials and Methods}

\subsection{General Information}

Column chromatography separations were achieved on silica gel (40-63 $\mu \mathrm{m})$. Melting points were measured on a Kofler apparatus. InfraRed (IR) spectra were taken on an ATR Spectrum 100 spectrometer (Perkin-Elmer, Waltham, MA, USA) and the main absorption wavenumbers are given in $\mathrm{cm}^{-1} .{ }^{1} \mathrm{H}$ and ${ }^{13} \mathrm{C}$ nuclear magnetic resonance (NMR) spectra were recorded on an Avance III spectrometer (291 K) at 300 and $75 \mathrm{MHz}$, respectively (Bruker, Billevica, MA, USA). ${ }^{1} \mathrm{H}$ chemical shifts $(\delta)$ are given in ppm relative to the solvent residual peak, and ${ }^{13} \mathrm{C}$ chemical shifts are relative to the central peak of the solvent signal [80]. $\mathrm{ZnCl}_{2} \cdot$ TMEDA was prepared as reported previously [81].

\subsection{Crystallography}

The samples were studied with monochromatized Mo-K $\alpha$ radiation $(\lambda=0.71073 \AA)$. The X-ray diffraction data were collected at the temperature given in the product description by using either APEXII Bruker AXS diffractometer (graphite monochromator; compounds $1 \mathrm{e}, \mathbf{2 l}, \mathbf{3 g}, \mathbf{3 \mathrm { g } ^ { \prime }}, \mathbf{3 \mathrm { k } ^ { \prime }}, \mathbf{4 e}, \mathbf{4 h}, \mathbf{4 i}$ and $\mathbf{5 i}$ ), or D8 VENTURE Bruker AXS diffractometer equipped with a (CMOS) PHOTON 100 detector (multilayer monochromator; compounds 1e, $\mathbf{1 i}, \mathbf{1 j}, \mathbf{2 k}, \mathbf{3 a}, \mathbf{3} \mathbf{a}^{\prime}$ and $\mathbf{4 c}$ ). For the compounds $\mathbf{1 e}, \mathbf{1} \mathbf{i}, \mathbf{1 j}, \mathbf{2 1}, \mathbf{3 a}, \mathbf{3 g ^ { \prime }}, \mathbf{1 e}$ and $4 \mathbf{c}$, the structure was solved by direct methods using the SIR97 program [82] and then refined with full-matrix least-square methods based on F2 (SHELXL-97) [83] with the aid of the WINGX [84] program. All nonhydrogen atoms were refined with anisotropic atomic displacement parameters. $\mathrm{H}$ atoms were finally included in their calculated positions. For the compounds $2 \mathrm{k}, 3 \mathrm{a}^{\prime}, 3 \mathrm{~g}, 3 \mathrm{k}^{\prime}, \mathbf{4 e}, 4 \mathrm{~h}, 4 \mathrm{i}$ and $5 \mathrm{i}$, the structure was solved by dual-space algorithm using the SHELXT program [85] and then refined with full-matrix least-square methods based on F2 (SHELXL-2014) [86]. All nonhydrogen atoms were refined with anisotropic atomic displacement parameters. $\mathrm{H}$ atoms were finally included in their calculated positions. The molecular diagrams were generated by ORTEP-3 (version 2.02, University of Glasgow, Glasgow, UK) [87].

\subsection{Computational Details}

The DFT calculations were performed by using GAUSSIAN 09 package [88]. The B3LYP hybrid functional was employed. All optimized geometries were obtained by using the 6-31G(d) basis set without any symmetry constraints. The vibrational frequencies were calculated at the same level of theory in order to characterize stationary points and calculate zero-point vibrational energies (ZPVE) and thermal corrections. The total energy of species was found by using the 6-311 $+G(d, p)$ basis set. Further, the gas-phase Gibbs energies $\left(G^{0}{ }_{298}\right)$ were calculated by using Equation (1), as follows:

$$
G^{0}{ }_{298}=E+\mathrm{ZPVE}+H^{0}{ }_{0 \rightarrow 298}-\mathrm{TS}^{0}{ }_{298}
$$

The gas-phase acidity $\Delta G_{\text {acid }}$ was defined as the Gibbs energy of deprotonation of the corresponding substrate $\mathrm{R}-\mathrm{H}\left(\mathrm{R}-\mathrm{H}(\mathrm{g}) \rightarrow \mathrm{R}^{-}(\mathrm{g})+\mathrm{H}^{+}(\mathrm{g})\right)$ :

$$
\Delta G_{\text {acid }}=G^{0}{ }_{298}\left(\mathrm{R}^{-}\right)+G^{0}{ }_{298}\left(\mathrm{H}^{+}\right)-G^{0}{ }_{298}(\mathrm{R}-\mathrm{H})
$$

The solvent effect was simulated within the polarized continuum model (PCM) with the default parameters for THF [89]. The PCM energies were calculated at the B3LYP / 6-311 + G(d,p) level by using geometries optimized for isolated structures.

The following homodesmic reaction was composed for the $\mathrm{p} K_{\mathrm{a}}$ values calculation:

$$
\mathrm{R}-\mathrm{H}(\mathrm{s})+\operatorname{Het}^{-}(\mathrm{s}) \rightarrow \mathrm{R}^{-}(\mathrm{s})+\operatorname{Het}-\mathrm{H}(\mathrm{s})
$$

where Het- $\mathrm{H}$ is $\mathrm{N}$-methylindole. The latter was chosen as reference compound due to its structural similarity and since its $\mathrm{p} K_{\mathrm{a}}(\mathrm{THF})=38.1$ reported by Fraser et al. [54] was 
expected to be close to the substrates under consideration. Consequently, the Gibbs energy of the homodesmic reaction $\left(\Delta G_{\mathrm{r}, \mathrm{s}}\right)$ and the $\mathrm{p} K_{\mathrm{a}}$ value are related by the following equation:

$$
\mathrm{p} K_{\mathrm{a}}=38.1+\frac{1}{2.303} \cdot \frac{\Delta G_{r, s}}{R T}
$$

The atomic charges were calculated by using Mulliken population analysis. MO coefficients were generated by using the HuLiS calculator [73].

\subsection{1-Arylation of 7-Azaindole}

\subsubsection{General Procedure 1 Using Copper}

This was adapted from a reported protocol [27]. A mixture of 7-azaindole (0.18 g, $1.5 \mathrm{mmol})$, aryl iodide $(1.0 \mathrm{mmol})$ or diiodide $(0.50 \mathrm{mmol}), \mathrm{Cu}(13 \mathrm{mg}, 0.20 \mathrm{mmol}), \mathrm{Cs}_{2} \mathrm{CO}_{3}$ $(0.65 \mathrm{~g}, 2.0 \mathrm{mmol})$ in acetonitrile $(1 \mathrm{~mL})$ was heated at reflux under $\mathrm{Ar}$ (the reaction time is given in the product description). The reaction mixture was cooled to rt before addition of EtOAc $(20 \mathrm{~mL})$ and filtration. The solvent was removed under reduced pressure, and the crude was purified by chromatography over silica gel (the eluent is given in the product description).

\subsubsection{General Procedure 2 Using Copper(I) Iodide without Ligand}

This was adapted from a reported protocol [28]. A mixture of 7-azaindole (0.12 g, $1.0 \mathrm{mmol})$, aryl iodide $(1.1 \mathrm{mmol}), \mathrm{CuI}(19 \mathrm{mg}, 0.10 \mathrm{mmol}), \mathrm{K}_{2} \mathrm{CO}_{3}(0.41 \mathrm{~g}, 3.0 \mathrm{mmol})$ and $\mathrm{LiCl}(42 \mathrm{mg}, 1.0 \mathrm{mmol})$ in DMF $(1 \mathrm{~mL})$ was heated at $120^{\circ} \mathrm{C}$ for $24 \mathrm{~h}$ under Ar. The reaction mixture was cooled to rt before addition of an aqueous saturated solution of $\mathrm{NH}_{4} \mathrm{Cl}(20 \mathrm{~mL})$. Extraction with EtOAc $(3 \times 20 \mathrm{~mL})$, drying over $\mathrm{MgSO}_{4}$, removal of the solvent under reduced pressure, and purification of the crude over silica gel (the eluent is given in the product description) gave the product.

\subsubsection{General Procedure 3 Using Copper(I) Iodide with Ligand}

This was adapted from reported protocols [29]. A mixture of 7-azaindole $(0.12 \mathrm{~g}$, $1.0 \mathrm{mmol})$, aryl iodide $(1.2 \mathrm{mmol})$ or diiodide $(0.60 \mathrm{mmol}), \mathrm{CuI}(9.5 \mathrm{mg}, 50 \mu \mathrm{mol}), \mathrm{K}_{3} \mathrm{PO}_{4}$ $(0.42 \mathrm{~g}, 2.0 \mathrm{mmol})$ and DMEDA $(11 \mu \mathrm{L}, 0.10 \mathrm{mmol})$ in DMF $(1 \mathrm{~mL})$ was degassed and heated at reflux under $\mathrm{Ar}$ (the reaction time is given in the product description). The reaction mixture was cooled to rt. The residue was taken with EtOAc $(20 \mathrm{~mL})$ and filtrated over celite. Removal of the solvent under reduced pressure and purification of the crude over silica gel (the eluent is given in the product description) gave the product.

\subsubsection{General Procedure 4 Using Copper(I) Oxide}

This was adapted from a reported protocol [30]. A mixture of 7-azaindole $(0.24 \mathrm{~g}$, $2.0 \mathrm{mmol})$, aryl iodide $(1.0 \mathrm{mmol})$ or diiodide $(0.50 \mathrm{mmol}), \mathrm{Cu}_{2} \mathrm{O}(14 \mathrm{mg}, 0.10 \mathrm{mmol})$ and $\mathrm{Cs}_{2} \mathrm{CO}_{3}(0.65 \mathrm{~g}, 2.0 \mathrm{mmol})$ in DMSO $(1 \mathrm{~mL})$ was heated at $110{ }^{\circ} \mathrm{C}$ under $\mathrm{Ar}$ (the reaction time is given in the product description). The reaction mixture was cooled to rt. The residue was taken with EtOAc $(20 \mathrm{~mL})$ and filtrated over celite. Removal of the solvent under reduced pressure and purification of the crude over silica gel (the eluent is given in the product description) gave the product.

\subsubsection{General Procedure 5 Using Copper(I) Iodide and Microwaves}

This was adapted from a reported protocol [31]. A mixture of 7-azaindole $(0.12 \mathrm{~g}$, $1.0 \mathrm{mmol})$, aryl iodide $(1.1 \mathrm{mmol}), \mathrm{CuI}(19 \mathrm{mg}, 0.10 \mathrm{mmol})$ and $\mathrm{Cs}_{2} \mathrm{CO}_{3}(0.33 \mathrm{~g}, 1.0 \mathrm{mmol})$ in DMF (1 mL) was heated in a Whirpool M571 domestic microwave oven at $350 \mathrm{~W}$ (the reaction time is given in the product description). The reaction mixture was cooled to rt before addition of an aqueous saturated solution of $\mathrm{NH}_{4} \mathrm{Cl}(20 \mathrm{~mL})$. Extraction with EtOAc $(3 \times 20 \mathrm{~mL})$, drying over $\mathrm{MgSO}_{4}$, removal of the solvent under reduced pressure, and purification of the crude over silica gel (the eluent is given in the product description) gave the product. 


\subsubsection{1-Phenyl-1H-pyrrolo[2,3-b]pyridine or 1-Phenyl-7-azaindole (1a)}

The general procedure 1 (reaction time: $29 \mathrm{~h}), 2(24 \mathrm{~h}), 3(30 \mathrm{~h}), 4(24 \mathrm{~h})$ and 5 (15 $\mathrm{min})$ using iodobenzene $(0.11,0.12,0.13,0.11$ and $0.12 \mathrm{~mL}$, respectively) afforded (eluent: hexaneEtOAc 90:10) the title product in $20 \%, 15 \%, 75 \%, 75 \%$ and $18 \%$ yield, respectively, as a yellow oil. IR: 689, 705, 719, 751, 769, 796, 893, 954, 1029, 1072, 1111, 1146, 1179, 1210, 1235, 1269, 1288, 1322, 1360, 1421, 1457, 1476, 1496, 1513, 1590, 1731, 1863, 2582, 3047. ${ }^{1} \mathrm{H}-\mathrm{NMR}$ $\left(\mathrm{CDCl}_{3}\right): 6.63(\mathrm{~d}, 1 \mathrm{H}, J=3,6 \mathrm{~Hz}, \mathrm{H} 3), 7.15(\mathrm{dd}, 1 \mathrm{H}, J=7.8$ and $4.7 \mathrm{~Hz}, \mathrm{H} 5), 7.35(\mathrm{tt}, 1 \mathrm{H}$, $J=7.4$ and $\left.1.2 \mathrm{~Hz}, \mathrm{H} 4^{\prime}\right), 7.50-7.57(\mathrm{~m}, 3 \mathrm{H}, \mathrm{H} 2$ and $\mathrm{Ph}), 7.77-7.81(\mathrm{~m}, 2 \mathrm{H}, \mathrm{Ph}), 7.98(\mathrm{dd}, 1 \mathrm{H}$, $J=7.8$ and $1.6 \mathrm{~Hz}, \mathrm{H} 4), 8.43(\mathrm{dd}, 1 \mathrm{H}, J=4.7$ and $1.6 \mathrm{~Hz}, \mathrm{H} 6) .{ }^{13} \mathrm{C}-\mathrm{NMR}\left(\mathrm{CDCl}_{3}\right): 101.8(\mathrm{CH}$, C3), $116.9(\mathrm{CH}, \mathrm{C} 5), 121.8(\mathrm{C}, \mathrm{Cb}), 124.2\left(2 \mathrm{CH}, \mathrm{C2}^{\prime}\right.$ and $\left.\mathrm{C}^{\prime}\right), 126.5\left(\mathrm{CH}, \mathrm{C} 2\right.$ or $\left.\mathrm{C}^{\prime}\right), 128.1$ $\left(\mathrm{CH}, \mathrm{C} 2\right.$ or $\left.\mathrm{C}^{\prime}\right), 129.3(\mathrm{CH}, \mathrm{C} 4), 129.6\left(2 \mathrm{CH}, \mathrm{C}^{\prime}\right.$ and $\left.\mathrm{C}^{\prime}\right), 138.7\left(\mathrm{C}, \mathrm{C1}^{\prime}\right), 143.8(\mathrm{CH}, \mathrm{C} 6)$, 147.7 (C, Ca). These data are as reported [90].

\subsubsection{1-(4-Methoxyphenyl)-7-azaindole (1b)}

The general procedure 1 (reaction time: $6 \mathrm{~d}), 2(24 \mathrm{~h}), 3(6 \mathrm{~d}), 4(24 \mathrm{~h})$ and $5(25 \mathrm{~min})$ using 4-iodoanisole $(0.23,0.26,0.28,0.23$ and $0.26 \mathrm{~g}$, respectively) afforded (eluent: petroleum ether-EtOAc 70:30) the title product in $0 \%, 50 \%, 54 \%, 60 \%$ and $35 \%$ yield, respectively, as a yellow solid. Mp 56-58 ${ }^{\circ} \mathrm{C}$, IR: 670, 717, 764, 772, 796, 828, 894, 957, 1031, 1069, 1108, 1146, 1180, 1212, 1244, 1271, 1298, 1324, 1357, 1422, 1441, 1463, 1478, 1515, 1569, 1393, 1731, 1875, 2046, 2835, 2956, 3048. ${ }^{1} \mathrm{H}-\mathrm{NMR}\left(\mathrm{CDCl}_{3}\right): 3.81$ (s, 3H, OMe), $6.58(\mathrm{~d}, 1 \mathrm{H}, J=3.6 \mathrm{~Hz}$, $\mathrm{H} 3), 7.03-7.06\left(\mathrm{~m}, 2 \mathrm{H}, \mathrm{H}^{\prime}{ }^{\prime}\right.$ and $\left.\mathrm{H}^{\prime}\right), 7.10(\mathrm{dd}, 1 \mathrm{H}, J=7.8$ et $4.7 \mathrm{~Hz}, \mathrm{H} 5), 7.42(\mathrm{~d}, 1 \mathrm{H}, J=3.6$ $\mathrm{Hz}, \mathrm{H} 2), 7.59-7.62\left(\mathrm{~m}, 2 \mathrm{H}, \mathrm{H} 2^{\prime}\right.$ and $\left.\mathrm{H}^{\prime}\right), 7.94(\mathrm{dd}, 1 \mathrm{H}, J=7.8$ et $1.6 \mathrm{~Hz}, \mathrm{H} 4), 8.40(\mathrm{dd}, 1 \mathrm{H}$, $J=4.7$ and $1.6 \mathrm{~Hz}, \mathrm{H} 6) .{ }^{13} \mathrm{C}-\mathrm{NMR}\left(\mathrm{CDCl}_{3}\right): 55.4\left(\mathrm{CH}_{3}, \mathrm{OMe}\right), 100.9(\mathrm{CH}, \mathrm{C} 3), 114.4(2 \mathrm{CH}$, $\mathrm{C}^{\prime}{ }^{\prime}$ and $\left.\mathrm{C}^{\prime}\right), 116.3(\mathrm{CH}, \mathrm{C} 5), 121.1(\mathrm{C}, \mathrm{Cb}), 125.4\left(2 \mathrm{CH}, \mathrm{C2}^{\prime}\right.$ and $\left.\mathrm{C}^{\prime}\right), 128.1(\mathrm{CH}, \mathrm{C} 2), 128.9$ $(\mathrm{CH}, \mathrm{C} 4), 131.4\left(\mathrm{C}, \mathrm{C1}^{\prime}\right), 143.4(\mathrm{CH}, \mathrm{C} 6), 147.4(\mathrm{C}, \mathrm{Ca}), 157.9\left(\mathrm{C}, \mathrm{C} 4^{\prime}\right)$. The NMR data are as reported [90].

\subsubsection{1-(4-Chlorophenyl)-7-azaindole (1c)}

The general procedure $4(24 \mathrm{~h})$ using 1-chloro-4-iodobenzene $(0.24 \mathrm{~g})$ afforded (eluent: heptane-EtOAc 80:20) the title product in $65 \%$ yield as a white solid. Mp $92{ }^{\circ} \mathrm{C}$, IR: 716, $769,793,821,894,954,1095,1148,1210,1237,1267,1279,1326,1360,1421,1497,1521,1592$, 1724, 1891, 3054, 3075, 3113. ${ }^{1} \mathrm{H}-\mathrm{NMR}\left(\mathrm{CDCl}_{3}\right): 6.63(\mathrm{~d}, 1 \mathrm{H}, J=3.7 \mathrm{~Hz}, \mathrm{H} 3), 7.14(\mathrm{dd}, 1 \mathrm{H}$, $J=7.8$ and $4.7 \mathrm{~Hz}, \mathrm{H} 5), 7.46(\mathrm{~d}, J=3.8 \mathrm{~Hz}, 1 \mathrm{H}, \mathrm{H} 2), 7.46-7.50(\mathrm{~m}, 2 \mathrm{H}, \mathrm{Ph}), 7.71-7.76(\mathrm{~m}, 2 \mathrm{H}$, $\mathrm{Ph}), 7.96(\mathrm{dd}, 1 \mathrm{H}, J=7.8$ and $1.6 \mathrm{~Hz}, \mathrm{H} 4), 8.38(\mathrm{dd}, 1 \mathrm{H}, J=4.7$ and $1.6 \mathrm{~Hz}, \mathrm{H6}) .{ }^{13} \mathrm{C}-\mathrm{NMR}$ $\left(75 \mathrm{MHz}, \mathrm{CDCl}_{3}\right) \delta 102.2(\mathrm{CH}, \mathrm{C} 3), 117.0(\mathrm{CH}, \mathrm{C} 5), 121.7(\mathrm{C}, \mathrm{Cb}), 125.0(2 \mathrm{CH}, \mathrm{Ph}), 127.4$ $(\mathrm{CH}, \mathrm{C} 2), 129.3(\mathrm{CH}, \mathrm{C} 4), 129.5(2 \mathrm{CH}, \mathrm{Ph}), 131.8\left(\mathrm{C}, \mathrm{Cl}^{\prime}\right.$ or $\left.\mathrm{C}^{\prime}\right), 137.1\left(\mathrm{C}, \mathrm{Cl}^{\prime}\right.$ or $\left.\mathrm{C}^{\prime}\right), 143.8$ $(\mathrm{CH}, \mathrm{C} 6), 147.5(\mathrm{C}, \mathrm{Ca})$. These data are as reported [91].

\subsubsection{1-(4-Fluorophenyl)-7-azaindole (1d)}

The general procedure $4(24 \mathrm{~h})$ using 1-fluoro-4-iodobenzene $(0.12 \mathrm{~mL})$ afforded (eluent: petroleum ether-EtOAc 90:10) the title product in $80 \%$ yield as a greenish oil. IR: $672,717,765,772,796,816,832,894,956,1014,1040,1069,1096,1111,1146,1158,1219,1269$, 1287, 1325, 1358, 1424, 1507, 1515, 1574, 1592, 1724, 1883, 3050. ${ }^{1} \mathrm{H}-\mathrm{NMR}\left(\mathrm{CDCl}_{3}\right): 6.62(\mathrm{~d}$, $1 \mathrm{H}, J=3.6 \mathrm{~Hz}, \mathrm{H} 3), 7.13(\mathrm{dd}, 1 \mathrm{H}, J=7.8$ and $4.7 \mathrm{~Hz}, \mathrm{H} 5), 7.17-7.25(\mathrm{~m}, 2 \mathrm{H}, \mathrm{Ph}), 7.44(\mathrm{~d}$, $1 \mathrm{H}, J=3.6 \mathrm{~Hz}, \mathrm{H} 2), 7.67-7.74(\mathrm{~m}, 2 \mathrm{H}, \mathrm{Ph}), 7.97(\mathrm{dd}, 1 \mathrm{H}, J=7.8$ and $1.6 \mathrm{~Hz}, \mathrm{H} 4), 8.38(\mathrm{dd}$, $1 \mathrm{H}, J=4.7$ and $1.6 \mathrm{~Hz}, \mathrm{H} 6) .{ }^{13} \mathrm{C}-\mathrm{NMR}\left(75 \mathrm{MHz}, \mathrm{CDCl}_{3}\right): 101.8(\mathrm{CH}, \mathrm{C} 3), 116.2(\mathrm{~d}, 2 \mathrm{CH}$, $J=22.8 \mathrm{~Hz}, \mathrm{C}^{\prime}$ and $\left.\mathrm{C}^{\prime}\right), 116.8(\mathrm{CH}, \mathrm{C} 5), 121.5(\mathrm{C}, \mathrm{Cb}), 125.8\left(\mathrm{~d}, 2 \mathrm{CH}, J=8.3 \mathrm{~Hz}, \mathrm{C}^{\prime}\right.$ and $\left.\mathrm{C}^{\prime}\right), 127.8(\mathrm{CH}, \mathrm{C} 2), 129.2(\mathrm{CH}, \mathrm{C} 4), 134.6\left(\mathrm{~d}, \mathrm{C}, J=3.0 \mathrm{~Hz}, \mathrm{Cl}^{\prime}\right), 143.7(\mathrm{CH}, \mathrm{C} 6), 147.6(\mathrm{C}$, Ca), $161.0\left(\mathrm{~d}, \mathrm{C}, J=246 \mathrm{~Hz}, \mathrm{C4}{ }^{\prime}, \mathrm{C}-\mathrm{F}\right)$. These data are as reported [66].

\subsubsection{1-(4-(Trifluoromethyl)phenyl)-7-azaindole (1e)}

The general procedure 3 (reaction time: $24 \mathrm{~h}$ ) and $4(24 \mathrm{~h})$ using 1-iodo-4-(trifluoro methyl)benzene ( 0.18 and $0.15 \mathrm{~mL}$, respectively) afforded (eluent: petroleum ether-EtOAc $90: 10$ ) the title product in $95 \%$ and $65 \%$ yield, respectively, as a yellow solid. Mp $66-68{ }^{\circ} \mathrm{C}$, 
IR: 706, 727, 764, 771, 796, 832, 895, 960, 1018, 1043, 1065, 1080, 1109, 1166, 1209, 1240, $1267,1322,1361,1425,1478,1529,1572,1595,1617,1889,3069 .{ }^{1} \mathrm{H}-\mathrm{NMR}\left(\mathrm{CDCl}_{3}\right): 6.68$ $(\mathrm{d}, 1 \mathrm{H}, J=3.7 \mathrm{~Hz}, \mathrm{H} 3), 7.18(\mathrm{dd}, 1 \mathrm{H}, J=7.8$ and $4.7 \mathrm{~Hz}, \mathrm{H} 5), 7.54(\mathrm{~d}, 1 \mathrm{H}, J=3.7 \mathrm{~Hz}$, $\mathrm{H} 2), 7.77(\mathrm{~d}, 2 \mathrm{H}, J=8.4 \mathrm{~Hz}, \mathrm{Ph}), 7.96-8.01(\mathrm{~m}, 3 \mathrm{H}, \mathrm{H} 4$ and $\mathrm{Ph}), 8.39(\mathrm{dd}, 1 \mathrm{H}, J=4.7$ and $1.5 \mathrm{~Hz}, \mathrm{H} 6) .{ }^{13} \mathrm{C}-\mathrm{NMR}\left(\mathrm{CDCl}_{3}\right): 103.0(\mathrm{CH}, \mathrm{C} 3), 117.4(\mathrm{CH}, \mathrm{C} 5), 122.0(\mathrm{C}, \mathrm{Cb}), 123.4(2 \mathrm{CH}$, $\mathrm{C}^{\prime}$ and $\left.\mathrm{C}^{\prime}\right), 124.2\left(\mathrm{q}, \mathrm{C}, J=272 \mathrm{~Hz}, \mathrm{CF}_{3}\right), 126.7\left(\mathrm{q}, 2 \mathrm{CH}, J=3.7 \mathrm{~Hz}, \mathrm{C}^{\prime}\right.$ and $\left.\mathrm{C}^{\prime}\right), 127.1$ (CH, C2), 127.9 (q, C, J = 33 Hz, C4'), 129.5 (CH, C4), 141.5 (C, C1'), 143.9 (CH, C6), 147.6 $(\mathrm{C}, \mathrm{Ca})$. The NMR data are close to those reported [92]. Crystal data for 1e. $\mathrm{C}_{14} \mathrm{H}_{9} \mathrm{~F}_{3} \mathrm{~N}_{2}$, $M=262.23, T=150(2) \mathrm{K}$, monoclinic, $P 22_{1} / c, a=13.0804(9), b=6.9738(5), c=13.7561(8) \AA$, $\beta=111.263(2)^{\circ}, V=1169.41(13) \AA^{3}, Z=4, d=1.489 \mathrm{~g} \mathrm{~cm}^{-3}, \mu=0.123 \mathrm{~mm}^{-1}$. A final refinement on $F^{2}$ with 2648 unique intensities and 203 parameters converged at $\omega R\left(F^{2}\right)=0.1172$ $(R(F)=0.0464)$ for 2105 observed reflections with $I>2 \sigma(I)$. CCDC 2109688. Other crystal data for 1e. $\mathrm{C}_{14} \mathrm{H}_{9} \mathrm{~F}_{3} \mathrm{~N}_{2}, M=262.23, T=150(2) \mathrm{K}$, monoclinic, $P 2{ }_{1} / c, a=13.154(5), b=7.248(3)$, $c=13.796(5) \AA, \beta=117.791(12)^{\circ}, V=1163.7(7) \AA^{3}, Z=4, d=1.497 \mathrm{~g} \mathrm{~cm}^{-3}, \mu=0.124 \mathrm{~mm}^{-1}$. A final refinement on $F^{2}$ with 2660 unique intensities and 182 parameters converged at $\omega R\left(F^{2}\right)=0.1833(R(F)=0.0916)$ for 1477 observed reflections with $I>2 \sigma(I)$. CCDC 2109687 .

\subsubsection{1-(3,5-Dimethylphenyl)-7-azaindole (1f)}

The general procedure 3 (reaction time: $24 \mathrm{~h}$ ) using 1-iodo-3,5-dimethylbenzene $(0.17 \mathrm{~mL})$ afforded (eluent: petroleum ether-EtOAc 90:10) the title product in $97 \%$ yield as a yellow oil. IR: 689, 717, 763, 772, 795, 814, 844, 893, 1037, 1083, 1138, 1205, 1261, 1281, 1330, 1359, 1414, 1479, 1512, 1591, 1611, 2917, 3014. ${ }^{1} \mathrm{H}-\mathrm{NMR}\left(\mathrm{CDCl}_{3}\right): 2.42$ (d, 6H, J = $0.5 \mathrm{~Hz}$, $\mathrm{Me}), 6.60(\mathrm{~d}, 1 \mathrm{H}, J=3.6 \mathrm{~Hz}, \mathrm{H} 3), 7.00\left(\mathrm{br} \mathrm{s}, 1 \mathrm{H}, \mathrm{H} 4^{\prime}\right), 7.12(\mathrm{dd}, 1 \mathrm{H}, J=7.8$ and $4.7 \mathrm{~Hz}, \mathrm{H} 5)$, $7.36\left(\mathrm{br} \mathrm{s}, 2 \mathrm{H}, \mathrm{H}^{\prime}{ }^{\prime}\right.$ and $\left.\mathrm{H6}^{\prime}\right), 7.48(\mathrm{~d}, 1 \mathrm{H}, J=3.6 \mathrm{~Hz}, \mathrm{H} 2), 7.96(\mathrm{dd}, 1 \mathrm{H}, J=7.8$ and $1.6 \mathrm{~Hz}$, $\mathrm{H} 4), 8.40(\mathrm{dd}, 1 \mathrm{H}, J=4.7$ and $1.6 \mathrm{~Hz}, \mathrm{H} 6) .{ }^{13} \mathrm{C}-\mathrm{NMR}\left(\mathrm{CDCl}_{3}\right): 21.5\left(2 \mathrm{CH}_{3}, \mathrm{Me}\right), 101.2(\mathrm{CH}$, C3), $116.5(\mathrm{CH}, \mathrm{C} 5), 121.5(\mathrm{C}, \mathrm{Cb}), 122.2\left(2 \mathrm{CH}, \mathrm{C}^{\prime}\right.$ and $\left.\mathrm{C6}^{\prime}\right), 128.3\left(2 \mathrm{CH}, \mathrm{C} 2\right.$ and $\left.\mathrm{C}^{\prime}\right), 129.0$ $(\mathrm{CH}, \mathrm{C} 4), 138.4\left(\mathrm{C}, \mathrm{C1}^{\prime}\right), 139.1\left(2 \mathrm{C}, \mathrm{C}^{\prime}\right.$ and $\left.\mathrm{C}^{\prime}\right), 143.6(\mathrm{CH}, \mathrm{C} 6), 147.7(\mathrm{C}, \mathrm{Ca})$. These data are close to those reported [93].

\subsubsection{1-(2-Thienyl)-7-azaindole (1g)}

The general procedure 2 (reaction time: $24 \mathrm{~h}$ ) and 3 (48 h) using 2-iodothiophene (0.12 and $0.13 \mathrm{~mL}$, respectively) afforded (eluent: heptane-EtOAc 90:10) the title product in 37\% and $92 \%$ yield, respectively, as a yellow oil. ${ }^{1} \mathrm{H}-\mathrm{NMR}\left(\mathrm{CDCl}_{3}\right): 6.60(\mathrm{~d}, 1 \mathrm{H}, J=3.7 \mathrm{~Hz}, \mathrm{H} 3)$, $7.03\left(\mathrm{dd}, 1 \mathrm{H}, J=5.5\right.$ and $\left.3.7 \mathrm{~Hz}, \mathrm{H} 4^{\prime}\right), 7.12-7.16\left(\mathrm{~m}, 2 \mathrm{H}, \mathrm{H} 5\right.$ and $\left.\mathrm{H} 5^{\prime}\right), 7.28(\mathrm{dd}, 1 \mathrm{H}, J=3.7$ and $\left.1.4 \mathrm{~Hz}, \mathrm{H3}^{\prime}\right), 7.49(\mathrm{~d}, 1 \mathrm{H}, J=3.7 \mathrm{~Hz}, \mathrm{H} 2), 7.93(\mathrm{dd}, 1 \mathrm{H}, J=7.8$ and $1.6 \mathrm{~Hz}, \mathrm{H} 4), 8.43(\mathrm{dd}$, $1 \mathrm{H}, J=4.7$ and $1.6 \mathrm{~Hz}, \mathrm{H} 6) .{ }^{13} \mathrm{C}-\mathrm{NMR}\left(\mathrm{CDCl}_{3}\right): 102.3(\mathrm{CH}, \mathrm{C} 3), 117.1\left(\mathrm{CH}, \mathrm{C} 5\right.$ or $\left.\mathrm{C}^{\prime}\right), 117.8$ $\left(\mathrm{CH}, \mathrm{C} 5\right.$ or $\left.\mathrm{C}^{\prime}\right), 120.6(\mathrm{CH}), 121.4(\mathrm{C}, \mathrm{Cb}), 125.7(\mathrm{CH}), 128.2(\mathrm{CH}), 129.2(\mathrm{CH}, \mathrm{C} 4), 139.8(\mathrm{C}$, $\left.\mathrm{C}^{\prime}\right), 143.9(\mathrm{CH}, \mathrm{C} 6), 147.4(\mathrm{C}, \mathrm{Ca})$. The NMR data are as reported [74].

\subsubsection{1-(3-Pyridyl)-7-azaindole (1h)}

The general procedure 3 (reaction time: $48 \mathrm{~h}$ ) and $4(24 \mathrm{~h})$ using 3-iodopyridine $(0.25$ and $0.205 \mathrm{~g}$, respectively) afforded (eluent: heptane-EtOAc 70:30) the title product in 80\% yield as a white solid. Mp 70-72 ${ }^{\circ} \mathrm{C}$, IR: 705, 721, 766, 774, 799, 894, 955, 1023, 1043, 1075, 1112, 1150, 1190, 1212, 1243, 1272, 1329, 1365, 1419, 1438, 1488, 1517, 1584, 1897, 2160, 3046, 3429. ${ }^{1} \mathrm{H}-\mathrm{NMR}\left(\mathrm{CDCl}_{3}\right): 6.65(\mathrm{~d}, 1 \mathrm{H}, J=3.7 \mathrm{~Hz}, \mathrm{H} 3), 7.14(\mathrm{dd}, 1 \mathrm{H}, J=7.9$ and $4.7 \mathrm{~Hz}, \mathrm{H} 5)$, $7.43\left(\mathrm{ddd}, 1 \mathrm{H}, J=8.3,4.8\right.$ and $\left.0.6 \mathrm{~Hz}, \mathrm{H}^{\prime}\right), 7.50(\mathrm{~d}, 1 \mathrm{H}, J=3.7 \mathrm{~Hz}, \mathrm{H} 2), 7.95(\mathrm{dd}, 1 \mathrm{H}, J=7.9$ and $1.6 \mathrm{~Hz}, \mathrm{H} 4), 8.26\left(\mathrm{ddd}, 1 \mathrm{H}, J=8.3,2.6\right.$ and $\left.1.5 \mathrm{~Hz}, \mathrm{H}^{\prime}\right), 8.35(\mathrm{dd}, 1 \mathrm{H}, J=4.7$ and $1.6 \mathrm{~Hz}$, H6), $8.55\left(\mathrm{dd}, 1 \mathrm{H}, J=4.7\right.$ and $\left.1.4 \mathrm{~Hz}, \mathrm{H}^{\prime}\right), 8.98\left(\mathrm{~d}, 1 \mathrm{H}, J=2.4 \mathrm{~Hz}, \mathrm{H} 2^{\prime}\right) .{ }^{13} \mathrm{C}-\mathrm{NMR}\left(\mathrm{CDCl}_{3}\right)$ : $102.8(\mathrm{CH}, \mathrm{C} 3), 117.3(\mathrm{CH}, \mathrm{C} 5), 121.7(\mathrm{C}, \mathrm{Cb}), 123.8\left(\mathrm{CH}_{1} \mathrm{C5}^{\prime}\right), 126.9(\mathrm{CH}, \mathrm{C} 2), 129.4(\mathrm{CH}$, C4), $131.0\left(\mathrm{CH}, \mathrm{C}^{\prime}\right), 135.2\left(\mathrm{C}, \mathrm{C}^{\prime}\right), 143.8(\mathrm{CH}, \mathrm{C} 6), 144.6\left(\mathrm{CH}, \mathrm{C}^{\prime}\right.$ or $\left.\mathrm{C}^{\prime}\right), 147.1\left(\mathrm{CH}, \mathrm{C}^{\prime}\right.$ or $\left.\mathrm{C6}^{\prime}\right), 147.5(\mathrm{C}, \mathrm{Ca})$. The NMR data are as reported [94]. 


\subsubsection{1-(2-Pyridyl)-7-azaindole (1i)}

The general procedure 3 (reaction time: $48 \mathrm{~h}$ ) and 4 (24 h) using 2-bromopyridine (110 and $95 \mu \mathrm{L}$, respectively) afforded, after recrystallization from heptane, the title product in $75 \%$ and $35 \%$ yield, respectively, as a white solid. Mp 66-68 ${ }^{\circ} \mathrm{C}$, IR: 723, 765, 776, 799, 894, $969,1050,1071,1141,1208,1238,1264,1303,1322,1367,1417,1440,1468,1477,1518,1587$, 3014, 3054, 3107, 3151. ${ }^{1} \mathrm{H}-\mathrm{NMR}\left(\mathrm{CDCl}_{3}\right): 6.64(\mathrm{~d}, 1 \mathrm{H}, J=3.9 \mathrm{~Hz}, \mathrm{H} 3), 7.15(\mathrm{ddd}, 1 \mathrm{H}, J=7.0$, 4.9 and $\left.1.0 \mathrm{~Hz}, \mathrm{H} 5^{\prime}\right), 7.16(\mathrm{dd}, 1 \mathrm{H}, J=7.8$ and $4.8 \mathrm{~Hz}, \mathrm{H} 5), 7.86(\mathrm{ddd}, 1 \mathrm{H}, J=8.4,7.4$ and $\left.2.0 \mathrm{~Hz}, \mathrm{H} 4^{\prime}\right), 7.95(\mathrm{dd}, 1 \mathrm{H}, J=7.8$ and $1.6 \mathrm{~Hz}, \mathrm{H} 4), 8.38(\mathrm{~d}, 1 \mathrm{H}, J=3.9 \mathrm{~Hz}, \mathrm{H} 2), 8.40(\mathrm{dd}, 1 \mathrm{H}$, $J=4.8$ and $1.6 \mathrm{~Hz}, \mathrm{H} 6), 8.49\left(\mathrm{ddd}, 1 \mathrm{H}, J=4.8,1.8\right.$ and $\left.0.7 \mathrm{~Hz}, \mathrm{H6}^{\prime}\right), 8.92(\mathrm{~d}, 1 \mathrm{H}, J=8.4 \mathrm{~Hz}$, $\left.\mathrm{H}^{\prime}\right) .{ }^{13} \mathrm{C}-\mathrm{NMR}\left(\mathrm{CDCl}_{3}\right): 102.7(\mathrm{CH}, \mathrm{C} 3), 115.9\left(\mathrm{CH}, \mathrm{C3}^{\prime}\right), 117.3(\mathrm{CH}, \mathrm{C} 5), 120.5\left(\mathrm{CH}, \mathrm{C}^{\prime}\right)$, $123.5(\mathrm{C}, \mathrm{Cb}), 126.6(\mathrm{CH}, \mathrm{C} 2), 129.2(\mathrm{CH}, \mathrm{C} 4), 138.4\left(\mathrm{CH}, \mathrm{C} 4^{\prime}\right), 143.2(\mathrm{CH}, \mathrm{C} 6), 147.7(\mathrm{C}$, $\mathrm{Ca}), 148.4\left(\mathrm{CH}, \mathrm{C}^{\prime}\right), 150.9\left(\mathrm{C}, \mathrm{C}^{\prime}\right)$. The NMR data are as reported [95]. Crystal data for 1i. $\mathrm{C}_{12} \mathrm{H}_{9} \mathrm{~N}_{3}, M=195.22, T=150(2) \mathrm{K}$, monoclinic, $P 22_{1} / c, a=13.861(2), b=8.2717(10)$, $c=16.721(3) \AA, \beta=104.205(5)^{\circ}, V=1858.5(5) \AA^{3}, Z=8, d=1.395 \mathrm{~g} \mathrm{~cm}^{-3}, \mu=0.087 \mathrm{~mm}^{-1}$. A final refinement on $F^{2}$ with 4242 unique intensities and 271 parameters converged at $\omega R\left(F^{2}\right)=0.1142(R(F)=0.0611)$ for 2520 observed reflections with $I>2 \sigma(I)$. CCDC 2109689 .

\subsubsection{1-(4-Pyridyl)-7-azaindole (1j)}

The general procedure 4 (reaction time: $24 \mathrm{~h}$ ) using 4-bromopyridine $(0.16 \mathrm{~g})$ afforded (eluent: petroleum heptane-EtOAc- $\mathrm{Et}_{3} \mathrm{~N}$ 79:20:1) the title product in $35 \%$ yield as a yellow solid. Mp $90^{\circ} \mathrm{C}$, IR: 709, 765, 775, 798, 821, 893, 994, 1112, 1151, 1199, 1222, 1246, 1268, 1331, 1366, 1420, 1474, 1505, 1521, 1587, 2853, 2925, 3033, 3105. ${ }^{1} \mathrm{H}-\mathrm{NMR}\left(300 \mathrm{MHz}, \mathrm{CDCl}_{3}\right) \delta 6.70$ $(\mathrm{d}, 1 \mathrm{H}, J=3.8 \mathrm{~Hz}, \mathrm{H} 3), 7.19(\mathrm{dd}, 1 \mathrm{H}, J=7.8$ and $4.7 \mathrm{~Hz}, \mathrm{H} 5), 7.62(\mathrm{~d}, 1 \mathrm{H}, J=3.8 \mathrm{~Hz}, \mathrm{H} 2), 7.96$ $(\mathrm{dd}, 1 \mathrm{H}, J=7.8$ and $1.6 \mathrm{~Hz}, \mathrm{H} 4), 8.01\left(\mathrm{~d}, 2 \mathrm{H}, J=6.2 \mathrm{~Hz}, \mathrm{H}^{\prime}\right.$ and $\left.\mathrm{H}^{\prime}\right), 8.41(\mathrm{dd}, 1 \mathrm{H}, J=4.7$ and $\left.1.6 \mathrm{~Hz}, \mathrm{H6}), 8.70\left(\mathrm{br} \mathrm{s}, 2 \mathrm{H}, \mathrm{H} 2{ }^{\prime} \text { and } \mathrm{H}^{\prime}\right)^{\prime}\right) .{ }^{13} \mathrm{C}-\mathrm{NMR}\left(75 \mathrm{MHz}, \mathrm{CDCl}_{3}\right) \delta 104.3(\mathrm{CH}, \mathrm{C} 3)$, $116.2\left(2 \mathrm{CH}, \mathrm{C}^{\prime}\right.$ and $\left.\mathrm{C}^{\prime}\right), 117.9(\mathrm{CH}, \mathrm{C} 5), 122.7(\mathrm{C}, \mathrm{Cb}), 125.7(\mathrm{CH}, \mathrm{C} 2), 129.6(\mathrm{CH}, \mathrm{C} 4)$, $144.0(\mathrm{CH}, \mathrm{C} 6), 145.8\left(\mathrm{C}, \mathrm{C}^{\prime}\right), 148.0(\mathrm{C}, \mathrm{Ca}), 150.6\left(2 \mathrm{CH}, \mathrm{C}^{\prime}\right.$ and $\left.\mathrm{C}^{\prime}\right)$. The NMR data are as reported [30]. Crystal data for $\mathbf{1 j}$. $\mathrm{C}_{12} \mathrm{H}_{9} \mathrm{~N}_{3}, M=195.22, T=150(2) \mathrm{K}$, orthorhombic, $P 22_{1} 2_{1}$ $2_{1}, a=6.8590(4), b=10.3076(6), c=13.2404(6) \AA, V=936.09(9) \AA^{3}, Z=4, d=1.385 \mathrm{~g} \mathrm{~cm}^{-3}$, $\mu=0.086 \mathrm{~mm}^{-1}$. A final refinement on $F^{2}$ with 2133 unique intensities and 137 parameters converged at $\omega R\left(F^{2}\right)=0.0774(R(F)=0.0315)$ for 2018 observed reflections with $I>2 \sigma(I)$. CCDC 2109690.

\subsubsection{1,1'-(1,3-Phenylene)bis(7-azaindole) (2k)}

The general procedure 3 (reaction time: $4 \mathrm{~d}$ ) and $4(5 \mathrm{~d})$ using 1,3-diiodobenzene $(0.20$ and $0.16 \mathrm{~g}$, respectively) afforded (eluent: heptane-EtOAc 90:10) the title product in 40 and $15 \%$ yield, respectively, as a white solid. Mp $110^{\circ} \mathrm{C}$, IR: 688, 719, 750, 774, 796, 874, 894, 1111, 1136, 1155, 1210, 1224, 1247, 1273, 1290, 1316, 1331, 1354, 1418, 1467, 1483, 1494, 1514, 1591, 1608, 1728, 2930, 3015, 3046, 3100. ${ }^{1} \mathrm{H}-\mathrm{NMR}\left(\mathrm{CDCl}_{3}\right): 6.63(\mathrm{~d}, 2 \mathrm{H}, J=3.7 \mathrm{~Hz}, \mathrm{H} 3), 7.13(\mathrm{dd}$, $2 \mathrm{H}, J=7.8$ and $4.7 \mathrm{~Hz}, \mathrm{H} 5), 7.59(\mathrm{~d}, 2 \mathrm{H}, J=3.7 \mathrm{~Hz}, \mathrm{H} 2), 7.64\left(\mathrm{dd}, 1 \mathrm{H}, J=8.8\right.$ and $\left.7.3 \mathrm{~Hz}, \mathrm{H} 5^{\prime}\right)$, 7.76-7.79 (m, 2H, H4 ${ }^{\prime}$ and $\left.\mathrm{H}^{\prime}\right), 7.96(\mathrm{dd}, 2 \mathrm{H}, J=7.8$ and $1.6 \mathrm{~Hz}, \mathrm{H} 4), 8.33(\mathrm{t}, 1 \mathrm{H}, J=2.0 \mathrm{~Hz}$, $\left.\mathrm{H} 2^{\prime}\right), 8.40(\mathrm{dd}, 2 \mathrm{H}, J=4.7$ and $1.6 \mathrm{~Hz}, \mathrm{H} 6) .{ }^{13} \mathrm{C}-\mathrm{NMR}\left(\mathrm{CDCl}_{3}\right): 102.0(2 \mathrm{CH}, \mathrm{C} 3), 116.9(2 \mathrm{CH}$, C5), $119.2(\mathrm{CH}), 121.3\left(2 \mathrm{CH}, \mathrm{C}^{\prime}\right.$ and $\left.\mathrm{C}^{\prime}\right), 121.8(2 \mathrm{C}, \mathrm{Cb}), 127.7(2 \mathrm{CH}, \mathrm{C} 2), 129.1(2 \mathrm{CH}$, C4), $130.1(\mathrm{CH}), 139.4\left(2 \mathrm{C}, \mathrm{Cl}^{\prime}\right.$ and $\left.\mathrm{C}^{\prime}\right), 143.6(2 \mathrm{CH}, \mathrm{C} 6), 147.6(2 \mathrm{C}, \mathrm{Ca})$. These data are as reported [96]. Crystal data for $\mathbf{2 k} . \mathrm{C}_{20} \mathrm{H}_{14} \mathrm{~N}_{4}, M=310.35, T=295 \mathrm{~K}$, orthorhombic, $P 2_{1} 2_{1} 2_{1}$, $a=7.4379(5), b=9.7143(7), c=21.0654(12) \AA, V=1522.06(17) \AA^{3}, Z=4, d=1.354 \mathrm{~g} \mathrm{~cm}^{-3}$, $\mu=0.083 \mathrm{~mm}^{-1}$. A final refinement on $F^{2}$ with 3431 unique intensities and 217 parameters converged at $\omega R\left(F^{2}\right)=0.1108(R(F)=0.0447)$ for 2976 observed reflections with $I>2 \sigma(I)$. CCDC 2109691.

\subsubsection{1-(3-Iodophenyl)-7-azaindole (2k')}

It was obtained in the above reaction in $20 \%$ yield by using the general procedure 3 or 4, as a yellow oil. IR: 658, 682, 717, 730, 772, 796, 870, 893, 963, 994, 1040, 1060, 1075, 1091, $1111,1148,1170,1209,1235,1262,1278,1323,1354,1414,1431,1479,1514,1583,1660,1727$, 
1860, 1925, 2415, 2474, 2563, 2853, 2924, 3017, 3053, 3099. ${ }^{1} \mathrm{H}-\mathrm{NMR}\left(\mathrm{CDCl}_{3}\right): 6.61(\mathrm{~d}, 1 \mathrm{H}$, $J=3.7 \mathrm{~Hz}, \mathrm{H} 3), 7.13(\mathrm{dd}, 1 \mathrm{H}, J=7.8$ and $4.7 \mathrm{~Hz}, \mathrm{H} 5), 7.20\left(\mathrm{t}, 1 \mathrm{H}, J=8.0 \mathrm{~Hz}, \mathrm{H} 5^{\prime}\right), 7.44(\mathrm{~d}$, $1 \mathrm{H}, J=3.7 \mathrm{~Hz}, \mathrm{H} 2), 7.64\left(\mathrm{ddd}, 1 \mathrm{H}, J=7.9,1.5\right.$ and $1.0 \mathrm{~Hz}, \mathrm{H}^{\prime}{ }^{\prime}$ or $\left.\mathrm{H}^{\prime}{ }^{\prime}\right), 7.81(\mathrm{ddd}, 1 \mathrm{H}, J=8.1$, 2.1 and $0.9 \mathrm{~Hz}, \mathrm{H}^{\prime}$ or $\left.\mathrm{H6}^{\prime}\right), 7.94(\mathrm{dd}, 1 \mathrm{H}, J=7.8$ and $1.6 \mathrm{~Hz}, \mathrm{H} 4), 8.15(\mathrm{t}, 1 \mathrm{H}, J=1.9 \mathrm{~Hz}$, $\left.\mathrm{H}^{\prime}{ }^{\prime}\right), 8.39(\mathrm{dd}, 1 \mathrm{H}, \mathrm{J}=4.7$ and $1.6 \mathrm{~Hz}, \mathrm{H} 6) .{ }^{13} \mathrm{C}-\mathrm{NMR}\left(\mathrm{CDCl}_{3}\right): 94.3\left(\mathrm{C}, \mathrm{C}^{\prime}, \mathrm{C}-\mathrm{I}\right), 102.3(\mathrm{CH}$, C3), $117.0(\mathrm{CH}, \mathrm{C} 5), 121.6(\mathrm{C}, \mathrm{Cb}), 123.0(\mathrm{CH}), 127.3(\mathrm{CH}), 129.2(\mathrm{CH}, \mathrm{C} 4), 130.7(\mathrm{CH}), 132.4$ $(\mathrm{CH}), 135.1(\mathrm{CH}), 139.5\left(\mathrm{C}, \mathrm{Cl}^{\prime}\right), 143.7(\mathrm{CH}, \mathrm{C} 6), 147.4(\mathrm{C}, \mathrm{Ca})$. Anal. Calc. for $\mathrm{C}_{13} \mathrm{H}_{9} \mathrm{IN}_{2}$ (320.13): C 48.77, H 2.83, N 8.75. Found: C 48.46, H 3.11, N 8.83.

\subsubsection{1,1'-(1,4-Phenylene)bis(7-azaindole) (21)}

In Ref. [97], The general procedure 1 (reaction time: $5 \mathrm{~d}$ ) and 3 (reaction time: $3 \mathrm{~d}$ ) using 1,4-diiodobenzene ( 0.16 and $0.20 \mathrm{~g}$, respectively) afforded (eluent: petroleum etherEtOAc 90:10) the title product in $0 \%$ and $80 \%$ yield, respectively, as a beige solid. Mp $194{ }^{\circ} \mathrm{C}$, IR: 660, 715, 725, 762, 772, 794, 834, 893, 929, 953, 1045, 1072, 1114, 1131, 1155, $1200,1240,1264,1290,1324,1341,1358,1416,1474,1520,1573,1594,1727,1890,2570$, 3049, 3078, 3102. ${ }^{1} \mathrm{H}-\mathrm{NMR}\left(300 \mathrm{MHz}, \mathrm{CDCl}_{3}\right) \delta 6.67(\mathrm{~d}, 2 \mathrm{H}, \mathrm{J}=3.6 \mathrm{~Hz}, \mathrm{H} 3), 7.16(\mathrm{dd}, 2 \mathrm{H}$, $J=7.8$ and $4.7 \mathrm{~Hz}, \mathrm{H} 5), 7.56(\mathrm{~d}, 2 \mathrm{H}, J=3.6 \mathrm{~Hz}, \mathrm{H} 2), 7.92(\mathrm{~s}, 4 \mathrm{H}, \mathrm{Ph}), 8.00(\mathrm{dd}, 2 \mathrm{H}, J=7.8$ and $1.6 \mathrm{~Hz}, \mathrm{H} 4), 8.40(\mathrm{dd}, 2 \mathrm{H}, J=4.7$ and $1.6 \mathrm{~Hz}, \mathrm{H} 6) .{ }^{13} \mathrm{C}-\mathrm{NMR}\left(75 \mathrm{MHz}, \mathrm{CDCl}_{3}\right) \delta$ 102.0 (2CH, C3), 117.0 (2CH, C5), 121.7 (2C, Cb), 125.1 (4CH, Ph), 127.9 (2CH, C2), 129.3 (2CH, C4), $136.6\left(2 \mathrm{C}, \mathrm{C1}^{\prime}\right), 143.8(2 \mathrm{CH}, \mathrm{C} 6), 147.7(2 \mathrm{C}, \mathrm{Ca})$. Crystal data for $21 . \mathrm{C}_{20} \mathrm{H}_{14} \mathrm{~N}_{4}$, $M=310.35, T=150(2) \mathrm{K}$, orthorhombic, $P_{c} a b, a=8.9954(6), b=9.9118(5), c=16.4444(11) \AA$, $V=1466.19(16) \AA^{3}, Z=4, d=1.406 \mathrm{~g} \mathrm{~cm}^{-3}, \mu=0.087 \mathrm{~mm}^{-1}$. A final refinement on $F^{2}$ with 1683 unique intensities and 109 parameters converged at $\omega R\left(F^{2}\right)=0.0995(R(F)=0.0467)$ for 1192 observed reflections with $I>2 \sigma(I)$. CCDC 2109692.

\subsection{Deprotometalation-Iodolysis of the Different 1-Arylated 7-azaindoles 3.5.1. General Procedure 6}

This was adapted from a reported protocol [52]. The base was prepared from LiTMP [in situ generated by adding $n$-BuLi (about $1.6 \mathrm{M}$ hexanes solution, $3.0 \mathrm{mmol}$ ) to a stirred, cooled $\left(0{ }^{\circ} \mathrm{C}\right)$ solution of 2,2,6,6-tetramethylpiperidine $(0.50 \mathrm{~mL}, 3.0 \mathrm{mmol})$ in THF $\left.(5 \mathrm{~mL})\right]$ and $\mathrm{ZnCl}_{2} \cdot$ TMEDA $(0.26 \mathrm{~g}, 1.0 \mathrm{mmol})$, which was added $5 \mathrm{~min}$ later. The mixture was stirred for $15 \mathrm{~min}$ at $0{ }^{\circ} \mathrm{C}$ before introduction of the substrate $(1.0 \mathrm{mmol})$ at $0-10{ }^{\circ} \mathrm{C}$. After $2 \mathrm{~h}$ at $\mathrm{rt}$, iodolysis was performed by adding a solution of $\mathrm{I}_{2}(0.76 \mathrm{~g}, 3.0 \mathrm{mmol})$ in THF ( $8 \mathrm{~mL})$. The mixture was stirred overnight before addition of an aqueous saturated solution of $\mathrm{Na}_{2} \mathrm{~S}_{2} \mathrm{O}_{3}(10 \mathrm{~mL})$ and extraction with EtOAc $(3 \times 40 \mathrm{~mL})$. The combined organic layers were dried over $\mathrm{MgSO}_{4}$ and concentrated under reduced pressure. Purification by chromatography on silica gel (the eluent is given in the product description) led to the iodinated derivative.

\subsubsection{2-Iodo-1-phenyl-7-azaindole (3a)}

The general procedure 6 from 1-phenyl-7-azaindole (1a; $0.19 \mathrm{~g})$ afforded (eluent: heptane-Et $\left.{ }_{2} \mathrm{O} 70: 30\right)$ the title product in 75\% yield as a white solid. Mp $120{ }^{\circ} \mathrm{C}, \mathrm{IR}: 693,755$, 801, 967, 1109, 1268, 1307, 1339, 1413, 1451, 1498, 1567, 1589, 3054. ${ }^{1} \mathrm{H}-\mathrm{NMR}\left(\mathrm{CDCl}_{3}\right): 6.95$ (s, 1H, H3), $7.07(\mathrm{dd}, 1 \mathrm{H}, \mathrm{J}=7.8$ and $4.8 \mathrm{~Hz}, \mathrm{H} 5), 7.38-7.42(\mathrm{~m}, 2 \mathrm{H}, \mathrm{Ph}), 7.40-7.60(\mathrm{~m}, 3 \mathrm{H}$, $\mathrm{Ph}), 7.88(\mathrm{dd}, 1 \mathrm{H}, J=7.8$ and $1.6 \mathrm{~Hz}, \mathrm{H} 4), 8.23(\mathrm{dd}, 1 \mathrm{H}, J=4.8$ and $1.6 \mathrm{~Hz}, \mathrm{H} 6) .{ }^{13} \mathrm{C}-\mathrm{NMR}$ $\left(\mathrm{CDCl}_{3}\right): 86.0(\mathrm{C}, \mathrm{C} 2, \mathrm{C}-\mathrm{I}), 111.9(\mathrm{CH}, \mathrm{C} 3), 116.9(\mathrm{CH}, \mathrm{C} 5), 122.2(\mathrm{C}, \mathrm{Cb}), 127.4\left(\mathrm{CH}, \mathrm{C}^{\prime}\right)$, 128.9 (CH, C4), 129.3 (2CH, Ph), 129.4 (2CH, Ph), 137.7 (C, C1' ), 143.9 (CH, C6), 149.8 (C, Ca). Crystal data for 3a. $\mathrm{C}_{13} \mathrm{H}_{9} \mathrm{IN}_{2}, M=320.12, T=150(2) \mathrm{K}$, monoclinic, $P 2_{1} / c, a=10.4501$ (4), $b=5.6326(3), c=19.4738(8) \AA, \beta=94.859(2)^{\circ}, V=1142.13(9) \AA^{3}, Z=4, d=1.862 \mathrm{~g} \mathrm{~cm}^{-3}$, $\mu=2.775 \mathrm{~mm}^{-1}$. A final refinement on $F^{2}$ with 2626 unique intensities and 145 parameters converged at $\omega R\left(F^{2}\right)=0.0453(R(F)=0.0232)$ for 2269 observed reflections with $I>2 \sigma(I)$. CCDC 2109693. 


\subsubsection{2-Iodo-1-(2-iodophenyl)-7-azaindole ( $\left.3 \mathbf{a}^{\prime}\right)$}

It was obtained in the above reaction in $5 \%$ yield as a yellow solid. IR: 694, 728, 758, 783, 801, 906, 1109, 1267, 1306, 1339, 1358, 1407, 1456, 1496, 1573, 1588, 1604, 2224, 2926, 3058. ${ }^{1} \mathrm{H}-\mathrm{NMR}\left(\mathrm{CDCl}_{3}\right): 6.99(\mathrm{~s}, 1 \mathrm{H}, \mathrm{H} 3), 7.08(\mathrm{dd}, 1 \mathrm{H}, J=7.9$ and $4.8 \mathrm{~Hz}, \mathrm{H} 5), 7.26(\mathrm{td}, 1 \mathrm{H}$, $J=7.7$ and $1.7 \mathrm{~Hz}, \mathrm{H} 4^{\prime}$ or $\left.\mathrm{H}^{\prime}{ }^{\prime}\right), 7.37\left(\mathrm{dd}, 1 \mathrm{H}, J=7.8\right.$ and $1.6 \mathrm{~Hz}, \mathrm{H}^{\prime}$ or $\left.\mathrm{H} 6^{\prime}\right), 7.56(\mathrm{td}, 1 \mathrm{H}$, $J=7.6$ and $1.4 \mathrm{~Hz}, \mathrm{H} 4^{\prime}$ or $\left.\mathrm{H}^{\prime}\right), 7.90(\mathrm{dd}, 1 \mathrm{H}, J=7.8$ and $1.6 \mathrm{~Hz}, \mathrm{H} 4), 8.03(\mathrm{dd}, 1 \mathrm{H}, J=8.0$ and $1.3 \mathrm{~Hz}, \mathrm{H}^{\prime}$ or $\left.\mathrm{H}^{\prime}\right), 8.24(\mathrm{dd}, 1 \mathrm{H}, J=4.8$ and $1.6 \mathrm{~Hz}, \mathrm{H} 6) .{ }^{13} \mathrm{C}-\mathrm{NMR}\left(\mathrm{CDCl}_{3}\right): 85.8(\mathrm{C}, \mathrm{C} 2$, C-I), 101.1 (C, C2', C-I), $111.8(\mathrm{CH}, \mathrm{C} 3), 117.0(\mathrm{CH}, \mathrm{C} 5), 122.3(\mathrm{C}, \mathrm{Cb}), 127.6(\mathrm{CH}), 129.4(\mathrm{CH}$, C4), $131.2(\mathrm{CH}), 131.4(\mathrm{CH}), 140.0\left(\mathrm{CH}, \mathrm{C3}^{\prime}\right), 141.0\left(\mathrm{C}, \mathrm{Cl}^{\prime}\right), 144.2(\mathrm{CH}, \mathrm{C} 6), 149.6(\mathrm{C}, \mathrm{Ca})$. Crystal data for $3 \mathbf{a}^{\prime} . \mathrm{C}_{13} \mathrm{H}_{8} \mathrm{I}_{2} \mathrm{~N}_{2}, M=446.01, T=150(2) \mathrm{K}$, monoclinic, $P 2_{1} / n, a=7.2949(12)$, $b=14.380(2), c=12.247(2) \AA, \beta=91.159(8)^{\circ}, V=1284.4(4) \AA^{3}, Z=4, d=2.307 \mathrm{~g} \mathrm{~cm}^{-3}$, $\mu=4.875 \mathrm{~mm}^{-1}$. A final refinement on $F^{2}$ with 2940 unique intensities and 154 parameters converged at $\omega R\left(F^{2}\right)=0.0667(R(F)=0.0293)$ for 2603 observed reflections with $I>2 \sigma(I)$. CCDC 2109694.

\subsubsection{2-Iodo-1-(4-(trifluoromethyl)phenyl)-7-azaindole (3e)}

The general procedure 6 from 1-(4-(trifluoromethyl)phenyl)-7-azaindole (1e; $0.22 \mathrm{~g}$ ) afforded (eluent: petroleum ether-EtOAc 90:10) the title product in 10\% yield as a white solid. Mp 88-90 ${ }^{\circ} \mathrm{C}$. IR: 709, 759, 772, 798, 845, 909, 967, 1019, 1064, 1103, 1122, 1164,1214, 1262, 1320, 1353, 1411, 1456, 1493, 1521, 1570, 1590, 1615, 2963. ${ }^{1} \mathrm{H}-\mathrm{NMR}\left(\mathrm{CDCl}_{3}\right): 7.00$ (s, 1H, H3), $7.10(\mathrm{dd}, 1 \mathrm{H}, J=7.9$ and $4.8 \mathrm{~Hz}, \mathrm{H} 5), 7.59(\mathrm{~d}, 2 \mathrm{H}, J=8.2 \mathrm{~Hz}, \mathrm{Ph}), 7.83(\mathrm{~d}, 2 \mathrm{H}$, $J=8.3 \mathrm{~Hz}, \mathrm{Ph}), 7.90(\mathrm{dd}, 1 \mathrm{H}, J=7.9$ and $1.6 \mathrm{~Hz}, \mathrm{H} 4), 8.23(\mathrm{dd}, 1 \mathrm{H}, J=4.8$ and $1.6 \mathrm{~Hz}, \mathrm{H6})$. ${ }^{13} \mathrm{C}-\mathrm{NMR}\left(\mathrm{CDCl}_{3}\right): 84.5$ (C, C2, C-I), $113.2(\mathrm{CH}, \mathrm{C} 3), 117.5(\mathrm{CH}, \mathrm{C} 5), 122.2(\mathrm{C}, \mathrm{Cb}), 124.0(\mathrm{q}$, $\left.\mathrm{C}, J=272 \mathrm{~Hz}, \mathrm{CF}_{3}\right), 126.5\left(\mathrm{q}, 2 \mathrm{CH}, J=3.7 \mathrm{~Hz}, \mathrm{C}^{\prime}\right.$ and $\left.\mathrm{C}^{\prime}\right), 127.8(\mathrm{CH}, \mathrm{C} 4), 129.7\left(2 \mathrm{CH}, \mathrm{C2}^{\prime}\right.$ and $\left.\mathrm{C}^{\prime}\right), 130.7\left(\mathrm{q}, \mathrm{C}, J=32.8 \mathrm{~Hz}, \mathrm{C4}^{\prime}\right), 140.6\left(\mathrm{C}, \mathrm{C1}^{\prime}\right), 144.1$ (CH, C6), 149.7 (C, Ca). Anal. Calc. for $\mathrm{C}_{14} \mathrm{H}_{8} \mathrm{~F}_{3} \mathrm{IN}_{2}$ (388.13): C 43.32, H 2.08, N 7.22. Found: C 43.58, H 2.15, N 7.12.

\subsubsection{2-Iodo-1-(3-iodo-4-(trifluoromethyl)phenyl)-7-azaindole ( $\left.\mathbf{3} \mathbf{e}^{\prime}\right)$}

It was obtained in the above reaction in $20 \%$ yield as a greenish oil. IR: $715,759,803$, 840, 893, 969, 1075, 1133, 1172, 1268, 1318, 1418, 1457, 1498, 1590. ${ }^{1} \mathrm{H}-\mathrm{NMR}\left(\mathrm{CDCl}_{3}\right): 7.01$ (s, $1 \mathrm{H}, \mathrm{H} 3), 7.11(\mathrm{dd}, 1 \mathrm{H}, J=7.9$ and $4.8 \mathrm{~Hz}, \mathrm{H} 5), 7.48\left(\mathrm{dd}, 1 \mathrm{H}, J=8.2\right.$ and $\left.0.4 \mathrm{~Hz}, \mathrm{H}^{\prime}\right), 7.82$ (ddd, $1 \mathrm{H}, J=8.2,2.0$ and $\left.0.6 \mathrm{~Hz}, \mathrm{H} 5^{\prime}\right), 7.92(\mathrm{dd}, 1 \mathrm{H}, J=7.9$ and $1.6 \mathrm{~Hz}, \mathrm{H} 4), 8.23(\mathrm{dd}, 1 \mathrm{H}$, $J=4.8$ and $1.6 \mathrm{~Hz}, \mathrm{H} 6), 8.27\left(\mathrm{~d}, 1 \mathrm{H}, J=1.4 \mathrm{~Hz}, \mathrm{H} 3^{\prime}\right) .{ }^{13} \mathrm{C}-\mathrm{NMR}\left(\mathrm{CDCl}_{3}\right): 84.5(\mathrm{C}, \mathrm{C} 2, \mathrm{C}-\mathrm{I})$, 101.2 (C, C2', C-I), $112.6(\mathrm{CH}, \mathrm{C} 3), 117.4(\mathrm{CH}, \mathrm{C} 5), 122.4(\mathrm{C}, \mathrm{Cb}), 122.7$ (q, C, J = 273 Hz, $\left.\mathrm{CF}_{3}\right), 126.5\left(\mathrm{q}, \mathrm{CH}, J=3.5 \mathrm{~Hz}, \mathrm{C}^{\prime}\right), 127.8(\mathrm{CH}, \mathrm{C} 4), 131.8\left(\mathrm{CH}, \mathrm{C6}^{\prime}\right), 133.0(\mathrm{q}, \mathrm{C}, J=33.3 \mathrm{~Hz}$, $\left.\mathrm{C}^{\prime}\right), 137.0\left(\mathrm{q}, \mathrm{CH}, J=3.7 \mathrm{~Hz}, \mathrm{C}^{\prime}\right), 144.3(\mathrm{CH}, \mathrm{C} 6), 144.4\left(\mathrm{C}, \mathrm{d}, J=1.2 \mathrm{~Hz}, \mathrm{Cl}^{\prime}\right), 149.6(\mathrm{C}$, Ca). Anal. Calc. for $\mathrm{C}_{14} \mathrm{H}_{7} \mathrm{~F}_{3} \mathrm{I}_{2} \mathrm{~N}_{2}$ (514.03): C 32.71, H 1.37, N 5.45. Found: C 32.83, H 1.25, N 5.20.

\subsubsection{1-(3,5-Dimethylphenyl)-2-iodo-7-azaindole (3f)}

The general procedure 6 from 1-(3,4-dimethylphenyl)-7-azaindole (1f; $0.22 \mathrm{~g}$ ) afforded (eluent: petroleum ether-EtOAc 90:10) the title product in $40 \%$ yield as a greenish oil. IR: 695, 770, 801, 852, 1038, 1109, 1133, 1175, 1273, 1310, 1339, 1380, 1408, 1457, 1490, 1569, 1588, 2922. ${ }^{1} \mathrm{H}-\mathrm{NMR}\left(\mathrm{CDCl}_{3}\right): 2.41(\mathrm{~d}, 6 \mathrm{H}, J=0.5 \mathrm{~Hz}, \mathrm{Me}), 6.92(\mathrm{~s}, 1 \mathrm{H}, \mathrm{H} 3), 6.99$ (br s, $2 \mathrm{H}, \mathrm{H2}{ }^{\prime}$ and $\left.\mathrm{H}^{\prime}\right), 7.04(\mathrm{dd}, 1 \mathrm{H}, J=7.8$ and $4.8 \mathrm{~Hz}, \mathrm{H} 5), 7.14\left(\mathrm{br} \mathrm{s}, 1 \mathrm{H}, \mathrm{H} 4^{\prime}\right), 7.86(\mathrm{dd}, 1 \mathrm{H}, J=7.8$ and $1.6 \mathrm{~Hz}, \mathrm{H} 4), 8.23(\mathrm{dd}, 1 \mathrm{H}, J=4.7$ and $1.6 \mathrm{~Hz}, \mathrm{H} 6) .{ }^{13} \mathrm{C}-\mathrm{NMR}\left(\mathrm{CDCl}_{3}\right): 21.5\left(2 \mathrm{CH}_{3}, \mathrm{Me}\right), 86.5$ (C, C2, C-I), $111.5(\mathrm{CH}, \mathrm{C} 3), 116.7(\mathrm{CH}, \mathrm{C} 5), 122.2(\mathrm{C}, \mathrm{Cb}), 127.1\left(2 \mathrm{CH}, \mathrm{C2}^{\prime}\right.$ and $\left.\mathrm{C6}^{\prime}\right), 127.3$ $\left(\mathrm{CH}, \mathrm{C} 4\right.$ or $\left.\mathrm{C}^{\prime}\right), 130.9\left(\mathrm{CH}, \mathrm{C} 4\right.$ or $\left.\mathrm{C4}^{\prime}\right), 137.6\left(\mathrm{C}^{\prime} \mathrm{C1}^{\prime}\right), 139.0\left(2 \mathrm{C}, \mathrm{C}^{\prime}\right.$ and $\left.\mathrm{C}^{\prime}\right), 143.9(\mathrm{CH}$, C6), 149.9 (C, Ca). Anal. Calc. for $\mathrm{C}_{15} \mathrm{H}_{13} \mathrm{IN}_{2}$ (348.18): C 51.74, H 3.76, N 8.05. Found: C 51.54, H 4.17, N 8.12.

\subsubsection{1-(5-Iodo-2-thienyl)-7-azaindole (3g)}

The general procedure 6 from 1-(2-thienyl)-7-azaindole (1g; $0.20 \mathrm{~g})$ afforded (eluent: heptane-EtOAc 90:10) the title product in $30 \%$ yield as a white solid. Mp $86^{\circ} \mathrm{C}$. IR: 676 , 
713, 765, 793, 893, 942, 1052, 1133, 1192, 1235, 1270, 1304, 1328, 1354, 1416, 1454, 1473, 1510, 1547, 1577, 1593, 2922, 3052, 3071. ${ }^{1} \mathrm{H}-\mathrm{NMR}\left(\mathrm{CDCl}_{3}\right): 6.59$ (d, 1H, J = $\left.3.7 \mathrm{~Hz}, \mathrm{H3}\right)$, $6.86\left(\mathrm{~d}, 1 \mathrm{H}, \mathrm{J}=3.9 \mathrm{~Hz}, \mathrm{H3}^{\prime}\right.$ or $\left.\mathrm{H}^{\prime}\right), 7.14(\mathrm{dd}, 1 \mathrm{H}, J=7.7$ and $4.6 \mathrm{~Hz}, \mathrm{H} 5), 7.17(\mathrm{~d}, 1 \mathrm{H}$, $J=3.9 \mathrm{~Hz}, \mathrm{H}^{\prime}$ or $\left.\mathrm{H}^{\prime}\right), 7.43(\mathrm{~d}, 1 \mathrm{H}, J=3.7 \mathrm{~Hz}, \mathrm{H} 2), 7.91(\mathrm{dd}, 1 \mathrm{H}, J=7.8$ and $1.4 \mathrm{~Hz}$, $\mathrm{H} 4), 8.40(\mathrm{dd}, 1 \mathrm{H}, \mathrm{J}=4.6$ and $1.3 \mathrm{~Hz}, \mathrm{H} 6) .{ }^{13} \mathrm{C}-\mathrm{NMR}\left(\mathrm{CDCl}_{3}\right): 68.4\left(\mathrm{C}, \mathrm{C} 5^{\prime}, \mathrm{C}-\mathrm{I}\right), 102.9$ $(\mathrm{CH}, \mathrm{C} 3), 117.3\left(\mathrm{CH}, \mathrm{C} 5\right.$ or $\left.\mathrm{C}^{\prime}\right), 117.6\left(\mathrm{CH}, \mathrm{C} 5\right.$ or $\left.\mathrm{C}^{\prime}\right), 121.2(\mathrm{C}, \mathrm{Cb}), 127.1(\mathrm{CH}, \mathrm{C} 2)$, 129.3 (CH, C4), $134.9\left(\mathrm{CH}, \mathrm{C4}^{\prime}\right), 143.8$ (CH, C6), 144.2 (C, C2'), 146.9 (C, Ca). Crystal data for $3 \mathrm{~g} . \mathrm{C}_{11} \mathrm{H}_{7} \mathrm{IN}_{2} \mathrm{~S}, M=326.15, T=295(2) \mathrm{K}$, orthorhombic, $P 22_{1} 2_{1} 21, a=4.1711(7)$, $b=11.5731(17), c=22.327(3) \AA, V=1077.8(3) \AA^{3}, Z=4, d=2.010 \mathrm{~g} \mathrm{~cm}^{-3}, \mu=3.129 \mathrm{~mm}^{-1}$. A final refinement on $F^{2}$ with 2450 unique intensities and 137 parameters converged at $\omega R\left(F^{2}\right)=0.1127(R(F)=0.0498)$ for 1939 observed reflections with $I>2 \sigma(I)$. CCDC 2109695 .

\subsubsection{2-Iodo-1-(5-iodo-2-thienyl)-7-azaindole ( $\left.\mathbf{~ g}^{\prime}\right)$}

It was obtained in the above reaction in $40 \%$ yield as a yellow solid. Mp $152-154{ }^{\circ} \mathrm{C}$. IR: $675,735,759,790,802,897,914,946,1044,1108,1176,1208,1260,1292,1309,1337$, 1400, 1434, 1456, 1493, 1550,1573, 1590, 3059. ${ }^{1} \mathrm{H}-\mathrm{NMR}\left(\mathrm{CDCl}_{3}\right): 6.83(\mathrm{~d}, 1 \mathrm{H}, J=3.9 \mathrm{~Hz}$, $\mathrm{H}^{\prime}$ or $\left.\mathrm{H}^{\prime}{ }^{\prime}\right), 6.95(\mathrm{~s}, 1 \mathrm{H}, \mathrm{H} 3), 7.10(\mathrm{dd}, 1 \mathrm{H}, J=7.8$ and $4.8 \mathrm{~Hz}, \mathrm{H} 5), 7.34(\mathrm{~d}, 1 \mathrm{H}, J=3.9 \mathrm{~Hz}$, $\mathrm{H}^{\prime}$ or $\left.\mathrm{H}^{\prime}\right), 7.86(\mathrm{dd}, 1 \mathrm{H}, J=7.8$ and $1.6 \mathrm{~Hz}, \mathrm{H} 4), 8.27(\mathrm{dd}, 1 \mathrm{H}, J=4.8$ and $1.6 \mathrm{~Hz}, \mathrm{H} 6)$. ${ }^{13} \mathrm{C}-\mathrm{NMR}\left(\mathrm{CDCl}_{3}\right): 74.5$ (C, C5', C-I), 87.7 (C, C2, C-I), 112.8 (CH, C3), $117.4(\mathrm{CH}, \mathrm{C} 5), 122.1$ $(\mathrm{C}, \mathrm{Cb}), 127.5\left(\mathrm{CH}, \mathrm{C}^{\prime}\right), 129.4(\mathrm{CH}, \mathrm{C} 4), 135.5\left(\mathrm{CH}, \mathrm{C}^{\prime}\right), 142.3\left(\mathrm{C}, \mathrm{C}^{\prime}\right), 144.0(\mathrm{CH}, \mathrm{C} 6)$, 150.1 (C, Ca). Crystal data for $3 \mathbf{g}^{\prime} . \mathrm{C}_{11} \mathrm{H}_{6} \mathrm{I}_{2} \mathrm{~N}_{2} \mathrm{~S}, M=452.04, \mathrm{~T}=150(2) \mathrm{K}$, triclinic, $P-1$, $a=5.4889(3), b=10.8313(6), c=10.9361(6) \AA, \alpha=84.984(3), \beta=77.554(3), \gamma=78.838(3)^{\circ}$, $V=622.17(6) \AA^{3}, Z=2, d=2.413 \mathrm{~g} \mathrm{~cm}^{-3}, \mu=5.195 \mathrm{~mm}^{-1}$. A final refinement on $F^{2}$ with 2822 unique intensities and 145 parameters converged at $\omega R\left(F^{2}\right)=0.0529(R(F)=0.0225)$ for 2610 observed reflections with $I>2 \sigma(I)$. CCDC 2109696.

\subsubsection{2-Iodo-1-(3-(7-aza-1-indolyl)phenyl)-7-azaindole (3k)}

The general procedure 6 from 1,1'-(1,3-phenylene)bis(7-azaindole) (2k; $0.31 \mathrm{~g})$ afforded (eluent: heptane-EtOAc 70:30) the title product in about $20 \%$ yield. It was identified by NMR: ${ }^{1} \mathrm{H}-\mathrm{NMR}\left(\mathrm{CDCl}_{3}\right): 6.64\left(\mathrm{~d}, J=3.7 \mathrm{~Hz}, 1 \mathrm{H}, \mathrm{H}^{\prime}\right), 6.98(\mathrm{~s}, 1 \mathrm{H}, \mathrm{H} 3), 7.08(\mathrm{dd}, 1 \mathrm{H}, J=7.9$ and $4.8 \mathrm{~Hz}, \mathrm{H} 5), 7.14\left(\mathrm{dd}, 1 \mathrm{H}, J=7.8\right.$ and $\left.4.7 \mathrm{~Hz}, \mathrm{H}^{\prime}\right), 7.39(\mathrm{ddd}, 1 \mathrm{H}, J=7.9,2.0$ and 1.0 $\mathrm{Hz}, \mathrm{H}^{\prime \prime}$ or $\left.\mathrm{H6}^{\prime \prime}\right), 7.61\left(\mathrm{~d}, 1 \mathrm{H}, J=3.7 \mathrm{~Hz}, \mathrm{H} 2^{\prime}\right), 7.71\left(\mathrm{t}, 1 \mathrm{H}, J=8.1 \mathrm{~Hz}, \mathrm{H} 5^{\prime \prime}\right), 7.85(\mathrm{t}, 1 \mathrm{H}$, $\left.J=2.0 \mathrm{~Hz}, \mathrm{H} 2^{\prime \prime}\right), 7.89(\mathrm{dd}, 1 \mathrm{H} J=7.9$ and $1.6 \mathrm{~Hz}, \mathrm{H} 4), 7.96\left(\mathrm{dd}, 1 \mathrm{H}, J=7.8\right.$ and $1.6 \mathrm{~Hz}, \mathrm{H}^{\prime}{ }^{\prime}$ ), $8.13\left(\mathrm{ddd}, 1 \mathrm{H}, J=8.2,2.1\right.$ and $1.0 \mathrm{~Hz}, \mathrm{H} 4{ }^{\prime \prime}$ or H6"), $8.24(\mathrm{dd}, 1 \mathrm{H}, J=4.7$ and $1.6 \mathrm{~Hz}, \mathrm{H6}$ ), $8.38\left(\mathrm{dd}, 1 \mathrm{H}, J=4.7\right.$ and $\left.1.6 \mathrm{~Hz}, \mathrm{H6}^{\prime}\right)$. Anal. Calc. for $\mathrm{C}_{20} \mathrm{H}_{13} \mathrm{IN}_{4}$ (436.26): C 55.06, $\mathrm{H} 3.00$, N 12.84. Found: C 55.17, H 3.08, N 12.33 .

\subsubsection{1,1'-(1,3-Phenylene)bis(2-iodo-7-azaindole) (3k')}

It was obtained in the above reaction in $20 \%$ yield as a beige solid. Mp $182{ }^{\circ} \mathrm{C}$. IR: 693 , 727, 757, 782, 801, 905, 958, 1005, 1040, 1084, 1108, 1173, 1208, 1266, 1306, 1338, 1357, 1406, 1455, 1495, 1572, 1588, 1604, 1725, 1859, 2223, 2551, 2602, 2853, 2926, 3057, 3120, 3420, 3742, 3868. ${ }^{1} \mathrm{H}-\mathrm{NMR}\left(\mathrm{CDCl}_{3}\right): 6.95(\mathrm{~s}, 2 \mathrm{H}, \mathrm{H3}), 7.07(\mathrm{dd}, 2 \mathrm{H}, J=7.8$ and $4.8 \mathrm{~Hz}, \mathrm{H} 5), 7.49(\mathrm{t}, 1 \mathrm{H}$, $\left.J=1.9 \mathrm{~Hz}, \mathrm{H} 2^{\prime}\right), 7.59-7.62\left(\mathrm{~m}, 2 \mathrm{H}, \mathrm{H}^{\prime}{ }^{\prime}\right.$ and $\left.\mathrm{H}^{\prime}\right), 7.75\left(\mathrm{dd}, 1 \mathrm{H}, J=8.6\right.$ and $\left.7.2 \mathrm{~Hz}, \mathrm{H} 5^{\prime}\right), 7.86$ $(\mathrm{dd}, 2 \mathrm{H}, J=7.8$ and $1.6 \mathrm{~Hz}, \mathrm{H} 4), 8.23(\mathrm{dd}, 2 \mathrm{H}, J=4.7$ and $1.6 \mathrm{~Hz}, \mathrm{H} 6) .{ }^{13} \mathrm{C}-\mathrm{NMR}\left(\mathrm{CDCl}_{3}\right)$ : 85.5 (2C, C2, C-I), 112.7 (2CH, C3), 117.3 (2CH, C5), $122.4(2 \mathrm{C}, \mathrm{Cb}), 127.5\left(2 \mathrm{CH}, \mathrm{C}^{\prime}{ }^{\prime}\right.$ and C6 $\left.{ }^{\prime}\right)$, $129.5(2 \mathrm{CH}, \mathrm{C} 4), 129.7\left(\mathrm{CH}, \mathrm{C}^{\prime}\right.$ or $\left.\mathrm{C}^{\prime}\right), 130.3\left(\mathrm{CH}, \mathrm{C}^{\prime}\right.$ or $\left.\mathrm{C}^{\prime}\right), 138.4\left(2 \mathrm{C}, \mathrm{C}^{\prime}\right), 144.0(2 \mathrm{CH}$, C6), 150.0 (2C, Ca). Crystal data for $3 \mathbf{k}^{\prime} . \mathrm{C}_{20} \mathrm{H}_{12} \mathrm{I}_{2} \mathrm{~N}_{4}, M=562.14, T=150(2) \mathrm{K}$, monoclinic, $\mathrm{C}$ $2 / c, a=14.5928(9), b=16.9523(10), c=8.4985(6) \AA, \beta=123.070(3)^{\circ}, V=1761.8(2) \AA^{3}, Z=4$, $d=2.119 \mathrm{~g} \mathrm{~cm}^{-3}, \mu=3.582 \mathrm{~mm}^{-1}$. A final refinement on $F^{2}$ with 2019 unique intensities and 119 parameters converged at $\omega R\left(F^{2}\right)=0.0639(R(F)=0.0281)$ for 1797 observed reflections with $I>2 \sigma(I)$. CCDC 2109697. 


\subsubsection{1,1'-(1-Iodo-2,4-phenylene)bis(2-iodo-7-azaindole (3k')}

It was obtained in the above reaction in $14 \%$ yield as a white solid. Mp $132{ }^{\circ} \mathrm{C}$. IR: 679 , $757,820,1006,1025,1053,1270,1410,1478,1621,2123,2251,3465 .{ }^{1} \mathrm{H}-\mathrm{NMR}\left(\left(\mathrm{CD}_{3}\right)_{2} \mathrm{SO}\right)$ : $7.09(\mathrm{~s}, 2 \mathrm{H}, \mathrm{H} 3), 7.15(\mathrm{dt}, 2 \mathrm{H}, J=7.8$ and $4.7 \mathrm{~Hz}, \mathrm{H} 5), 7.47\left(\mathrm{dd}, 1 \mathrm{H}, J=8.4\right.$ and $\left.2.4 \mathrm{~Hz}, \mathrm{H} 5^{\prime}\right)$, $7.52\left(\mathrm{~d}, 1 \mathrm{H}, J=2.4 \mathrm{~Hz}, \mathrm{H}^{\prime}\right), 8.00(\mathrm{dt}, 2 \mathrm{H}, J=7.8$ and $1.5 \mathrm{~Hz}, \mathrm{H} 4), 8.14(\mathrm{dd}, 1 \mathrm{H}, J=4.7$ and $1.6 \mathrm{~Hz}, \mathrm{H6}), 8.17(\mathrm{dd}, 1 \mathrm{H}, J=4.7$ and $1.6 \mathrm{~Hz}, \mathrm{H6}), 8.26\left(\mathrm{~d}, 1 \mathrm{H}, J=8.4 \mathrm{~Hz}, \mathrm{H6}^{\prime}\right) .{ }^{13} \mathrm{C}-\mathrm{NMR}$ ((CD $\left.)_{2} \mathrm{SO}\right): 88.0$ (C, C2, C-I), 88.7 (C, C2, C-I), 101.9 (C, C1' , C-I ), 111.2 (CH, C3), 112.3 $(\mathrm{CH}, \mathrm{C} 3), 116.9(\mathrm{CH}, \mathrm{C} 5), 117.3(\mathrm{CH}, \mathrm{C} 5), 121.8(\mathrm{C}, \mathrm{Cb}), 121.8(\mathrm{C}, \mathrm{Cb}), 127.4\left(\mathrm{CH}, \mathrm{C}^{\prime}\right.$ or $\left.\mathrm{C}^{\prime}\right), 127.6\left(\mathrm{CH}, \mathrm{C}^{\prime}\right.$ or $\left.\mathrm{C}^{\prime}\right), 131.6(\mathrm{CH}, \mathrm{C} 4), 131.8(\mathrm{CH}, \mathrm{C} 4), 137.9\left(\mathrm{C}, \mathrm{C}^{\prime}\right), 139.3\left(\mathrm{CH}, \mathrm{C}^{\prime}\right)$, $141.3\left(\mathrm{C}, \mathrm{C2}^{\prime}\right), 143.2(\mathrm{CH}, \mathrm{C} 6), 143.3(\mathrm{CH}, \mathrm{C} 6), 149.1$ (C, Ca), 149.2 (C, Ca). Anal. Calc. for $\mathrm{C}_{20} \mathrm{H}_{11} \mathrm{I}_{3} \mathrm{~N}_{4}$ (688.05): C 34.91, H 1.61, N 8.14. Found: C 34.66, H 1.79, N 8.13.

\subsection{Direct Iodination of the Different 1-Arylated 7-Azaindoles}

3.6.1. General Procedure 7

This was inspired from a reported protocol [66]. A mixture of $\mathrm{I}_{2}(0.28 \mathrm{~g}, 1.1 \mathrm{mmol})$, $\mathrm{KOH}(0.17 \mathrm{~g}, 3.0 \mathrm{mmol})$ and 7-azaindole $(1.0 \mathrm{mmol})$ in acetonitrile $(5 \mathrm{~mL})$ was stirred for $12 \mathrm{~h}$ at rt. An aqueous saturated solution of $\mathrm{Na}_{2} \mathrm{~S}_{2} \mathrm{O}_{3}(10 \mathrm{~mL})$ was then added before extraction with EtOAc $(3 \times 40 \mathrm{~mL})$. The combined organic layers were dried over $\mathrm{MgSO}_{4}$ and concentrated under reduced pressure. Purification by chromatography on silica gel (the eluent is given in the product description) led to the iodinated derivative.

\subsubsection{General Procedure 8}

This was inspired from a reported protocol [66]. A mixture of $\mathrm{I}_{2}(0.51 \mathrm{~g}, 2.0 \mathrm{mmol})$, $\mathrm{KOH}(0.17 \mathrm{~g}, 3.0 \mathrm{mmol})$ and 7-azaindole $(1.0 \mathrm{mmol})$ in acetonitrile $(5 \mathrm{~mL})$ was stirred at $40{ }^{\circ} \mathrm{C}$ for $14 \mathrm{~h}$. An aqueous saturated solution of $\mathrm{Na}_{2} \mathrm{~S}_{2} \mathrm{O}_{3}(10 \mathrm{~mL})$ was then added before extraction with EtOAc $(3 \times 40 \mathrm{~mL})$. The combined organic layers were dried over $\mathrm{MgSO}_{4}$ and concentrated under reduced pressure. Purification by chromatography on silica gel (the eluent is given in the product description) led to the iodinated derivative.

\subsubsection{3-Iodo-1-phenyl-7-azaindole (4a)}

The general procedure 7 from 1-phenyl-7-azaindole (1a; $0.19 \mathrm{~g})$ afforded (eluent: heptane-EtOAc 90:10) the title product in 65\% yield as a yellow oil. IR: 690, 727, 753, 763, 790, 924, 979, 1039, 1074, 1110, 1143, 1221, 1270, 1313, 1348, 1409, 1455, 1479, 1497, 1510, 1561, 1591, 3043. ${ }^{1} \mathrm{H}-\mathrm{NMR}\left(\mathrm{CDCl}_{3}\right): 7.21(\mathrm{dd}, 1 \mathrm{H}, J=7.9$ and $4.7 \mathrm{~Hz}, \mathrm{H} 5), 7.35(\mathrm{tt}, 1 \mathrm{H}, J=7.4$ and $\left.1.2 \mathrm{~Hz}, \mathrm{H}^{\prime}\right), 7.48-7.55(\mathrm{~m}, 2 \mathrm{H}, \mathrm{Ph}), 7.61(\mathrm{~s}, 1 \mathrm{H}, \mathrm{H} 2), 7.69-7.73(\mathrm{~m}, 2 \mathrm{H}, \mathrm{Ph}), 7.78(\mathrm{dd}$, $1 \mathrm{H}, J=7.9$ and $1.6 \mathrm{~Hz}, \mathrm{H} 4), 8.39(\mathrm{dd}, 1 \mathrm{H}, J=4.7$ and $1.5 \mathrm{~Hz}, \mathrm{H} 6) .{ }^{13} \mathrm{C}-\mathrm{NMR}\left(\mathrm{CDCl}_{3}\right): 56.6$ (C, C3, C-I), $117.6(\mathrm{CH}, \mathrm{C} 5), 124.0\left(2 \mathrm{CH}, \mathrm{C2}^{\prime}\right.$ and $\left.\mathrm{C6}^{\prime}\right), 124.0(\mathrm{C}, \mathrm{Cb}), 126.9\left(\mathrm{CH}, \mathrm{C}^{\prime}\right), 129.5$ $\left(2 \mathrm{CH}, \mathrm{C}^{\prime}\right.$ and $\left.\mathrm{C5}^{\prime}\right), 129.6(\mathrm{CH}, \mathrm{C} 4), 131.9(\mathrm{CH}, \mathrm{C} 2), 137.7\left(\mathrm{C}, \mathrm{C1}^{\prime}\right), 144.8(\mathrm{CH}, \mathrm{C} 6), 147.1(\mathrm{C}$, Ca). These data are as reported [66].

\subsubsection{3-Iodo-1-(4-methoxyphenyl)-7-azaindole (4b)}

The general procedure 7 from 1-(4-methoxyphenyl)-7-azaindole (1b; $0.22 \mathrm{~g})$ afforded (eluent: heptane-EtOAc 90:10) the title product in $40 \%$ yield as a white solid. Mp $58^{\circ} \mathrm{C}$, IR: 700, 764, 799, 830, 924, 979, 1035, 1109, 1144, 1180,1220, 1247, 1272, 1299, 1319, 1348, 1413, 1440, 1462, 1478, 1514, 1560, 1591, 2834, 2931, 3004, 3044. ${ }^{1} \mathrm{H}-\mathrm{NMR}\left(\mathrm{CDCl}_{3}\right): 3.85$ (s, $3 \mathrm{H}, \mathrm{OMe}), 7.00-7.05\left(\mathrm{~m}, 2 \mathrm{H}, \mathrm{H}^{\prime}{ }^{\prime}\right.$ and $\left.\mathrm{H}^{\prime}\right), 7.18(\mathrm{dd}, 1 \mathrm{H}, J=7.9$ and $4.7 \mathrm{~Hz}, \mathrm{H} 5), 7.54(\mathrm{~s}$, $1 \mathrm{H}, \mathrm{H} 2), 7.53-7.58\left(\mathrm{~m}, 2 \mathrm{H}, \mathrm{H} 2^{\prime}\right.$ and $\left.\mathrm{H6}^{\prime}\right), 7.77(\mathrm{dd}, 1 \mathrm{H}, J=7.9$ and $1.6 \mathrm{~Hz}, \mathrm{H} 4), 8.36(\mathrm{dd}$, $1 \mathrm{H}, J=4.7$ and $1.5 \mathrm{~Hz}, \mathrm{H} 6) .{ }^{13} \mathrm{C}-\mathrm{NMR}\left(\mathrm{CDCl}_{3}\right): 55.7\left(\mathrm{CH}_{3}, \mathrm{OMe}\right), 55.7(\mathrm{C}, \mathrm{C} 3, \mathrm{C}-\mathrm{I}), 114.7$ $\left(2 \mathrm{CH}, \mathrm{C}^{\prime}\right.$ and $\left.\mathrm{C}^{\prime}\right), 117.4(\mathrm{CH}, \mathrm{C} 5), 123.7(\mathrm{C}, \mathrm{Cb}), 125.8\left(2 \mathrm{CH}, \mathrm{C}^{\prime}\right.$ and $\left.\mathrm{C}^{\prime}\right), 129.5(\mathrm{CH}, \mathrm{C} 4)$, $130.8\left(\mathrm{C}, \mathrm{Cl}^{\prime}\right), 132.3(\mathrm{CH}, \mathrm{C} 2), 144.7(\mathrm{CH}, \mathrm{C} 6), 147.3(\mathrm{C}, \mathrm{Ca}), 158.6\left(\mathrm{C}, \mathrm{C4}^{\prime}\right)$. Anal. Calc. for $\mathrm{C}_{14} \mathrm{H}_{11} \mathrm{IN}_{2} \mathrm{O}$ (350.16): C 48.02, H 3.17, N 8.00. Found: C 48.08, H 3.47, N 7.76. 


\subsubsection{1-(4-Chlorophenyl)-3-iodo-7-azaindole (4c)}

The general procedure 8 from 1-(4-chlorophenyl)-7-azaindole (1c;0.23 g) afforded (eluent: heptane- $\mathrm{Et}_{2} \mathrm{O} 80: 20$ ) the title product in $40 \%$ yield as a white solid. $\mathrm{Mp} 110{ }^{\circ} \mathrm{C}$, IR: 673, 705, 747, 762, 792, 827, 924, 978, 1014, 1039, 1092, 1110, 1144, 1191, 1221, 1266, 1278, 1313, 1338, 1351, 1406, 1490, 1509, 1560, 1590, 1722, 1889, 2418, 2628, 2855, 2924, 3014, 3125, 3096, 3044. ${ }^{1} \mathrm{H}-\mathrm{NMR}\left(\mathrm{CDCl}_{3}\right): 7.21(\mathrm{dd}, 1 \mathrm{H}, J=7.9$ and $4.7 \mathrm{~Hz}, \mathrm{H} 5), 7.45-7.50(\mathrm{~m}, 2 \mathrm{H}, \mathrm{Ph})$, $7.57(\mathrm{~s}, 1 \mathrm{H}, \mathrm{H} 2), 7.65-7.69(\mathrm{~m}, 2 \mathrm{H}, \mathrm{Ph}), 7.77(\mathrm{dd}, 1 \mathrm{H}, J=7.9$ and $1.6 \mathrm{~Hz}, \mathrm{H} 4), 8.37(\mathrm{dd}, 1 \mathrm{H}$, $J=4.7$ and $1.5 \mathrm{~Hz}, \mathrm{H} 6) .{ }^{13} \mathrm{C}-\mathrm{NMR}\left(\mathrm{CDCl}_{3}\right) .55 .2(\mathrm{C}, \mathrm{C} 3, \mathrm{C}-\mathrm{I}), 117.9(\mathrm{CH}, \mathrm{C} 5), 124.1(\mathrm{C}, \mathrm{Cb})$, $125.0(2 \mathrm{CH}, \mathrm{Ph}), 129.6(2 \mathrm{CH}, \mathrm{Ph}), 129.8(\mathrm{CH}, \mathrm{C} 4), 131.4(\mathrm{CH}, \mathrm{C} 2), 132.4\left(\mathrm{C}, \mathrm{Cl}^{\prime}\right.$ or $\left.\mathrm{C}^{\prime}\right), 136.3$ (C, $\mathrm{C1}^{\prime}$ or $\left.\mathrm{C4}^{\prime}\right), 144.9(\mathrm{CH}, \mathrm{C} 6), 147.1$ (C, Ca). Crystal data for 4c. $\mathrm{C}_{13} \mathrm{H}_{8} \mathrm{ClIN}_{2}, M=354.56$, $T=150(2) \mathrm{K}$, monoclinic, $C, a=4.0519(5), b=25.673(3), c=11.5697(15) \AA, \beta=93.736(4)^{\circ}$, $V=1201.0(3) \AA^{3}, Z=4, d=1.961 \mathrm{~g} \mathrm{~cm}^{-3}, \mu=2.865 \mathrm{~mm}^{-1}$. A final refinement on $F^{2}$ with 2645 unique intensities and 154 parameters converged at $\omega R\left(F^{2}\right)=0.0591(R(F)=0.0237)$ for 2622 observed reflections with $I>2 \sigma(I)$. CCDC 2109698.

\subsubsection{1-(4-Fluorophenyl)-3-iodo-7-azaindole (4d)}

The general procedure 7 from 1-(4-fluorophenyl)-7-azaindole $(\mathbf{1 d} ; 0.21 \mathrm{~g})$ afforded (eluent: heptane-EtOAc 90:10) the title product in $52 \%$ yield as a white solid. Mp $98{ }^{\circ} \mathrm{C}$, IR: 702, 764, 794, 818, 834, 925, 980, 1111, 1158, 1215, 1269, 1319, 1413, 1479, 1514, 1561, 1592, 2923. ${ }^{1} \mathrm{H}-\mathrm{NMR}\left(\mathrm{CDCl}_{3}\right)$ : 7.18-7.25 (m, 3H, $\mathrm{H} 5$ and Ph), 7.63-7.70 (m, 2H, Ph), $7.57(\mathrm{~s}, 1 \mathrm{H}$, $\mathrm{H} 2), 7.80(\mathrm{dd}, 1 \mathrm{H}, J=7.9$ and $1.6 \mathrm{~Hz}, \mathrm{H} 4), 8.38(\mathrm{dd}, 1 \mathrm{H}, J=4.7$ and $1.5 \mathrm{~Hz}, \mathrm{H} 6) .{ }^{13} \mathrm{C}-\mathrm{NMR}$ $\left(\mathrm{CDCl}_{3}\right): 56.6(\mathrm{C}, \mathrm{C} 3, \mathrm{C}-\mathrm{I}), 116.5\left(\mathrm{~d}, 2 \mathrm{CH}, \mathrm{J}=23 \mathrm{~Hz}, \mathrm{C}^{\prime}\right.$ and $\left.\mathrm{C}^{\prime}\right), 117.8(\mathrm{CH}, \mathrm{C} 5), 124.0(\mathrm{C}$, $\mathrm{Cb}), 126.0\left(\mathrm{~d}, 2 \mathrm{CH}, J=8.4 \mathrm{~Hz}, \mathrm{C}^{\prime}\right.$ and $\left.\mathrm{C6}^{\prime}\right), 129.8(\mathrm{CH}, \mathrm{C} 4), 131.9(\mathrm{CH}, \mathrm{C} 2), 133.9(\mathrm{~d}, \mathrm{C}$, $\left.J=3.0 \mathrm{~Hz}, \mathrm{C1}^{\prime}\right), 145.0(\mathrm{CH}, \mathrm{C} 6), 147.3$ (C, Ca), 161.4 (d, C, J = 247 Hz, C4', C-F). Anal. Calc. for $\mathrm{C}_{13} \mathrm{H}_{8} \mathrm{FIN}_{2}$ (338.12): C 46.18, H 2.38, N 8.29. Found: C 46.32, H 2.12, N 8.11.

\subsubsection{3-Iodo-1-(4-(trifluoromethyl)phenyl)-7-azaindole (4e)}

The general procedure 7 and 8 from 1-(4-(trifluoromethyl)phenyl)-7-azaindole (1e; $0.26 \mathrm{~g}$ ) afforded (eluent: heptane-EtOAc 90:10) the title product in 33 and $45 \%$ yield, respectively, as a white solid. Mp $78-80{ }^{\circ} \mathrm{C}$, IR: $454,762,794,841,924,982,1016,1068,1111$, 1124, 1168, 1224, 1269, 1319, 1411, 1475, 1527, 1567, 1596, 1617, 1729, 2856, 2925, 2956, 3052, 3133. ${ }^{1} \mathrm{H}-\mathrm{NMR}\left(\mathrm{CDCl}_{3}\right): 7.23(\mathrm{dd}, 1 \mathrm{H}, J=7.9$ and $4.7 \mathrm{~Hz}, \mathrm{H} 5), 7.63(\mathrm{~s}, 1 \mathrm{H}, \mathrm{H} 2), 7.76(\mathrm{~d}, 2 \mathrm{H}$, $J=8.5 \mathrm{~Hz}, \mathrm{Ph}), 7.78(\mathrm{dd}, 1 \mathrm{H}, J=7.9$ and $1.6 \mathrm{~Hz}, \mathrm{H} 4), 7.91(\mathrm{~d}, 2 \mathrm{H}, J=8.4 \mathrm{~Hz}, \mathrm{Ph}), 8.39(\mathrm{dd}$, $1 \mathrm{H}, J=4.7$ and $1.5 \mathrm{~Hz}, \mathrm{H} 6) .{ }^{13} \mathrm{C}-\mathrm{NMR}\left(\mathrm{CDCl}_{3}\right): 58.3(\mathrm{C}, \mathrm{C} 3, \mathrm{C}-\mathrm{I}), 118.2(\mathrm{CH}, \mathrm{C} 5), 123.4(2 \mathrm{CH}$, $\mathrm{C} 2^{\prime}$ and $\left.\mathrm{C}^{\prime}\right), 124.0\left(\mathrm{~d}, \mathrm{C}, J=272 \mathrm{~Hz}, \mathrm{CF}_{3}\right), 124.4(\mathrm{C}, \mathrm{Cb}), 126.7\left(\mathrm{q}, 2 \mathrm{CH}, J=3.8 \mathrm{~Hz}, \mathrm{C}^{\prime}\right.$ and $\left.\mathrm{C}^{\prime}\right), 128.4\left(\mathrm{~d}, \mathrm{C}, J=32.8 \mathrm{~Hz}, \mathrm{C} 4^{\prime}\right), 130.0(\mathrm{CH}, \mathrm{C} 4), 131.0(\mathrm{CH}, \mathrm{C} 2), 140.6\left(\mathrm{C}, \mathrm{Cl}^{\prime}\right), 145.0(\mathrm{CH}$, C6), $147.1(\mathrm{C}, \mathrm{Ca})$. Crystal data for 4 e. $\mathrm{C}_{14} \mathrm{H}_{8} \mathrm{~F}_{3} \mathrm{IN} 2, M=388.12, T=150(2) \mathrm{K}$, monoclinic, $P$ $21 / n, a=19.7915(9), b=7.5240(4), c=19.8815(11) \AA, \beta=117.242(2)^{\circ}, V=2632.2(2) \AA^{3}, Z=8$, $d=1.959 \mathrm{~g} \mathrm{~cm}^{-3}, \mu=2.459 \mathrm{~mm}^{-1}$. A final refinement on $F^{2}$ with 6006 unique intensities and 357 parameters converged at $\omega R\left(F^{2}\right)=0.0809(R(F)=0.0391)$ for 4927 observed reflections with $I>2 \sigma(I)$. CCDC 2109699.

\subsubsection{3-Iodo-1-(3,5-dimethylphenyl)-7-azaindole (4f)}

The general procedure 7 from 1-(3,5-dimethylphenyl)-7-azaindole (1f; $0.22 \mathrm{~g})$ afforded (eluent: hexane- $\mathrm{CHCl}_{3} 60: 40$ ) the title product in $62 \%$ yield as a white solid. Mp $80{ }^{\circ} \mathrm{C}$, IR: $664,689,762,789,824,845,891,934,965,998,1037,1056,1080,1109,1137,1188,1210,1258$, 1281, 1314, 1322, 1340, 1361, 1378, 1404, 1433, 1465, 1491, 1508, 1562, 1590, 1611, 1727, 1918, 2853, 2919, 2952, 3010, 3042, 3123, 3629. ${ }^{1} \mathrm{H}-\mathrm{NMR}\left(\mathrm{CDCl}_{3}\right): 2.40(\mathrm{~d}, 6 \mathrm{H}, \mathrm{J}=0.5 \mathrm{~Hz}, \mathrm{Me}), 7.01$ (br s, $\left.1 \mathrm{H}, \mathrm{H} 4^{\prime}\right), 7.20(\mathrm{dd}, 1 \mathrm{H}, J=7.9$ and $4.7 \mathrm{~Hz}, \mathrm{H} 5), 7.29\left(\mathrm{br} \mathrm{s}, 2 \mathrm{H}, \mathrm{H} 2^{\prime}\right.$ and $\left.\mathrm{H}^{\prime}\right), 7.58(\mathrm{~s}, 1 \mathrm{H}$, $\mathrm{H} 2), 7.78(\mathrm{dd}, 1 \mathrm{H}, J=7.9$ and $1.6 \mathrm{~Hz}, \mathrm{H} 4), 8.38(\mathrm{dd}, 1 \mathrm{H}, J=4.7$ and $1.5 \mathrm{~Hz}, \mathrm{H} 6) .{ }^{13} \mathrm{C}-\mathrm{NMR}$ $\left(\mathrm{CDCl}_{3}\right)$ : $21.5\left(2 \mathrm{CH}_{3}, \mathrm{Me}\right), 56.0(\mathrm{C}, \mathrm{C} 3, \mathrm{C}-\mathrm{I}), 117.5(\mathrm{CH}, \mathrm{C} 5), 122.3\left(2 \mathrm{CH}, \mathrm{C}^{\prime}\right.$ and $\left.\mathrm{C}^{\prime}\right), 124.0$ $(\mathrm{C}, \mathrm{Cb}), 128.9\left(\mathrm{CH}, \mathrm{C}^{\prime}\right), 129.6(\mathrm{CH}, \mathrm{C} 4), 132.4(\mathrm{CH}, \mathrm{C} 2), 137.7\left(\mathrm{C}, \mathrm{Cl}^{\prime}\right), 139.3\left(2 \mathrm{C}, \mathrm{C}^{\prime}\right.$ and $\left.\mathrm{C}^{\prime}\right), 144.8$ (CH, C6), 147.4 (C, Ca). Anal. Calc. for $\mathrm{C}_{15} \mathrm{H}_{13} \mathrm{IN}_{2}$ (348.19): C 51.74, H 3.76, N 8.05. Found: C 51.43, H 3.44, N 7.88. 
3.6.9. 1-(5-Iodo-2-thienyl)-7-azaindole (3g)

The general procedure 7 from 1-(2-thienyl)-7-azaindole (1g; $0.20 \mathrm{~g}$ ) afforded (eluent: hexane- $\mathrm{CHCl}_{3} 70: 30$ ) the title product in $35 \%$ yield as a white solid. Its analyses were found identical to those reported in Section 3.4.7.

\subsubsection{3-Iodo-1-(3-pyridyl)-7-azaindole (4h)}

The general procedure 7 (but at $40{ }^{\circ} \mathrm{C}$ ) and 8 (but for $10 \mathrm{~h}$ ) from 1-(3-pyridyl)-7azaindole (1h; $0.20 \mathrm{~g}$ ) afforded (eluent: heptane-EtOAc 80:20) the title product in $36 \%$ and $45 \%$ yield, respectively, as a yellow solid. Mp $114{ }^{\circ} \mathrm{C}$, IR: 703, 739, 763, 796, 924, 978, 1023, $1045,1110,1145,1186,1208,1227,1271,1311,1320,1353,1406,1431,1484,1510,1560,1583$, $1718,1899,2139,2853,2922,3043,3356,3650 .{ }^{1} \mathrm{H}-\mathrm{NMR}\left(\mathrm{CDCl}_{3}\right): 7.23(\mathrm{dd}, 1 \mathrm{H}, J=7.9$ and $4.7 \mathrm{~Hz}, \mathrm{H} 5), 7.45\left(\mathrm{dd}, 1 \mathrm{H}, J=8.2\right.$ and $\left.4.8 \mathrm{~Hz}, \mathrm{H} 5^{\prime}\right), 7.63(\mathrm{~s}, 1 \mathrm{H}, \mathrm{H} 2), 7.78(\mathrm{dd}, 1 \mathrm{H}, J=7.9$ and $1.5 \mathrm{~Hz}, \mathrm{H} 4), 8.20\left(\mathrm{ddd}, 1 \mathrm{H}, J=8.2,2.5\right.$ and $\left.1.5 \mathrm{~Hz}, \mathrm{H} 4^{\prime}\right), 8.37(\mathrm{dd}, 1 \mathrm{H}, J=4.7$ and $1.5 \mathrm{~Hz}$, H6), $8.59\left(\mathrm{dd}, 1 \mathrm{H}, J=4.7\right.$ and $\left.1.1 \mathrm{~Hz}, \mathrm{H}^{\prime}\right), 8.97\left(\mathrm{~d}, 1 \mathrm{H}, J=2.3 \mathrm{~Hz}, \mathrm{H2}{ }^{\prime}\right) .{ }^{13} \mathrm{C}-\mathrm{NMR}\left(\mathrm{CDCl}_{3}\right)$ : $58.0(\mathrm{C}, \mathrm{C} 3, \mathrm{C}-\mathrm{I}), 118.1(\mathrm{CH}, \mathrm{C} 5), 123.9\left(\mathrm{CH}, \mathrm{C5}^{\prime}\right), 124.2(\mathrm{C}, \mathrm{Cb}), 130.0(\mathrm{CH}, \mathrm{C} 4), 130.8(\mathrm{CH}$, C2), $131.1\left(\mathrm{CH}, \mathrm{C4}^{\prime}\right), 134.5\left(\mathrm{C}, \mathrm{C}^{\prime}\right), 144.6(\mathrm{CH}, \mathrm{C} 6), 145.1\left(\mathrm{CH}, \mathrm{C}^{\prime}\right.$ or $\left.\mathrm{C}^{\prime}\right), 147.1(\mathrm{C}, \mathrm{Ca})$, 147.7 (CH, C2' or $\left.\mathrm{C}^{\prime}\right)$. Crystal data for $4 \mathrm{~h} . \mathrm{C}_{12} \mathrm{H}_{8} \mathrm{IN}_{3}, M=321.11, T=150(2) \mathrm{K}$, triclinic, $P$ $-1, a=3.9819(2), b=8.8450(5), c=16.4714(9) \AA, \alpha=74.841(2), \beta=83.779(2), \gamma=78.265(2)^{\circ}$, $V=547.30(5) \AA^{3}, Z=2, d=1.949 \mathrm{~g} \mathrm{~cm}^{-3}, \mu=2.899 \mathrm{~mm}^{-1}$. A final refinement on $F^{2}$ with 2497 unique intensities and 145 parameters converged at $\omega R\left(F^{2}\right)=0.0453(R(F)=0.0195)$ for 2375 observed reflections with $I>2 \sigma(I)$. CCDC 2109700.

\subsubsection{3-Iodo-1-(2-pyridyl)-7-azaindole (4i)}

The general procedure 7 and 8 from 1-(2-pyridyl)-7-azaindole (1i; $0.20 \mathrm{~g}$ ) afforded (eluent: $\mathrm{CHCl}_{3}$-hexane $60: 40$ ) the title product in $17 \%$ and $51 \%$ yield, respectively, as a yellow solid. Mp $108^{\circ} \mathrm{C}$, IR: 739, 764, 775, 823, 884, 929, 962, 983, 1000, 1050, 1079, 1096, 1109, 1133, 1151, 1188, 1219, 1262, 1302, 1352, 1362, 1404, 1436, 1466, 1478, 1511, 1562, 1587, 1611, 1724, 1860, 1919, 2626, 2850, 2920, 2953, 3011, 3058, 3107, 3145, 3628, 3735. ${ }^{1} \mathrm{H}-\mathrm{NMR}\left(\mathrm{CDCl}_{3}\right): 7.15\left(\mathrm{ddd}, 1 \mathrm{H}, J=7.3,4.9\right.$ and $\left.0.8 \mathrm{~Hz}, \mathrm{H}^{\prime}\right), 7.22(\mathrm{dd}, 1 \mathrm{H}, J=7.9$ and $4.8 \mathrm{~Hz}, \mathrm{H} 5), 7.75(\mathrm{dd}, 1 \mathrm{H}, J=7.9$ and $1.6 \mathrm{~Hz}, \mathrm{H} 4), 7.84(\mathrm{ddd}, 1 \mathrm{H}, J=8.4,7.4$ and $1.9 \mathrm{~Hz}$, $\left.\mathrm{H} 4^{\prime}\right), 8.39(\mathrm{dd}, 1 \mathrm{H}, J=4.7$ and $1.4 \mathrm{~Hz}, \mathrm{H} 6), 8.45\left(\mathrm{dd}, 1 \mathrm{H}, J=4.8\right.$ and $\left.1.1 \mathrm{~Hz}, \mathrm{H} 6^{\prime}\right), 8.52$ $(\mathrm{s}, 1 \mathrm{H}, \mathrm{H} 2), 8.84\left(\mathrm{~d}, 1 \mathrm{H}, J=8.4 \mathrm{~Hz}, \mathrm{H} 3{ }^{\prime}\right) .{ }^{13} \mathrm{C}-\mathrm{NMR}\left(\mathrm{CDCl}_{3}\right): 58.9(\mathrm{C}, \mathrm{C} 3, \mathrm{C}-\mathrm{I}), 115.6(\mathrm{CH}$, $\left.\mathrm{C}^{\prime}\right), 118.0(\mathrm{CH}, \mathrm{C} 5), 120.9\left(\mathrm{CH}, \mathrm{C5}^{\prime}\right), 125.6(\mathrm{C}, \mathrm{Cb}), 129.7(\mathrm{CH}, \mathrm{C} 4), 130.8(\mathrm{CH}, \mathrm{C} 2), 138.4$ $\left(\mathrm{CH}, \mathrm{C4}^{\prime}\right), 144.3(\mathrm{CH}, \mathrm{C} 6), 147.0(\mathrm{C}, \mathrm{Ca}), 148.3\left(\mathrm{CH}, \mathrm{C6}^{\prime}\right), 150.1\left(\mathrm{C}, \mathrm{C}^{\prime}\right)$. Crystal data for 4i. $\mathrm{C}_{12} \mathrm{H}_{8} \mathrm{IN}_{3}, M=321.11, T=150(2) \mathrm{K}$, monoclinic, $P 2{ }_{1} / n, a=7.7719(12), b=8.1656(12)$, $c=17.328(2) \AA, \beta=90.723(5)^{\circ}, V=1099.6(3) \AA^{3}, Z=4, d=1.940 \mathrm{~g} \mathrm{~cm}^{-3}, \mu=2.885 \mathrm{~mm}^{-1}$. A final refinement on $F^{2}$ with 2518 unique intensities and 145 parameters converged at $\omega R\left(F^{2}\right)=0.0647(R(F)=0.0285)$ for 2275 observed reflections with $I>2 \sigma(I)$. CCDC 2109701.

\subsection{N-Arylation of Azoles by Using 1-Arylated 3-Iodo-7-azaindoles}

3.7.1. 3-(1-Indolyl)-1-(4-(trifluoromethyl)phenyl)-7-azaindole (5e)

A mixture of 3-iodo-1-(4-(trifluoromethyl)phenyl)-7-azaindole (4e; $0.39 \mathrm{~g}, 1.0 \mathrm{mmol}$ ), indole $(0.12 \mathrm{~g}, 1.0 \mathrm{mmol}), \mathrm{Cu}_{2} \mathrm{O}(7 \mathrm{mg}, 50 \mu \mathrm{mol})$ and $\mathrm{Cs}_{2} \mathrm{CO}_{3}(0.65 \mathrm{~g}, 2.0 \mathrm{mmol})$ in DMSO $(1 \mathrm{~mL})$ was heated at $110^{\circ} \mathrm{C}$ under argon for $24 \mathrm{~h}$. The reaction mixture was cooled to rt. The residue was taken with EtOAc $(20 \mathrm{~mL})$ and filtrated over celite. Removal of the solvent under reduced pressure and purification of the crude over silica gel (eluent: heptane-EtOAc 80:20) afforded the title product in $30 \%$ yield as a colorless oil. IR: 424, 447, 561, 593, 621, $655,664,712,726,746,758,766,801,842,881,904,934,949,962,1016,1066,1105,1129,1162$, $1188,1210,1240,1268,1322,1349,1365,1389,1420,1455,1472,1482,1521,1565,1582,1595$, 1614, 1724, 2852, 2923, 2955, 3049. ${ }^{1} \mathrm{H}-\mathrm{NMR}\left(\mathrm{CDCl}_{3}\right): 6.57\left(\mathrm{dd}, 1 \mathrm{H}, J=3.4\right.$ and $\left.0.8 \mathrm{~Hz}, \mathrm{H}^{\prime}\right)$, $6.75(\mathrm{~s}, 1 \mathrm{H}, \mathrm{H} 2), 6.92\left(\mathrm{~d}, 1 \mathrm{H}, J=3.4 \mathrm{~Hz}, \mathrm{H} 2^{\prime}\right), 7.19(\mathrm{dd}, 1 \mathrm{H}, J=5.6$ and $1.4 \mathrm{~Hz}), 7.22(\mathrm{dd}$, $1 \mathrm{H}, J=5.9$ and $1.4 \mathrm{~Hz}), 7.21(\mathrm{dd}, 1 \mathrm{H}, J=7.8$ and $4.8 \mathrm{~Hz}, \mathrm{H} 5), 7.35(\mathrm{~d}, 2 \mathrm{H}, J=8.3 \mathrm{~Hz}, \mathrm{Ph}$ ), $7.41(\mathrm{~d}, 1 \mathrm{H}, J=8.0 \mathrm{~Hz}), 7.56(\mathrm{~d}, 2 \mathrm{H}, J=8.4 \mathrm{~Hz}, \mathrm{Ph}), 7.62-7.65(\mathrm{~m}, 1 \mathrm{H}), 8.04(\mathrm{dd}, 1 \mathrm{H}, J=7.8$ and $1.6 \mathrm{~Hz}, \mathrm{H} 4), 8.41(\mathrm{dd}, 1 \mathrm{H}, J=4.8$ and $1.6 \mathrm{~Hz}, \mathrm{H} 6) .{ }^{13} \mathrm{C}-\mathrm{NMR}\left(\mathrm{CDCl}_{3}\right): 98.1(\mathrm{CH}), 102.8$ 
(C), $105.3(\mathrm{CH}), 110.7(\mathrm{CH}), 118.3(\mathrm{CH}, \mathrm{C} 5), 120.1(\mathrm{C}), 121.3(\mathrm{CH}), 121.4(\mathrm{CH}), 123.4(\mathrm{CH})$, $126.5\left(\mathrm{q}, 2 \mathrm{CH}, \mathrm{J}=3.5 \mathrm{~Hz}, \mathrm{C}^{\prime \prime}\right.$ and C5"), $126.8(2 \mathrm{CH}, \mathrm{C2}$ " and C6"), $128.4(\mathrm{CH}, \mathrm{C} 4), 128.7$ (C), $129.2(\mathrm{CH}), 134.4(\mathrm{C}), 137.5(\mathrm{C}), 138.3(\mathrm{C}), 144.5(\mathrm{CH}, \mathrm{C} 6)$; C4" and $\mathrm{CF}_{3}$ not seen. Anal. Calc. for $\mathrm{C}_{22} \mathrm{H}_{14} \mathrm{~F}_{3} \mathrm{~N}_{3}$ (377.37): C 70.02, H 3.74, N 11.14. Found: C 70.15, H 3.69, N 11.15.

\subsubsection{General Procedure 9 Using Copper(I) Iodide with Ligand}

A mixture of the iodinated $(1.0 \mathrm{mmol})$ or diiodinated $(0.50 \mathrm{mmol}) 7$-azaindole, indole $(0.14 \mathrm{~g}, 1.2 \mathrm{mmol}), \mathrm{CuI}(9.5 \mathrm{mg}, 50 \mu \mathrm{mol}), \mathrm{DMEDA}(11 \mu \mathrm{L}, 0.10 \mathrm{mmol})$ and $\mathrm{K}_{3} \mathrm{PO}_{4}(0.42 \mathrm{~g}$, $2.0 \mathrm{mmol})$ in DMF $(1 \mathrm{~mL})$ was degassed and heated at reflux under argon (the reaction time is given in the product description). The reaction mixture was cooled to rt. The residue was taken with EtOAc $(20 \mathrm{~mL})$ and filtrated over celite. Removal of the solvent under reduced pressure and purification of the crude over silica gel (the eluent is given in the product description) gave the product.

\subsubsection{3-(1-Indolyl)-1-(2-pyridyl)-7-azaindole (5i)}

The general procedure 9 (reaction time: $24 \mathrm{~h}$ ) from 3-iodo-1-(2-pyridyl)-7-azaindole (4i; $0.32 \mathrm{~g}$ ) afforded (eluent: $\mathrm{CH}_{2} \mathrm{Cl}_{2}$-hexane $70: 30$ ) the title product in $50 \%$ yield as a white solid. Mp $136{ }^{\circ} \mathrm{C}$, IR (ATR): 739, 762, 774, 907, 968, 997, 1010, 1052, 1134, 1213, 1230, 1267, 1303, 1294, 1340, 1423, 1440, 1469, 1513, 1575, 1590, 1606, 3022, 3052, 3110, 3133. ${ }^{1} \mathrm{H}-\mathrm{NMR}$ $\left(\mathrm{CDCl}_{3}\right): 6.81(\mathrm{dd}, 1 \mathrm{H}, J=3.2$ and $0.9 \mathrm{~Hz}), 7.15-7.20(\mathrm{~m}, 2 \mathrm{H}), 7.25-7.33(\mathrm{~m}, 2 \mathrm{H}), 7.44(\mathrm{~d}, 1 \mathrm{H}$, $J=3.2 \mathrm{~Hz}), 7.51-7.54(\mathrm{~m}, 1 \mathrm{H}), 7.80-7.91(\mathrm{~m}, 3 \mathrm{H}), 8.52(\mathrm{ddd}, 2 \mathrm{H}, J=7.3,4.9$ and $1.7 \mathrm{~Hz}), 8.67$ $(\mathrm{s}, 1 \mathrm{H}), 9.07\left(\mathrm{~d}, 1 \mathrm{H}, \mathrm{J}=8.4 \mathrm{~Hz}, \mathrm{H3}{ }^{\prime \prime}\right) .{ }^{13} \mathrm{C}-\mathrm{NMR}\left(\mathrm{CDCl}_{3}\right): 103.4(\mathrm{CH}), 110.8(\mathrm{CH}), 116.0(\mathrm{CH}$, $\left.\mathrm{C3}^{\prime \prime}\right), 117.4(\mathrm{CH}, \mathrm{C} 5), 117.5(\mathrm{C}), 119.0(\mathrm{C}), 120.4(\mathrm{CH}), 120.4(\mathrm{CH}), 120.6(\mathrm{CH}), 121.1(\mathrm{CH})$, $122.4(\mathrm{CH}), 127.5(\mathrm{C}, \mathrm{Cb}), 128.8(\mathrm{CH}), 128.9(\mathrm{CH}), 137.0(\mathrm{C}), 138.3\left(\mathrm{CH}, \mathrm{C4}{ }^{\prime \prime}\right), 144.3(\mathrm{CH}$, C6), 145.9 (C, Ca), 148.2 (CH, C6"), 150.2 (C, C2"). Crystal data for 5 i. $\mathrm{C}_{20} \mathrm{H}_{14} \mathrm{~N}_{4}, M=310.35$, $T=150(2) \mathrm{K}$, triclinic, $P-1, a=7.0573(10), b=8.3875(11), c=13.563(2) \AA, \alpha=87.146(5)$, $\beta=75.381(5), \gamma=72.673(5)^{\circ}, V=741.31(19) \AA^{3}, Z=2, d=1.390 \mathrm{~g} \mathrm{~cm}^{-3}, \mu=0.086 \mathrm{~mm}^{-1}$. A final refinement on $F^{2}$ with 3361 unique intensities and 217 parameters converged at $\omega R\left(F^{2}\right)=0.0994(R(F)=0.0389)$ for 2635 observed reflections with $I>2 \sigma(I)$. CCDC 2109702.

\subsubsection{2-(1-Indolyl)-1-(5-(1-indolyl)-2-thienyl)-7-azaindole $\left(\mathbf{6 g}^{\prime}\right)$}

The general procedure 9 (reaction time: $24 \mathrm{~h}$ ) from 2-iodo-1-(5-iodo-2-thienyl)-1Hpyrrolo[2,3-b]pyridine $\left(\mathbf{3 g}^{\prime} ; 0.23 \mathrm{~g}\right.$ ) afforded (eluent: petroleum ether-EtOAc 80:20) the title product in $20 \%$ yield as a yellow oil. IR: 422, 659, 714, 737, 761, 801, 881, 902, 929, 965, 1012, $1043,1071,1106,1127,1207,1266,1303,1316,1336,1347,1387,1412,1450,1474,1504,1517$, $1568,1594,1713,2923,2960,3050 .{ }^{1} \mathrm{H}-\mathrm{NMR}\left(\mathrm{CDCl}_{3}\right): 6.61(\mathrm{dd}, 1 \mathrm{H}, J=3.3$ and $0.9 \mathrm{~Hz}), 6.69$ $(\mathrm{dd}, 1 \mathrm{H}, J=3.3$ and $0.9 \mathrm{~Hz}), 6.77(\mathrm{~s}, 1 \mathrm{H}), 6.77(\mathrm{~d}, 1 \mathrm{H}, J=3.6 \mathrm{~Hz}), 6.80(\mathrm{~d}, 1 \mathrm{H}, J=4.0 \mathrm{~Hz})$, 7.15-7.28 (m, 6H), $7.29(\mathrm{dd}, 1 \mathrm{H}, J=7.9$ and $4.9 \mathrm{~Hz}), 7.39(\mathrm{t}, 1 \mathrm{H}, J=8.2 \mathrm{~Hz}), 7.62(\mathrm{dd}, 1 \mathrm{H}$, $J=6.5$ and $1.2 \mathrm{~Hz}), 7.68(\mathrm{dd}, 1 \mathrm{H}, J=6.4$ and $2.0 \mathrm{~Hz}), 8.04(\mathrm{dd}, 1 \mathrm{H}, J=7.9$ and $1.6 \mathrm{~Hz}), 8.51$ $(\mathrm{dd}, 1 \mathrm{H}, J=4.8$ and $1.6 \mathrm{~Hz}) .{ }^{13} \mathrm{C}-\mathrm{NMR}\left(\mathrm{CDCl}_{3}\right)$ : $98.7(\mathrm{CH}), 104.5(\mathrm{CH}), 105.2(\mathrm{CH}), 110.7$ $(\mathrm{CH}), 110.7(\mathrm{CH}), 118.4(\mathrm{CH}), 118.9(\mathrm{CH}), 120.0(\mathrm{C}), 121.1(\mathrm{CH}), 121.1(\mathrm{CH}), 121.2(\mathrm{CH})$, $121.3(\mathrm{CH}), 123.0(\mathrm{CH}), 123.2(\mathrm{CH}), 123.4(\mathrm{CH}), 128.7(\mathrm{C}), 128.8(\mathrm{CH}), 129.1(\mathrm{CH}), 129.1(\mathrm{C})$, $129.3(\mathrm{CH}), 130.7(\mathrm{C}), 135.2(\mathrm{C}), 137.0(\mathrm{C}), 138.0(\mathrm{C}), 139.8(\mathrm{C}), 144.8(\mathrm{CH}, \mathrm{C} 6), 147.6$ (C, Ca). Anal. Calc. for $\mathrm{C}_{27} \mathrm{H}_{18} \mathrm{~N}_{4} \mathrm{~S}$ (430.53): C 75.33, H 4.21, N 13.01. Found: C 75.11, H 4.46, N 12.65.

\subsection{Evaluation of the Biological Properties}

The antibacterial, antifungal and antioxidant activity was determined as described previously [77].

\section{Conclusions}

Our goal in the present paper was to rationalize the conversion of 1-aryl-7-azaindoles into either the corresponding 2-iodo derivatives (by deprotometalation-iodolysis) or the corresponding 3-iodo derivatives (by direct iodination). This could be achieved by calculat- 
ing either the $\mathrm{p} K_{\mathrm{a}}$ values or the HOMO orbital coefficients, respectively. The atomic charges also allowed the regioselectivity of these reactions to be predicted. Thus, the obtained iodides were converted into derivatives with promising biological properties.

Supplementary Materials: The following data are available online. The NMR data of the compounds

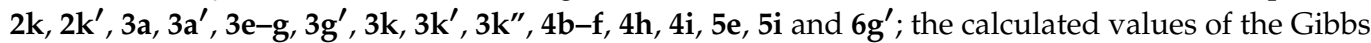
energies $\Delta G_{\text {acid }}\left[\mathrm{kJ} \cdot \mathrm{mol}^{-1}\right]$ for deprotonation, the cartesian coordinates of molecular geometry for the most stable rotamer form optimized at the B3LYP/6-31G(d) level of theory in the .xyz format.

Author Contributions: M.Y.A.M. synthesized all compounds presented in this article and analyzed most of them; G.B.-A. supervised; M.H. and Z.F. performed the bioassays. Y.S.H., O.A.I. and V.E.M. performed the computations. T.R. and V.D. collected all X-ray diffraction data and solved the structures. F.M. wrote the paper with the help of Z.F., Y.S.H., T.R. and V.D. All authors have read and agreed to the published version of the manuscript.

Funding: This research received no external funding.

Institutional Review Board Statement: Not applicable.

Informed Consent Statement: Not applicable.

Data Availability Statement: All data are included in this paper.

Acknowledgments: We thank the Centre National de la Recherche Scientifique (CNRS) and the Université de Rennes 1. We are grateful to the Fonds Européen de Développement Régional (FEDER; D8 VENTURE Bruker AXS diffractometer) and to Thermo Fischer for the generous gift of 2,2,6,6tetramethylpiperidine. We thank William Erb for his thorough rereading of the article, and Madani Hedidi and Frédéric Lassagne for their help in the analysis of the products. Z.F. thanks Taha Habdo and Hanine El Ghech for their helpful cooperation.

Conflicts of Interest: The authors declare no conflict of interest.

Sample Availability: Samples of the compounds $\mathbf{1 c}, \mathbf{1 e}, \mathbf{1 h}, \mathbf{1} \mathbf{j}, \mathbf{2 k}$ and $\mathbf{5 i}$ are available from the authors. All iodides should be prepared just before use due to moderate stability.

\section{References}

1. Prokopov, A.A.; Yakhontov, L.N. Chemistry of the azaindoles (review). Pharm. Chem. J. 1994, 28, 471-506. [CrossRef]

2. Mérour, J.-Y.; Joseph, B. Synthesis and reactivity of 7-azaindoles (1H-pyrrolo[2,3-b]pyridines). Curr. Org. Chem. 2001, 5, 471-506. [CrossRef]

3. Song, J.J.; Reeves, J.T.; Gallou, F.; Tan, Z.; Yee, N.K.; Senanayake, C.H. Organometallic methods for the synthesis and functionalization of azaindoles. Chem. Soc. Rev. 2007, 36, 1120-1132. [CrossRef] [PubMed]

4. Popowycz, F.; Routier, S.; Joseph, B.; Mérour, J.-Y. Synthesis and reactivity of 7-azaindole (1H-pyrrolo[2,3-b]pyridine). Tetrahedron 2007, 63, 1031-1064. [CrossRef]

5. Mérour, J.-Y.; Routier, S.; Suzenet, F.; Joseph, B. Recent advances in the synthesis and properties of 4-, 5-, 6- or 7-azaindoles. Tetrahedron 2013, 69, 4767-4834. [CrossRef]

6. Mérour, J.-Y.; Buron, F.; Plé, K.; Bonnet, P.; Routier, S. The azaindole framework in the design of kinase inhibitors. Molecules 2014, 19, 19935-19979. [CrossRef]

7. Santos, A.S.; Mortinho, A.C.; Marques, M.M.B. Metal-catalyzed cross-coupling reactions on azaindole synthesis and functionalization. Molecules 2018, 23, 2673. [CrossRef]

8. Kannaboina, P.; Mondal, K.; Laha, J.K.; Das, P. Recent advances in the global ring functionalization of 7-azaindoles. Chem. Commun. 2020, 56, 11749-11762. [CrossRef] [PubMed]

9. Echalier, A.; Bettayeb, K.; Ferandin, Y.; Lozach, O.; Clelment, M.; Valette, A.; Liger, F.; Marquet, B.; Morris, J.C.; Endicott, J.A.; et al. Meriolins (3-(pyrimidin-4-yl)-7-azaindoles): Synthesis, kinase inhibitory activity, cellular effects, and structure of a CDK2/cyclin A/meriolin complex. J. Med. Chem. 2008, 51, 737-751. [CrossRef]

10. Jarry, M.; Lecointre, C.; Malleval, C.; Desrues, L.; Schouft, M.-T.; Lejoncour, V.; Liger, F.; Lyvinec, G.; Joseph, B.; Loaec, N.; et al. Impact of meriolins, a new class of cyclin-dependent kinase inhibitors, on malignant glioma proliferation and neo-angiogenesis. Neuro-Oncol. 2014, 16, 1484-1498. [CrossRef]

11. Hardwicke, M.A.; Oleykowski, C.A.; Plant, R.; Wang, J.; Liao, Q.; Moss, K.; Newlander, K.; Adams, J.L.; Dhanak, D.; Yang, J.; et al. GSK1070916, a potent Aurora B/C kinase inhibitor with broad antitumor activity in tissue culture cells and human tumor xenograft models. Mol. Cancer Ther. 2009, 8, 1808-1817. [CrossRef]

12. Zhao, S.-B.; Wang, S. Luminescence and reactivity of 7-azaindole derivatives and complexes. Chem. Soc. Rev. 2010, 39, 3142-3156. [CrossRef] 
13. Li, S.-S.; Wang, C.-Q.; Lin, H.; Zhang, X.-M.; Dong, L. Rhodium(III)-catalyzed oxidative annulation of 7-azaindoles and alkynes via double C-H activation. Org. Lett. 2015, 17, 3018-3021. [CrossRef]

14. Li, S.-S.; Liu, C.-F.; Xia, Y.-Q.; Li, W.-H.; Zhang, G.-T.; Zhang, X.-M.; Dong, L. A unique annulation of 7-azaindoles with alkenyl esters to produce $\pi$-conjugated 7-azaindole derivatives. Org. Biomol. Chem. 2016, 14, 5214-5218. [CrossRef] [PubMed]

15. Liu, B.; Li, R.; Zhan, W.; Wang, X.; Ge, Z.; Li, R. Rh(iii)-catalyzed c-h oxidative ortho-olefination of arenes using 7-azaindole as a directing group and utilization in the construction of new tetracyclic heterocycles containing a 7-azaindole skeleton. RSC Adv. 2016, 6, 48205-48211. [CrossRef]

16. Jeon, M.; Park, J.; Dey, P.; Oh, Y.; Oh, H.; Han, S.; Um, S.H.; Kim, H.S.; Mishra, N.K.; Kim, I.S. Site-selective rhodium(iii)-catalyzed c-h amination of 7-azaindoles with anthranils: Synthesis and anticancer evaluation. Adv. Synth. Catal. 2017, 359, 3471-3478. [CrossRef]

17. Zhang, G.-T.; Zhang, J.; Xu, Y.-J.; Dong, L. Metal-free [3+2] tandem cyclization synthesis of unique 11 h-pyrido[3' $\left.2^{\prime} 2^{\prime}: 4,5\right]$ pyrrolo [3,2-b] indolizine from 7-azaindoles and pyridotriazoles. Eur. J. Org. Chem. 2018, 2018, 4197-4201. [CrossRef]

18. Ahn, S.; Hong, M.; Sundararajan, M.; Ess, D.H.; Baik, M.-H. Design and optimization of catalysts based on mechanistic insights derived from quantum chemical reaction modeling. Chem. Rev. 2019, 119, 6509-6560. [CrossRef]

19. Chen, K.; Shi, G.; Zhang, W.; Li, H.; Wang, C. Computer-assisted design of ionic liquids for efficient synthesis of 3(2h)-furanones: A domino reaction triggered by $\mathrm{CO}_{2}$. J. Am. Chem. Soc. 2016, 138, 14198-14201. [CrossRef]

20. Sorokin, V.I. Copper(I) catalyzed N-arylation of azoles, the recent developments. Mini-Rev. Org. Chem. 2008, 5, 323-330. [CrossRef]

21. Monnier, F.; Taillefer, M. Catalytic C-C, C-N, and C-O Ullmann-type coupling reactions. Angew. Chem. Int. Ed. 2009, 48, 6954-6971. [CrossRef]

22. Beletskaya, I.P.; Cheprakov, A.V. The complementary competitors: Palladium and copper in C-N cross-coupling reactions. Organometallics 2012, 31, 7753-7808. [CrossRef]

23. Bariwal, J.; Van der Eycken, E. C-N bond forming cross-coupling reactions: An overview. Chem. Soc. Rev. 2013, 42, 9283-9303. [CrossRef]

24. Monnier, F.; Taillefer, M. Copper-catalyzed C(aryl)-N bond formation. Top. Organomet. Chem. 2013, 46, 173-204. [CrossRef]

25. Sambiagio, C.; Marsden, S.P.; Blacker, A.J.; McGowan, P.C. Copper catalysed Ullmann type chemistry: From mechanistic aspects to modern development. Chem. Soc. Rev. 2014, 43, 3525-3550. [CrossRef] [PubMed]

26. Yong, F.-F.; Azri, M.; Darrell Lim, Y.-E.; Teo, Y.-C. Efficient copper-catalyzed cross-coupling of nitrogen nucleophiles with N,Ndibenzyl-4-iodobenzenesulfonamide and its application in the synthesis of celecoxib intermediate. Tetrahedron 2020, 76, 131680. [CrossRef]

27. Zhu, R.; Xing, L.; Wang, X.; Cheng, C.; Su, D.; Hu, Y. Highly practical "ligand-free-like" copper-catalyzed N-arylation of azoles in lower nitrile solvents. Adv. Synth. Catal. 2008, 350, 1253-1257. [CrossRef]

28. Hong, C.S.; Seo, J.Y.; Yum, E.K. N-arylation of azaindoles in LiCl-mediated catalytic CuI reactions. Tetrahedron Lett. 2007, 48, 4831-4833. [CrossRef]

29. Antilla, J.C.; Baskin, J.M.; Barder, T.E.; Buchwald, S.L. Copper-diamine-catalyzed N-arylation of pyrroles, pyrazoles, indazoles, imidazoles, and triazoles. J. Org. Chem. 2004, 69, 5578-5587. [CrossRef]

30. Teo, Y.-C.; Yong, F.-F.; Sim, S. Ligand-free $\mathrm{Cu}_{2} \mathrm{O}$-catalyzed cross coupling of nitrogen heterocycles with iodopyridines. Tetrahedron 2013, 69, 7279-7284. [CrossRef]

31. Kwon, J.K.; Cho, J.H.; Ryu, Y.-S.; Oh, S.H.; Yum, E.K. N-arylation of carbazole by microwave-assisted ligand-free catalytic CuI reaction. Tetrahedron 2011, 67, 4820-4825. [CrossRef]

32. Kadari, L.; Erb, W.; Roisnel, T.; Radha Krishna, P.; Mongin, F. Iodoferrocene as a partner in N-arylation of amides. New J. Chem. 2020, 44, 15928-15941. [CrossRef]

33. Kadari, L.; Erb, W.; Halauko, Y.S.; Ivashkevich, O.A.; Matulis, V.E.; Lyakhov, D.; Roisnel, T.; Radha Krishna, P.; Mongin, F. On the $\mathrm{N}$-arylation of acetamide using 2-, 3- and 1'-substituted iodoferrocenes. Eur. J. Inorg. Chem. 2021, 2021, 377-391. [CrossRef]

34. Desarbre, E.; Coudret, S.; Meheust, C.; Mérour, J.-Y. Synthesis of 2-substituted-1H-pyrrolo[2,3-b]pyridines: Preparation of 7-azaolivacine analog and 7-azaindolopyridopyrimidine derivatives. Tetrahedron 1997, 53, 3637-3648. [CrossRef]

35. Slocum, D.W.; Jennings, C.A. Directed metalation reactions. 6. Competition of substituents for ortho direction of metalation in substituted anisoles. J. Org. Chem. 1976, 41, 3653-3664. [CrossRef]

36. Naka, H.; Akagi, Y.; Yamada, K.; Imahori, T.; Kasahara, T.; Kondo, Y. Fluorous synthesis of yuehchukene by alpha-lithiation of perfluoroalkyl-tagged 1-(arylsulfonyl)indole with mesityllithium. Eur. J. Org. Chem. 2007, 2007, 4635-4637. [CrossRef]

37. Katritzky, A.R.; Akutagawa, K. Carbon dioxide: A reagent for simultaneous protection of nucleophilic centers and the activation of alternative locations to electrophilic attack. V. Activation of the 2-alkyl group of a 2-alkylindole toward proton loss and subsequent electrophilic substitution. J. Am. Chem. Soc. 1986, 108, 6808-6809. [CrossRef]

38. Curtis, N.R.; Kulagowski, J.J.; Leeson, P.D.; Ridgill, M.P.; Emms, F.; Freedman, S.B.; Patel, S.; Patel, S. Synthesis and SAR of 2- and 3-substituted 7-azaindoles as potential dopamine D4 ligands. Bioorg. Med. Chem. Lett. 1999, 9, 585-588. [CrossRef]

39. Hogan, M.; Cotter, J.; Claffey, J.; Gleeson, B.; Wallis, D.; O'Shea, D.; Tacke, M. Synthesis and cytotoxicity studies of new (dimethylamino)-functionalized and 7-azaindole-substituted 'titanocene' anticancer agents (7-azaindole $=1 \mathrm{H}$-pyrrolo[2,3b]pyridine). Helv. Chim. Acta 2008, 91, 1787-1797. [CrossRef] 
40. Heinrich, T.; Seenisamy, J.; Emmanuvel, L.; Kulkarni, S.S.; Bomke, J.; Rohdich, F.; Greiner, H.; Esdar, C.; Krier, M.; Graedler, U.; et al. Fragment-based discovery of new highly substituted $1 \mathrm{H}$-pyrrolo[2,3- $b]$ - and $3 \mathrm{H}$-imidazolo[4,5- $b]$-pyridines as focal adhesion kinase inhibitors. J. Med. Chem. 2013, 56, 1160-1170. [CrossRef]

41. Juchum, M.; Günther, M.; Döring, E.; Sievers-Engler, A.; Lämmerhofer, M.; Laufer, S. Trisubstituted imidazoles with a rigidized hinge binding motif act as single digit nm inhibitors of clinically relevant egfr 1858r/t790m and 1858r/t790m/c797s mutants: An example of target hopping. J. Med. Chem. 2017, 60, 4636-4656. [CrossRef]

42. L'Heureux, A.; Thibault, C.; Ruel, R. Synthesis of functionalized 7-azaindoles via directed ortho-metalations. Tetrahedron Lett. 2004, 45, 2317-2319. [CrossRef]

43. Schneider, C.; David, E.; Toutov, A.A.; Snieckus, V. In situ anionic shielding for regioselective metalation: Directed peri and iterative metalation routes to polyfunctionalized 7-azaindoles. Angew. Chem. Int. Ed. 2012, 51, 2722-2726. [CrossRef]

44. Dalziel, M.E.; Patel, J.J.; Kaye, M.K.; Cosman, J.L.; Kitching, M.O.; Snieckus, V. Regioselective functionalization of 7-azaindole by controlled annular isomerism: The directed metalation-group dance. Angew. Chem., Int. Ed. 2019, 58, 7313-7317. [CrossRef]

45. Zhao, S.-B.; Wang, R.-Y.; Wang, S. Intramolecular C-H activation directed self-assembly of an organoplatinum(II) molecular square. J. Am. Chem. Soc. 2007, 129, 3092-3093. [CrossRef] [PubMed]

46. Barberis, C.; Moorcroft, N.; Arendt, C.; Levit, M.; Moreno-Mazza, S.; Batchelor, J.; Mechin, I.; Majid, T. Discovery of N-substituted 7-azaindoles as PIM1 kinase inhibitors-Part I. Bioorg. Med. Chem. Lett. 2017, 27, 4730-4734. [CrossRef] [PubMed]

47. L'Helgoual'ch, J.M.; Seggio, A.; Chevallier, F.; Yonehara, M.; Jeanneau, E.; Uchiyama, M.; Mongin, F. Deprotonative metalation of five-membered aromatic heterocycles using mixed lithium-zinc species. J. Org. Chem. 2008, 73, 177-183. [CrossRef] [PubMed]

48. Snégaroff, K.; L'Helgoual'ch, J.-M.; Bentabed-Ababsa, G.; Nguyen, T.T.; Chevallier, F.; Yonehara, M.; Uchiyama, M.; Derdour, A.; Mongin, F. Deprotonative metalation of functionalized aromatics using mixed lithium-cadmium, lithium-indium, and lithium-zinc species. Chem. Eur. J. 2009, 15, 10280-10290. [CrossRef] [PubMed]

49. Akimoto, G.; Otsuka, M.; Takita, R.; Uchiyama, M.; Hedidi, M.; Bentabed-Ababsa, G.; Lassagne, F.; Erb, W.; Mongin, F. Deprotonative metalation of methoxy-substituted arenes using lithium 2,2,6,6-tetramethylpiperidide: Experimental and computational study. J. Org. Chem. 2018, 83, 13498-13506. [CrossRef] [PubMed]

50. García-Álvarez, P.; Mulvey, R.E.; Parkinson, J.A. "LiZn(TMP) 3 ”, a zincate or a turbo-lithium amide reagent? Dosy NMR spectroscopic evidence. Angew. Chem. Int. Ed. 2011, 50, 9668-9671. [CrossRef]

51. Mokhtari Brikci-Nigassa, N.; Bentabed-Ababsa, G.; Erb, W.; Mongin, F. In situ 'trans-metal trapping': An efficient way to extend the scope of aromatic deprotometalation. Synthesis 2018, 50, 3615-3633. [CrossRef]

52. Ameur Messaoud, M.Y.; Bentabed-Ababsa, G.; Hedidi, M.; Derdour, A.; Chevallier, F.; Halauko, Y.S.; Ivashkevich, O.A.; Matulis, V.E.; Picot, L.; Thiéry, V.; et al. Deproto-metalation of N-arylated pyrroles and indoles using a mixed lithium-zinc base and regioselectivity-computed $\mathrm{CH}$ acidity relationship. Beilstein J. Org. Chem. 2015, 11, 1475-1485. [CrossRef]

53. Snégaroff, K.; Nguyen, T.T.; Marquise, N.; Halauko, Y.S.; Harford, P.J.; Roisnel, T.; Matulis, V.E.; Ivashkevich, O.A.; Chevallier, F.; Wheatley, A.E.H.; et al. Deprotonative metalation of chloro- and bromopyridines using amido-based bimetallic species and regioselectivity-computed CH acidity relationships. Chem. Eur. J. 2011, 17, 13284-13297. [CrossRef] [PubMed]

54. Fraser, R.R.; Mansour, T.S.; Savard, S. Acidity measurements in THF. V. Heteroaromatic compounds containing 5-membered rings. Can. J. Chem. 1985, 63, 3505-3509. [CrossRef]

55. Nagaradja, E.; Chevallier, F.; Roisnel, T.; Dorcet, V.; Halauko, Y.S.; Ivashkevich, O.A.; Matulis, V.E.; Mongin, F. Deproto-metallation using a mixed lithium-zinc base and computed $\mathrm{CH}$ acidity of 1-aryl 1H-benzotriazoles and 1-aryl 1H-indazoles. Org. Biomol. Chem. 2014, 12, 1475-1487. [CrossRef] [PubMed]

56. Gros, P.; Choppin, S.; Fort, Y. Lithiation of 2-chloro- and 2-methoxypyridine with lithium dialkylamides: Initial ortho-direction or subsequent lithium ortho-stabilization? J. Org. Chem. 2003, 68, 2243-2247. [CrossRef] [PubMed]

57. Chevallier, F.; Halauko, Y.S.; Pecceu, C.; Nassar, I.F.; Dam, T.U.; Roisnel, T.; Matulis, V.E.; Ivashkevich, O.A.; Mongin, F. N-aryl pyrazoles: DFT calculations of $\mathrm{CH}$ acidity and deprotonative metallation using a combination of lithium and zinc amides. Org. Biomol. Chem. 2011, 9, 4671-4684. [CrossRef]

58. Cavallo, G.; Metrangolo, P.; Milani, R.; Pilati, T.; Priimagi, A.; Resnati, G.; Terraneo, G. The halogen bond. Chem. Rev. 2016, 116, 2478-2601. [CrossRef]

59. Tilly, D.; Chevallier, F.; Mongin, F. Synthesis of heterobiaryls featuring 1,4 N . . S inter-ring interactions. Synthesis 2016, 48, 184-199. [CrossRef]

60. Merkul, E.; Schäfer, E.; Müller, T.J.J. Rapid synthesis of bis(hetero)aryls by one-pot Masuda borylation-suzuki coupling sequence and its application to concise total syntheses of meridianins A and G. Org. Biomol. Chem. 2011, 9, 3139-3141. [CrossRef]

61. Koller, M.; Carcache, D.A.; Orain, D.; Ertl, P.; Behnke, D.; Desrayaud, S.; Laue, G.; Vranesic, I. Discovery of 1H-pyrrolo[2,3c]pyridine-7-carboxamides as novel, allosteric mGluR5 antagonists. Bioorg. Med. Chem. Lett. 2012, 22, 6454-6459. [CrossRef]

62. Hong, S.; Kim, J.; Seo, J.H.; Jung, K.H.; Hong, S.-S.; Hong, S. Design, synthesis, and evaluation of 3,5-disubstituted 7-azaindoles as Trk inhibitors with anticancer and antiangiogenic activities. J. Med. Chem. 2012, 55, 5337-5349. [CrossRef]

63. Kannaboina, P.; Anilkumar, K.; Aravinda, S.; Vishwakarma, R.A.; Das, P. Direct C-2 arylation of 7-azaindoles: Chemoselective access to multiarylated derivatives. Org. Lett. 2013, 15, 5718-5721. [CrossRef] [PubMed]

64. Cardoza, S.; Das, P.; Tandon, V. Pd-catalyzed sequential arylation of 7-azaindoles: Aggregate-induced emission of tetra-aryl 7-azaindoles. J. Org. Chem. 2019, 84, 14015-14029. [CrossRef] 
65. Dar, M.O.; Bharatam, P.V.; Das, P.; Kukreti, S.; Tandon, V. Cu(II)-catalyzed sulfonylation of 7-azaindoles using DABSO as $\mathrm{SO}_{2}$-source and its mechanistic study. Tetrahedron 2020, 76, 131337. [CrossRef]

66. Qian, G.; Hong, X.; Liu, B.; Mao, H.; Xu, B. Rhodium-catalyzed regioselective C-H chlorination of 7-azaindoles using 1,2dichloroethane. Org. Lett. 2014, 16, 5294-5297. [CrossRef] [PubMed]

67. Begunov, R.S.; Sokolov, A.A.; Belova, V.O.; Solov'ev, M.E. Quantum chemical study of regioselectivity of reactions of substituted pyrido[1,2-a] benzimidazoles with electrophiles. Russ. Chem. Bull. 2016, 65, 644-647. [CrossRef]

68. Lassagne, F.; Sims, J.M.; Erb, W.; Mongin, O.; Richy, N.; El Osmani, N.; Fajloun, Z.; Picot, L.; Thiéry, V.; Robert, T.; et al. Thiazolo[5,4$f$ ]quinoxalines, oxazolo[5,4-f]quinoxalines and pyrazino $[b, e]$ isatins: Synthesis from 6-aminoquinoxalines and properties. Eur. $J$. Org. Chem. 2021, 2021, 2756-2763. [CrossRef]

69. Fukui, K.; Yonezawa, T.; Nagata, C.; Shingu, H. Molecular-orbital theory of orientation in aromatic, heteroaromatic, and other conjugated molecules. J. Chem. Phys. 1954, 22, 1433-1442. [CrossRef]

70. Carissan, Y.; Hagebaum-Reignier, D.; Goudard, N.; Humbel, S. Hückel-Lewis projection method: A "weights watcher" for mesomeric structures. J. Phys. Chem. A 2008, 112, 13256-13262. [CrossRef]

71. Carissan, Y.; Hagebaum-Reignier, D.; Goudard, N.; Humbel, S. HuLiS Program: Lewis-Embedded in Hückel Theory. Available online: http: / / www.hulis.free.fr (accessed on 25 March 2021).

72. Carissan, Y.; Hagebaum-Reignier, D.; Goudard, N.; Humbel, S. Weight Watchers électronique: Calculez votre poids de formes résonantes. L'Act. Chim. 2016, 406, 36-40.

73. Goudard, N.; Carissan, Y.; Hagebaum-Reignier, D.; Humbel, S. HuLiS 3.3.4. Available online: http://ism2.univ-amu.fr/hulis (accessed on 23 March 2021).

74. Hong, J.S.; Shim, H.S.; Kim, T.-J.; Kang, Y. (N-7-Azaindolyl)oligothiophenes: Synthesis, characterization, and photophysical properties. Tetrahedron 2007, 63, 8761-8769. [CrossRef]

75. Hedidi, M.; Bentabed-Ababsa, G.; Derdour, A.; Roisnel, T.; Dorcet, V.; Chevallier, F.; Picot, L.; Thiéry, V.; Mongin, F. Synthesis of $\mathrm{C}, \mathrm{N}^{\prime}$-linked bis-heterocycles using a deprotometalation-iodination- $\mathrm{N}$-arylation sequence and evaluation of their antiproliferative activity in melanoma cells. Bioorg. Med. Chem. 2014, 22, 3498-3507. [CrossRef]

76. Hedidi, M.; Erb, W.; Bentabed-Ababsa, G.; Chevallier, F.; Picot, L.; Thiery, V.; Bach, S.; Ruchaud, S.; Roisnel, T.; Dorcet, V.; et al. Synthesis of N-pyridyl azoles using a deprotometalation-iodolysis- $\mathrm{N}$-arylation sequence and evaluation of their antiproliferative activity in melanoma cells. Tetrahedron 2016, 72, 6467-6476. [CrossRef]

77. Amara, R.; Bentabed-Ababsa, G.; Hedidi, M.; Khoury, J.; Awad, H.; Nassar, E.; Roisnel, T.; Dorcet, V.; Chevallier, F.; Fajloun, Z.; et al. Synthesis of $\mathrm{N}$-aryl and $\mathrm{N}$-heteroaryl $\gamma_{-}, \delta$-, and $\varepsilon$-lactams using deprotometalation-iodination and $\mathrm{N}$-arylation, and properties thereof. Synthesis 2017, 49, 4500-4516. [CrossRef]

78. Hedidi, M.; Maillard, J.; Erb, W.; Lassagne, F.; Halauko, Y.S.; Ivashkevich, O.A.; Matulis, V.E.; Roisnel, T.; Dorcet, V.; Hamzé, M.; et al. Fused systems based on 2-aminopyrimidines: Synthesis combining deprotolithiation-in situ zincation with $\mathrm{N}$-arylation reactions and biological properties. Eur. J. Org. Chem. 2017, 2017, 5903-5915. [CrossRef]

79. Amara, R.; Awad, H.; Chaker, D.; Bentabed-Ababsa, G.; Lassagne, F.; Erb, W.; Chevallier, F.; Roisnel, T.; Dorcet, V.; Fajloun, Z.; et al. Conversion of isatins to tryptanthrins, heterocycles endowed with a myriad of bioactivities. Eur. J. Org. Chem. 2019, 2019, 5302-5312. [CrossRef]

80. Gottlieb, H.E.; Kotlyar, V.; Nudelman, A. NMR chemical shifts of common laboratory solvents as trace impurities. J. Org. Chem. 1997, 62, 7512-7515. [CrossRef]

81. Kjonaas, R.A.; Hoffer, R.K. Regiospecific 1,4-addition with Grignard-derived mixed triorganozincate reagents. J. Org. Chem. 1988, 53, 4133-4135. [CrossRef]

82. Altomare, A.; Burla, M.C.; Camalli, M.; Cascarano, G.L.; Giacovazzo, C.; Guagliardi, A.; Moliterni, A.G.G.; Polidori, G.; Spagna, R. SIR97: A new tool for crystal structure determination and refinement. J. Appl. Crystallogr. 1999, 32, 115-119. [CrossRef]

83. Sheldrick, G.M. A short history of SHELX. Acta Crystallogr. Sect. A Found. Crystallogr. 2008, 64, 112-122. [CrossRef] [PubMed]

84. Farrugia, L.J. WinGX and ORTEP for windows: An update. J. Appl. Crystallogr. 2012, 45, 849-854. [CrossRef]

85. Sheldrick, G.M. SHELXT-Integrated space-group and crystal-structure determination. Acta Crystallogr. Sect. A Found. Crystallogr. 2015, 71, 3-8. [CrossRef] [PubMed]

86. Sheldrick, G.M. Crystal structure refinement with shelxl. Acta Crystallogr. Sect. C Struct. Chem. 2015, 71, 3-8. [CrossRef] [PubMed]

87. Farrugia, L.J. ORTEP-3 for windows-A version of ORTEP-III with a graphical user interface (GUI). J. Appl. Crystallogr. 1997, 30, 565. [CrossRef]

88. Frisch, M.J.; Trucks, G.W.; Schlegel, H.B.; Scuseria, G.E.; Robb, M.A.; Cheeseman, J.R.; Scalmani, G.; Barone, V.; Mennucci, B.; Petersson, G.A.; et al. Gaussian 09; Revision A.02; Gaussian Inc.: Wallingford, CT, USA, 2009.

89. Cances, E.; Mennucci, B.; Tomasi, J. A new integral equation formalism for the polarizable continuum model: Theoretical background and applications to isotropic and anisotropic dielectrics. J. Chem. Phys. 1997, 107, 3032-3041. [CrossRef]

90. Hodgkinson, R.C.; Schulz, J.; Willis, M.C. Palladium-catalyzed tandem alkenyl- and aryl-C-N bond formation: A cascade $\mathrm{N}$-annulation route to 1-functionalized 7-azaindoles. Tetrahedron 2009, 65, 8940-8949. [CrossRef]

91. Phillips, D.P.; Zhu, X.-F.; Lau, T.L.; He, X.; Yang, K.; Liu, H. Copper-catalyzed C-N coupling of amides and nitrogen-containing heterocycles in the presence of cesium fluoride. Tetrahedron Lett. 2009, 50, 7293-7296. [CrossRef]

92. Pai, G.; Chattopadhyay, A.P. N-arylation of nitrogen containing heterocycles with aryl halides using copper nanoparticle catalytic system. Tetrahedron Lett. 2016, 57, 3140-3145. [CrossRef] 
93. Klapars, A.; Antilla, J.C.; Huang, X.; Buchwald, S.L. A general and efficient copper catalyst for the amidation of aryl halides and the N-arylation of nitrogen heterocycles. J. Am. Chem. Soc. 2001, 123, 7727-7729. [CrossRef]

94. Teo, Y.-C.; Yong, F.-F.; Lim, G.S. A manganese/copper bimetallic catalyst for C-N coupling reactions under mild conditions in water. Tetrahedron Lett. 2011, 52, 7171-7174. [CrossRef]

95. Wu, Q.; Lavigne, J.A.; Tao, Y.; D'Iorio, M.; Wang, S. Blue-luminescent/electroluminescent Zn(II) compounds of 7-azaindole and $\mathrm{N}$-(2-pyridyl)-7-azaindole: $\mathrm{Zn}(7 \text {-azaindole })_{2}\left(\mathrm{CH}_{3} \mathrm{COO}\right)_{2}, \mathrm{Zn}(\mathrm{NPA})\left(\mathrm{CH}_{3} \mathrm{COO}\right)_{2}$, and $\mathrm{Zn}(\mathrm{NPA})\left((\mathrm{S})-(+)-\mathrm{CH}_{3} \mathrm{CH}_{2} \mathrm{CH}_{(}\left(\mathrm{CH}_{3}\right) \mathrm{COO}\right)_{2}$ (NPA = N-(2-pyridyl)-7-azaindole). Inorg. Chem. 2000, 39, 5248-5254. [CrossRef] [PubMed]

96. Tani, K.; Sakurai, H.; Fujii, H.; Hirao, T. Synthesis of Re(I) complexes bearing tridentate 2,6-bis(7'-azaindolyl)phenyl ligand with green emission properties. J. Organomet. Chem. 2004, 689, 1665-1674. [CrossRef]

97. Lee, E.; Thirupathaiah, B.; Han, J.; Jung, D.; Kwon, G.; Kim, C.; Seo, S. Novel organic semiconductors based on phenyl and phenylthienyl derivatives for organic thin-film transistors. J. Nanosci. Nanotechnol. 2016, 16, 910-919. [CrossRef] 